\title{
Puha- és keményfás ligeterdők kapcsolata a Szigetközben
}

\author{
KEVEY Balázs \\ Pécsi Tudományegyetem, Ökológiai Tanszék \\ 7624 Pécs, Ifjúság u.6.; keveyb@gamma.ttk.pte.hu \\ Elfogadva: 2016. február 25.
}

Kulcsszavak: fehér nyár, Magyar Alföld, szüntaxonómia, tájvédelmi körzet.

Összefoglalás: A Duna-medencei ártéri ligeterdők szüntaxonómiai kapcsolatai többször is vita tárgyát képezték szakmai körökben. A legutóbb javasolt osztályozás alátámasztására 100, az északnyugat-magyarországi Szigetköz puha- és keményfás ligeterdeiben (Leucojo aestivi-Salicetum albae, Senecioni sarracenici-Populetum albae, Pimpinello majoris-Ulmetum populosum albae, Pimpinello majoris-Ulmetum typicum) gyüjtött felvételt elemeztem. A karakterfajok aránya, valamint a sokváltozós módszerekkel (cluster és fökoordináta-elemzés) nyert csoportosítások mutatják, hogy a három vizsgált társulás egyértelműen eltér egymástól, és alátámasztják azt az állítást, hogy a fehér nyár különböző társulásokban (pl. Senecioni sarracenici-Populetum albae és Pimpinello majorisUlmetum populosum albae) is állományalkotó faj lehet.

\section{Bevezetés}

Mint ismeretes, a hazai puhafás ligeterdeinket sokáig füz-nyár ligeterdőként Salicetum albae-fragilis néven tartottuk nyilván (vö. KÁRPÁTI I. 1957, 1958, 1979, 1982; KÁRPÁTI I. és KÁRPÁTI V. 1958c, 1969; KÁRPÁTI és TótH 1962a, 1962b; KovÁcs és KÁrPÁti 1973, 1974; SimON 1957; SimoN et al. 1993; Soó 1958, 1964, 1973, 1980 stb.). Később bizonyítást nyert, hogy e puhafás ligeterdők Magyarországon három asszociációt foglalnak magukba (vö. KEVEY 1993a, 1993b; KeVEy in Borhidi és KeVEy 1996; KeVEy 2008). Ezek egyike a Szigetközből leírt fehérnyár-liget (Senecioni sarracenici-Populetum albae KEvEY in BORHIDI et KEVEY 1996), amely később nemcsak a Duna-vidék egyéb tájain (Csepel-sziget: Kevey és Huszár 1999; Sárköz: Kevey ined., Mohácsi-sziget: Kevey ined.), hanem a Rába (Kevey ined.), a Dráva (Kevey 2008; Kevey és Tót H 2006) és a Mura mellől (KEvey 2014), valamint a Bodrogközben (vö. SzIrmaI et al. 2008; Kevey ined.) és a Felső-Tisza-vidéken (KEVEY et BARNA 2014) is elökerült. Vizsgálataim szerint e fehérnyár-ligetek jól elkülönültek a velük gyakran érintkező füzligetektől (Leucojo aestivi-Salicetum albae) és a feketenyár-ligetektől (Carduo crispi-Populetum nigrae). Publikációk ellenére még mindig úgy tűnik, 
hogy egyesek kételkednek e megállapításokban, ezért továbbra is a füz-nyár ligeterdőkről beszélnek, míg mások a fehérnyár-ligeteket a tölgy-kőris-szil ligetek fehér nyáras konszociációinak tekintik. E kételyek eloszlatása végett készítek egy összehasonlító tanulmányt, amelyben - a korábbiakhoz képest sokkal részletesebben - tisztázom e vegetációs egységek kapcsolatát.

\section{Anyag és módszer}

\section{Kutatási terület jellemzése}

Magyarország északnyugati részének ártéri tája a Szigetköz. A folyami hordalékot kavics képezi, amelyre a víz mozgási sebességétől függően helyenként durva vagy finom homok, másutt homokos iszap rakódik. A Duna és mellékágai mentén jól megfigyelhetők az ártéri szintek, amelyeken a hordalék minőségének megfelelően különböző fás társulások jöttek létre (vö. KEVEY 1993a, 1993b, 2008). Az alacsony ártér puhafás ligeterdei közül a mélyebben fekvő és iszapos talajú fehérfüz-ligeteket (Leucojo aestivi-Salicetum albae), valamint a mintegy 1-1,5 m-rel magasabb szinteken előforduló, homokos talajú fehérnyár-ligetek (Senecioni sarracenici-Populetum albae) összehasonlítását végeztem el. A vizsgálatba belevettem a magas ártér tölgy-kőris-szil ligeterdeit (Pimpinello majorisUlmetum), valamint e társulás fehér nyáras konszociációit is (Pimpinello majorisUlmetum populosum albae), hogy tisztázzam a puha- és a keményfás ligeterdők közötti kapcsolatot.

\section{Alkalmazott módszerek}

A cönológiai felvételek a Zürich-Montpellier növénycönológiai iskola (BECKING 1957; BRAUN-BLANQUET 1964) hagyományos kvadrátmódszerével készültek. A felvételek táblázatos összeállítása, valamint a karakterfajok csoportrészesedésének és csoporttömegének kiszámítása az „NS” számítógépes programcsomaggal (Kevey és Hirmann 2002) történt. A felvételkészítés és a hagyományos statisztikai számítások - kissé módosított - módszerét korábban részletesen közöltem (Kevey 2008). A SYN-TAX 2000 program (PODANI 2001) segítségével bináris cluster analízist (Method: Group average, Complete link; Coefficient: Baroni-Urbani et Buser) és ordinációt végeztem (Method: Principal coordinates analysis; Coefficient: Baroni-Urbani et Buser).

A fajok esetében KirÁly (2009), a társulásoknál pedig BoRHIDi és KEVEY (1996), KEVEY (2008), ill. BorHIDI et al. (2012), nómenklatúráját követem. A társulástani és a karakterfaj-statisztikai táblázatok felépítése az újabb eredmé- 
nyekkel (OBERDORFER 1992; MUCINA et al. 1993; BORHIDI et al. 2012; KeVEY 2008) módosított Soó (1980) féle cönológiai rendszerre épül. A növények cönoszisztematikai besorolásánál is elsősorban Soó (1964, 1966, 1968, 1970, 1973, 1980) Synopsis-ára támaszkodtam, de figyelembe vettem az újabb kutatási eredményeket is (vö. BoRHIDI 1993, 1995; HoRvÁTH et al. 1995; Kevey ined.).

\section{Eredmények}

Fiziognómia

Füzligetek és fehérnyár-ligetek közötti eltérések

A vizsgált puhafás ligeterdők fiziognómiáját tekintve lényeges különbségek mutatkoznak a lombkorona-, cserje- és gyepszintben egyaránt.

A füzligetek (Leucojo aestivi-Salicetum albae: KEVEY 2008: 19. táblázat) lombkoronáját elsősorban Salix alba, ritkán Salix fragilis, vagy e két fafaj elegyes aránya képezi. Egyéb fafajok (Alnus glutinosa, Populus nigra, Ulmus laevis) ritkák. A kifejlett állományok magassága legfeljebb 20-25 m. A fehérnyár-ligetek (Senecioni sarracenici-Populetum albae: KEVEY 2008: 22. táblázat) koronaszintjét főleg Populus alba alkotja, de mellette elegyesen egyéb fafajok (Populus nigra, Fraxinus excelsior, Quercus robur, Ulmus laevis) is előfordulhatnak. Az alsó lombkoronaszintben gyakori lehet az Alnus incana. Az idős állományokban a fák magassága $25-30 \mathrm{~m}$ is lehet.

A cserjeszint a tipikus füzligeteknél (Leucojo aestivi-Salicetum albae) hiányzik, illetve borítása legfeljebb 5\%-ot ér el, amit általában füz fajok (Salix alba, $S$. fragilis, S. purpurea, S. triandra, S. viminalis, S. cinerea) képeznek. Ezzel szemben a fehérnyár-ligetek (Senecioni sarracenici-Populetum albae) cserjeszintje általában fejlett, borítása gyakran eléri az 50-75\%-ot is. Elsősorban Cornus sanguinea képezi, amely közé egyéb cserjék is elegyedhetnek (pl. Crataegus monogyna, Euonymus europaeus, Sambucus nigra stb.).

A gyepszintben észlelt fiziognómiai különbségek közül a fáciesképző fajok emelendők ki. A füzligetekben (Leucojo aestivi-Salicetum albae) elsősorban mocsári és puhafaligeti növények fordulnak elő nagyobb tömegben (A-D: 3-5): Carex acuta, Galium palustre, Leucojum aestivum, Myosotis nemorosa, Persicaria dubia, P. hydropiper, Rorippa amphibia. A fehérnyár-ligetek (Senecioni sarracenici-Populetum albae) fáciesképző fajait egyrészt lomberdei növények (Lamium maculatum, Ranunculus ficaria), másrészt társulásközömbös (Glechoma hederacea, Rubus caesius, Urtica dioica), vagy idegenhonos özönnövények (Impatiens glandulifera, I. parviflora) képezik (5. táblázat). 
Fehérnyár-ligetek és tölgy-köris-szil ligetek fehér nyáras konszociációja közötti eltérések

A fehérnyár-ligetek (Senecioni sarracenici-Populetum albae: KEvEY 2008: 22. táblázat) és a tölgy-kőris-szil ligetek fehér nyáras konszociációjának (Pimpinello majoris-Ulmetum populosum albae: 1-2. táblázat) felső lombkoronaszintje között lényeges különbség nem látszik. A fehérnyár-ligeteknél lényegesen fejletlenebb az alsó lombkoronaszint, borítása legtöbbször csak 5-15\%, s csak ritkán érheti el a 30\%-ot. Ezzel szemben a tölgy-kőris-szil ligetek fehér nyáras konszociációja lényegesen fejlettebb alsó lombkoronaszinttel rendelkezik, borítása gyakran eléri a 40-50\%-ot. Benne jelentős szerepet játszik az Acer campestre, a Corylus avellana, a Fraxinus excelsior, a Padus avium és az Ulmus laevis, valamint az idegenhonos Juglans regia és a Robinia pseudo-acacia.

A cserjeszint és az újulat fejlettsége mindkét vegetációtípusnál hasonló, de a faji összetételük eléggé különböző. A fehérnyár-ligetek e szempontból lényegesen szegényebbek, míg a tölgy-kőris-szil ligetek fehér nyáras konszociációjának cserjeszintjében jelentős szerephez jutnak az alábbi fajok: Acer campestre, $A$. pseudo-platanus, Clematis vitalba, Corylus avellana, Fraxinus excelsior, Juglans regia, Ligustrum vulgare, Padus avium, Viburnum opulus.

A gyepszint fejlettsége is mindkét vegetációtípusnál hasonló, bár a tölgykőris-szil ligetek fehér nyáras konszociációjánál valamivel magasabbak a borítási viszonyok. Különbség jelentkezik azonban a fáciesképző fajok terén. Amíg a fehérnyár-ligetekre (Senecioni sarracenici-Populetum albae) a Lamium maculatum, a Ranunculus ficaria, a Glechoma hederacea, a Rubus caesius, az Urtica dioica, valamint az idegenhonos Impatiens glandulifera és I. parviflora fácies a jellemző, addig a tölgy-kőris-szil-ligetek fehér nyáras konszociációjában mezofil lomberdei (Fagetalia) növények töltik be ezt a szerepet: Aegopodium podagraria, Allium ursinum, Galium odoratum, Hedera helix, Parietaria officinalis (5. táblázat).

\section{Tölgy-köris-szil ligetek fehér nyáras és tipikus állományai közötti eltérések}

A tölgy-kőris-szil ligetek fehér nyáras (Pimpinello majoris-Ulmetum populosum albae: 1-2. táblázat) és tipikus (Pimpinello majoris-Ulmetum populosum albae typicum: 3-4. táblázat) állományai között a legszembetűnőbb különbség a lombkoronaszint megjelenése. Előbbiben ugyanis a Populus alba tömeges (A-D: 4-5) és konstans (K: V). Az alsó lombkoronaszintben továbbá az Alnus incana gyakoribb (K: III) előfordulása feltűnő. A cserjeszintben lényeges különbség nem látszik. A gyepszintben csupán néhány fáciesképző faj említhető meg. A felvételek alapján a Galium odoratum és a Parietaria officinalis fácies csak a tölgy-kőris-szil ligetek fehér nyáras konszociációiból, az Anemone ranunculoides, a Convallaria majalis, a Galanthus nivalis és a Polygonatum latifolium pedig csak a tipikus állományokból került elő (5. táblázat). 


\section{Fajkombináció}

Karakterfajok aránya

A puhafás ligeterdők karakterfajai (Salicetea purpureae s. 1.) a füzligetekben (Leucojo aestivi-Salicetum albae) a leggyakoribbak, majd arányuk a fehérnyárligeteken (Senecioni sarracenici-Populetum albae) át a tölgy-kőris-szil ligetekig (Pimpinello majoris-Ulmetum, incl. populosum albae) fokozatosan csökken (1. ábra; 6. táblázat). Még ennél is nagyobb csökkenő tendenciát mutatnak a mocsári (Phragmitetea s. 1.), a lápréti (Molinio-Juncetea s. 1.), valamint a nedves (Bidentetea s. 1.) és nyirkos (Galio-Urticetea s. 1.) élőhelyek ruderális elemei (5-8. ábra; 6. táblázat). A mezofil (Querco-Fagetea, Fagetalia) és xerofil (Quercetea pubescentis-petraeae) jellegű fajok aránya ezzel szemben emelkedő tendenciát mutat (2-4. ábra; 6. táblázat).

\section{Sokváltozós statisztikai elemzések eredményei}

Fenti hagyományos statisztikai számítások mellett néhány sokváltozós elemzést is végeztem. A dendrogramokon (9-10. ábra) és az ordinációs diagramon (11. ábra) látszik, hogy a felvételek három jól elkülönülő csoportot alkotnak: füzligetek (Leucojo aestivi-Salicetum albae), fehérnyár-ligetek (Senecioni sarracenici-Populetum albae) és tölgy-kőris-szil ligetek (Pimpinello majorisUlmetum). Utóbbin belül a tipikus és a fehér nyáras (populosum albae) állományok nem különülnek el egymástól.

\section{Megvitatás}

Fűzligetek és fehérnyár-ligetek kapcsolata

A mediterrán régió fehérnyár-ligeteit már régóta „Populetum albae (Br.Bl. 1930) Tchou 1946" néven ismerik (vö. Tchou 1949a, 1949b, 1949c, 1949d; KÁRPÁTI és KÁRPÁTI (1961). A szerbiai Vajdaság fehérnyár-ligetei már más jellegüek, melyekre SLAVNić (1952) a „Populetum nigro-albae”, majd PARABUćs KI (1972) a „Crataego nigrae-Populetum albae” nevet használja (utóbbi az előbbi szinonimja). A Duna ausztriai szakaszáról először SAUberer (1942), KNAPP (1944), Wendelberger-Zelinka (1952), Wendelberger G. (1955), StockHAMMER (1964), majd újabb kutatók sora (JELEM 1972, 1974; MARGL 1972, 1973; Plattner 1986; Fink et al. 1987; Straka 1992; Mucina et al. 1993; MiLETICH 1996; Ess 1999) ismerte el a fehérnyár-ligetek - mint önálló asszociáció - létezését. JURKo (1958) egyrészt a szlovákiai Csallóközben végzett kutatásai, másrészt pedig az ausztriai eredmények alapján a - Nyugat-Európában azóta is elfogadott - „Fraxino-Populetum albae” nevet vezette be a szakirodalomba. Ezt 
az asszociációt később az Elba csehországi szakaszáról is sikerült kimutatni (vö. Dovolilová-Novotná 1961; Moravec et al. 1982).

Magyarországon elöször Тóтн (1958) elemezte külön a füzligeteket, a fehérnyár-ligeteket és a tölgy-kőris-szil ligeteket. A hazai cönológiai irodalom erről azonban nem vett tudomást, $s$ a fehérnyár alkotta erdőket csak a tölgykőris-szil ligetek populosum albae nevü konszociációjaként tartották nyilván (vö. KÁrpáti És KÁrpáti 1958a, 1958b; Kárpáti és Tóth 1962a, 1962b; Soó 1958, 1964). Magam a füz-nyár ligeterdőként (Salicetum albae-fragilis Soó 1958) nyilvántartott - puhafás ligeteket előbb két (KeVEY 1993a, 1993b), majd három (BORHIDI et KEVEY 1996) asszociációra bontottam. Kutatásaim szerint a fehérnyár-ligetek (Senecioni sarracenici-Populetum albae) nálunk nemcsak a Duna (Kevey 1993a, 1993b, 2008; Kevey et Huszár 1999) és a Dráva (Kevey és Tóth 2006), hanem a Mura (Kevey 2014), a Rába (Kevey ined.), a Tisza (KEVEY et BARNA 2014) és a Maros (Kevey ined.) hullámterében is elkülöníthetők a mélyebben fekvő füzligetektől (Leucojo aestivi-Salicetum albae). Ezt az elkülönítést azonban több tényező is nehezíti. Egyrészt a Tisza hullámtere a legtöbb helyen viszonylag keskeny, ezért sok helyen nincs elegendö tér a tipikus puhafás asszociációk kialakulására. Másrészt a Tisza árterén tért hódító nemes nyár (Populus $\times$ euramericana) ültetvények miatt a természetszerü puhafás ligeterdők parányi állományokká zsugorodtak. Végül a fehérnyár-ligetek nagyobb része a vízügyi fennhatóság alatt álló - árvízvédelmi töltéseket szegélyező - erdőrészekben maradtak meg, ahol a nemes nyárak telepítése nem szerepel az elsődleges feladatok között, viszont az ilyen állományokat kubikgödrök sokasága szabdalja szét. A kubikgödrök alján a füzligetek (Leucojo aestiviSalicetum albae), azok magasabb peremén pedig a fehérnyár-ligetek (Senecioni sarracenici-Populetum albae) karakterfajai fordulnak elö. Felületes megfigyelésre úgy tűnik, mintha a Tisza mentén nem különülne el a két asszociáció. Sajnos a „Magyarország élőhelyei” c. könyv ide vonatkozó része (KEVEY et al. 2011) is azt írja a Tisza puhafás ligeterdeiről, hogy „a füz (S. alba, S. fragilis, $S . \times$ rubens) és a nyár (P. alba, $P . \times$ canescens, $P$. nigra) fajok gyakran közel azonos arányban alkotnak erdőt", ezért - a füzligetek, a fekete nyáras és a fehér nyáras ligeterdők mellett - egy negyedik alegységnek tünteti fel. E gondolat valamely társszerzőmtől származik, és az olvasó számára megtévesztő, holott a Tisza mentén ugyanúgy elkülönül a két asszociáció (KEVEY és BARNA 2014), mint másutt, legfeljebb az állományok fragmentáltsága, degradáltsága és egyéb hullámtéri bolygatások miatt a legtöbb helyen ma már nehezen ismerhetők fel.

Előbb láttuk, hogy a füzligetek (Leucojo aestivi-Salicetum albae) és a fehérnyár-ligetek (Senecioni sarracenici-Populetum albae) között milyen jelentős fiziognómiai különbségek mutatkoznak. A két puhafás ligeterdő társulás különválását a karakterfajok eltérő aránya is igazolja. A Salicetea purpureae s. 1., Phragmitetea 


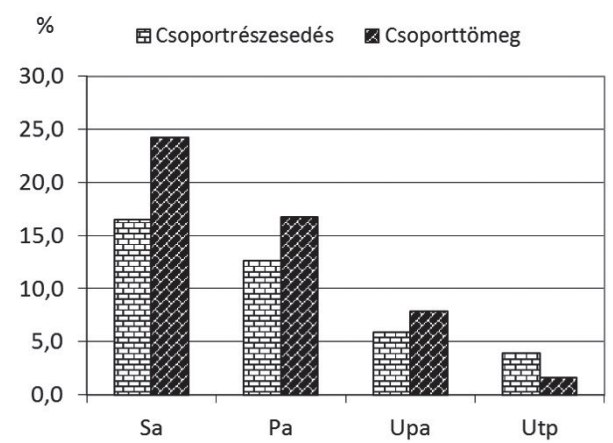

1. ábra. Salicetea purpureae s. 1. fajok aránya. Rövidítések lábjegyzetben*.

Fig. 1. Proportion of species characteristic of Salicetea purpureae s. l. Abbreviations in footnote*.

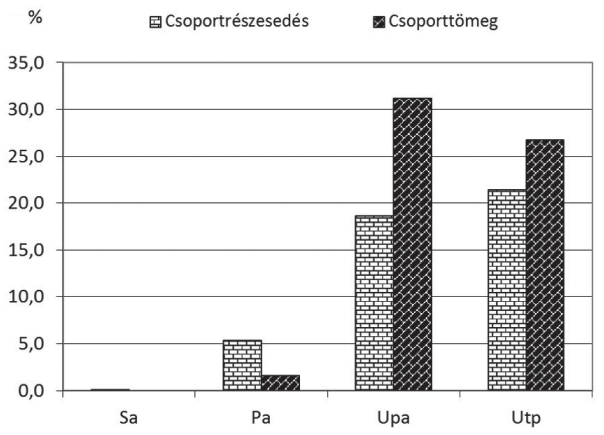

3. ábra. Fagetalia fajok aránya. Rövidítések az 1. ábra szerint.

Fig. 3. Proportion of species characteristic of Fagetalia. For abbreviations see Fig. 1.

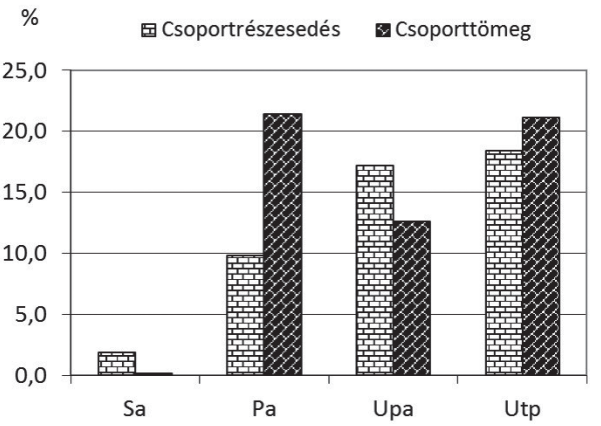

2. ábra. Querco-Fagetea fajok aránya. Rövidítések az 1. ábra szerint.

Fig. 2. Proportion of species characteristic of Querco-Fagetea. For abbreviations see Fig. 1.

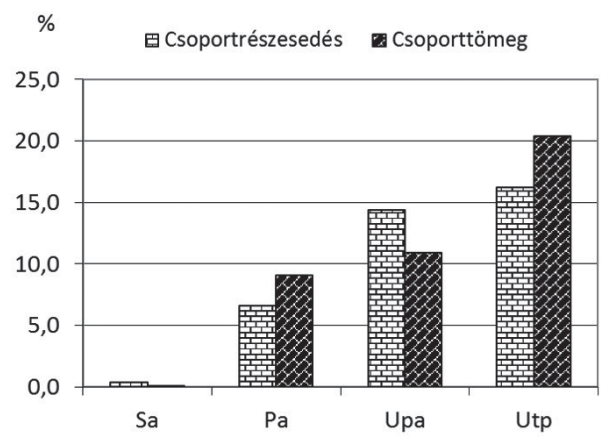

4. ábra. Quercetea pubescentis-petraeae fajok aránya. Rövidítések az 1. ábra szerint.

Fig. 4. Proportion of species characteristic of Quercetea pubescentis-petraeae. For abbreviations see Fig. 1.

s. 1., a Molinio-Juncetea s. 1. és a Bidentetea s. 1. elemek a füzligetekben, a QuercoFagetea, a Fagetalia és a Quercetea pubescentis-petraeae jellegü fajok pedig a fehér nyáras ligeterdőkben mutatnak lényegesen nagyobb gyakoriságot (6. táblázat; 1-7. ábra*). Ezen elemzési eredményeket a differenciális fajok magas száma is megerősíti (7. táblázat). A sokváltozós analízisek szerint a dendrogramokon

* Sa: Leucojo aestivi-Salicetum albae, Szigetköz (Kever 2008: 25 felv.); Pa: Senecioni sarraceniciPopuletum albae, Szigetköz (Kever 2008: 25 felv.); Upa: Pimpinello majoris-Ulmetum populosum albae, Szigetköz (Kever 2008: 4 felv.; Kevey ined.: 21 felv.); Utp: Pimpinello majoris-Ulmetum typicum, Szigetköz (Kever 2008: 15 felv.; Kevey ined.: 10 felv.). 
Kevey B.

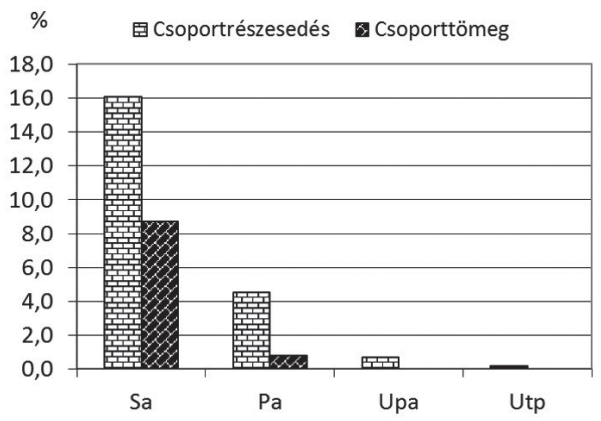

5. ábra. Phragmitetea s. 1. fajok aránya. Rövidítések az 1. ábra szerint.

Fig. 5. Proportion of species characteristic of Phragmitetea s. 1. For abbreviations see Fig. 1.

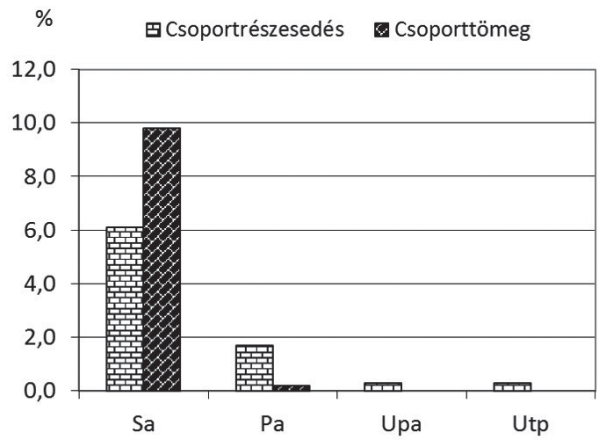

7. ábra. Bidentetea s. 1. elemek aránya. Rövidítések az 1. ábra szerint.

Fig. 7. Proportion of species characteristic of Bidentetea s. 1. For abbreviations see Fig. 1.

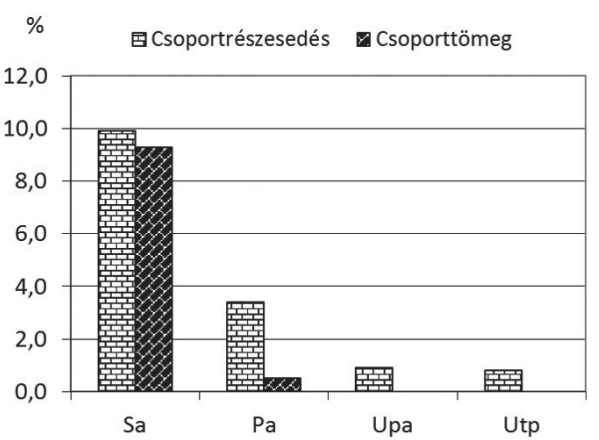

6. ábra. Molinio-Juncetea s. 1. elemek aránya. Rövidítések az 1. ábra szerint.

Fig. 6. Proportion of species characteristic of Molinio-Juncetea s. 1. For abbreviations see Fig. 1.

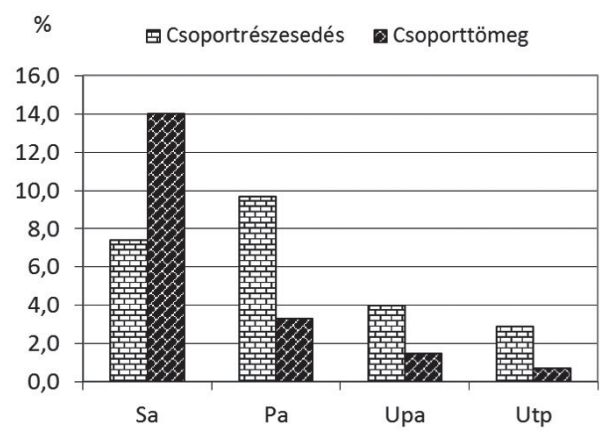

8. ábra. Galio-Urticetea s. 1. elemek aránya. Rövidítések az 1 . ábra szerint.

Fig. 8. Proportion of species characteristic of Galio-Urticetea s. 1. For abbreviations see Fig. 1.

(9-10. ábra) és az ordinációs diagramon (11. ábra) a füzligetek és a fehérnyár-ligetek igen élesen elkülönülnek, amely azt igazolja, hogy e két különböző felvételi anyag valójában két külön asszociációt képez.

Fehérnyár-ligetek és tölgy-kőris-szil ligetek fehér nyáras konszociációjának kapcsolata

A fehérnyár-ligetek (Senecio sarracenici-Populetum albae) és a tölgy-kőrisszil ligetek (Pimpinello majoris-Ulmetum) közötti kapcsolat kérdése azért tisztázandó, mert utóbbi asszociációnak van egy Populus alba-s konszociációja 
(vö. KÁRPÁti 1985; KÁRPÁTI és KÁRPÁTI V. 1958a, 1958b; KÁRPÁTi és TótH 1962a, 1962b; Soó 1958, 1964). Ezzel kapcsolatban felmerül az a kérdés, hogy a fehér nyáras ligeterdők azonosíthatók-e a tölgy-kőris-szil ligetek fehér nyáras konszociációival, vagy sem?

Előbb láttuk, hogy a fehérnyár-ligetek (Senecioni sarracenici-Populetum albae) és a tölgy-kőris-szil ligetek fehér nyáras konszociációja (Pimpinello majoris-Ulmetum populosum albae) között fiziognómiai különbségek mutathatók ki, elsősorban az alsó lombkoronaszintben, a cserjeszintben és a gyepszintben, bár e különbségek kevésbé feltűnőek, mert a felső lombkoronaszint mindkét vegetációs egységnél azonos. Sokkal nagyobb eltérés mutatkozik viszont a karakterfajok arányában. E téren a Salicetea s. 1., a Phragmitetea s. 1., a MolinioJuncetea s. 1., a Bidentetea s. 1. és a Galio-Urticetea s. 1. elemek a fehér nyáras ligeterdőkben sokkal gyakoribbak, mint a tölgy-kőris-szil ligetek fehér nyáras konszociációiban (6. táblázat; 1. és 5-8. ábra). Ezzel szemben Fagetalia és a Quercetea pubescentis-petraeae jellegü fajok a tölgy-kőris-szil ligetek fehér nyáras konszociációiban játszanak lényegesen nagyobb szerepet (6. táblázat; 3-4. ábra). A két felvételi anyag közötti különbséget a differenciális fajok magas száma is igazolja (8. táblázat). A legfeltűnőbb különbségeket azonban a sokváltozós elemzések mutatják. A dendrogramokon (9-10. ábra) és az ordinációs diagramon (11. ábra) a fehérnyár-ligetek és a tölgy-kőris-szil ligetek igen élesen elkülönülnek, de utóbbi asszociáció tipikus és fehér nyáras felvételei egyetlen csoportba különülnek. Mindez azt igazolja, hogy a fehérnyár-ligetek (Senecioni sarracenici-Populetum albae) nem azonosíthatók a tölgy-kőris-szil ligetek valóban létező fehér nyáras konszociációival (Pimpinello majoris-Ulmetum populosum albae), ezért azokat önálló asszociációként kezelhetjük (vö. KEVEY 1993a, 1993b, 2008). E fehérnyár-ligetek - főleg a Duna felsőbb szakaszain (Ausztria) és az Elba (Csehország) mentén - a természetes szukcesszió során jöttek létre, de síkon az árvízvédelmi töltések létesítésével a hullámtérben rekedt tölgykőris-szil ligetekből regresszív szukcesszió révén is kialakulhattak. (vö. KEVEY 1993a, 1993b).

Tölgy-kőris-szil ligetek fehér nyáras és tipikus állományainak kapcsolata

A tölgy-kőris-szil ligetek fehér nyáras konszociációi (Pimpinello majorisUlmetum populosum albae) a tipikus állományok tarra vágása után jönnek létre, amelyek egy idő után ismét tipikus tölgy-kőris-szil ligetekké regenerálódnak (vö. KÁrPÁti 1985; KÁrpáti és KÁrpáti 1958a, 1958b; KÁrpÁti és Tóth 1962a, 1962b; Soó 1958, 1964). Soó (1964) e fehér nyáras konszociációra a subass. populetosum albae elnevezést is használja. Az elemzési eredmények szerint a fehér nyáras állományok valamivel több higrofil elemet tartalmaznak, mint a ti- 


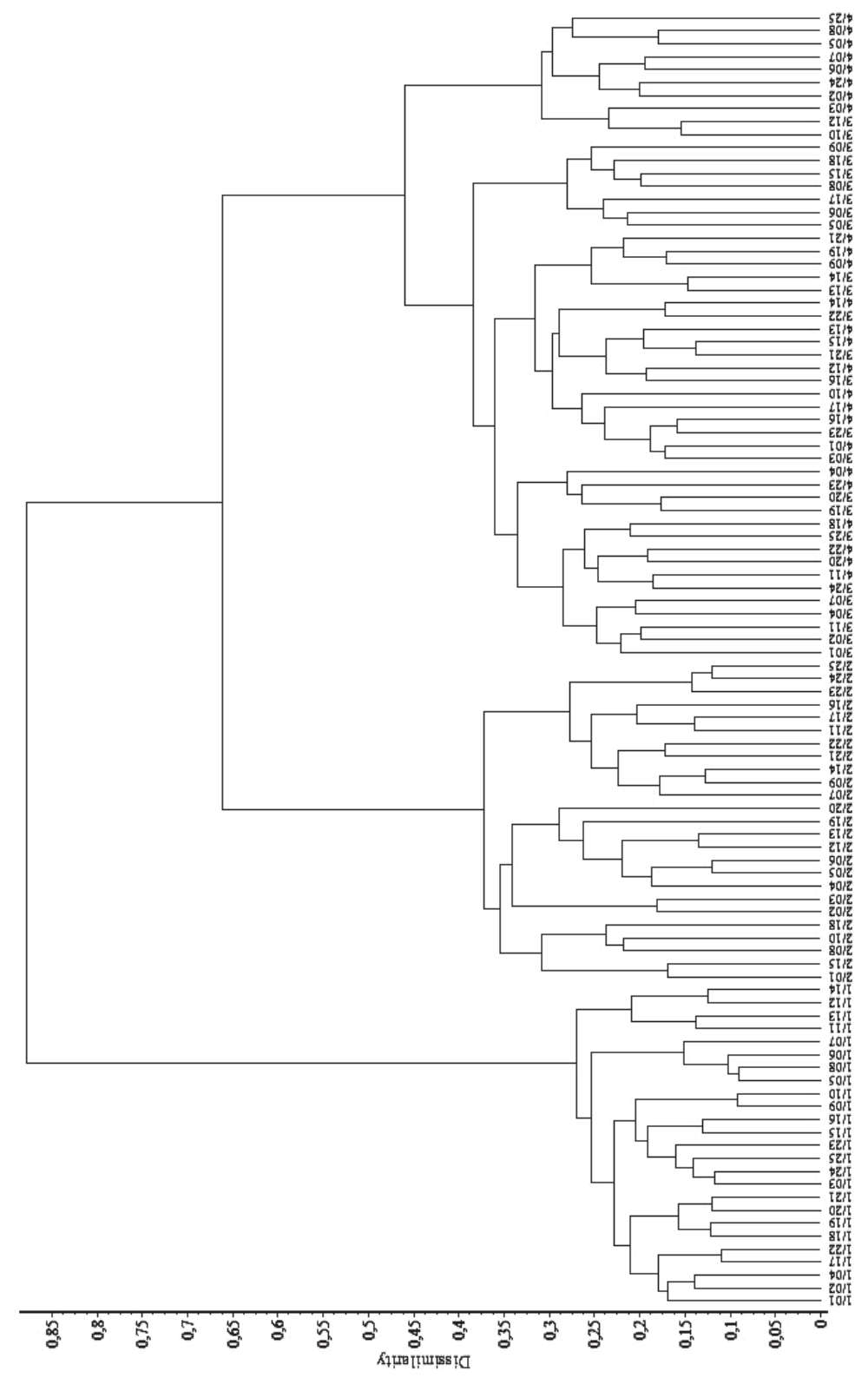

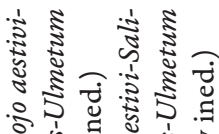

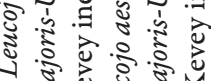

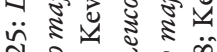
눙 - ฐ

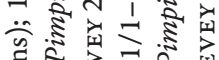

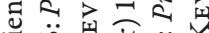
记这获 O के 号.

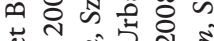

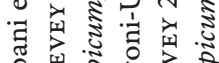

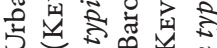
- N $^{\circ}$

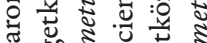
๑ 苛 心 ปิ ปี

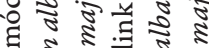
ป ई

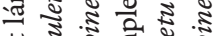
म ह

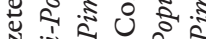
:

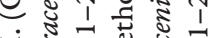

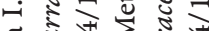

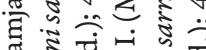
పี兀 ० \& च छे चै च : $1 \ddot{\circ} \Xi \ddot{\sim}$ 望

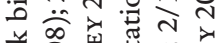

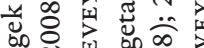

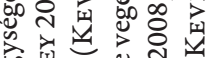
कू⿱

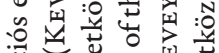

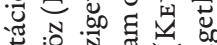

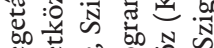
范 \& 0 : 0

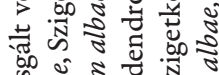

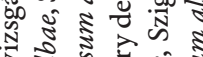

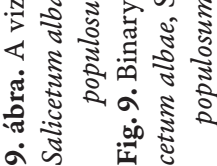




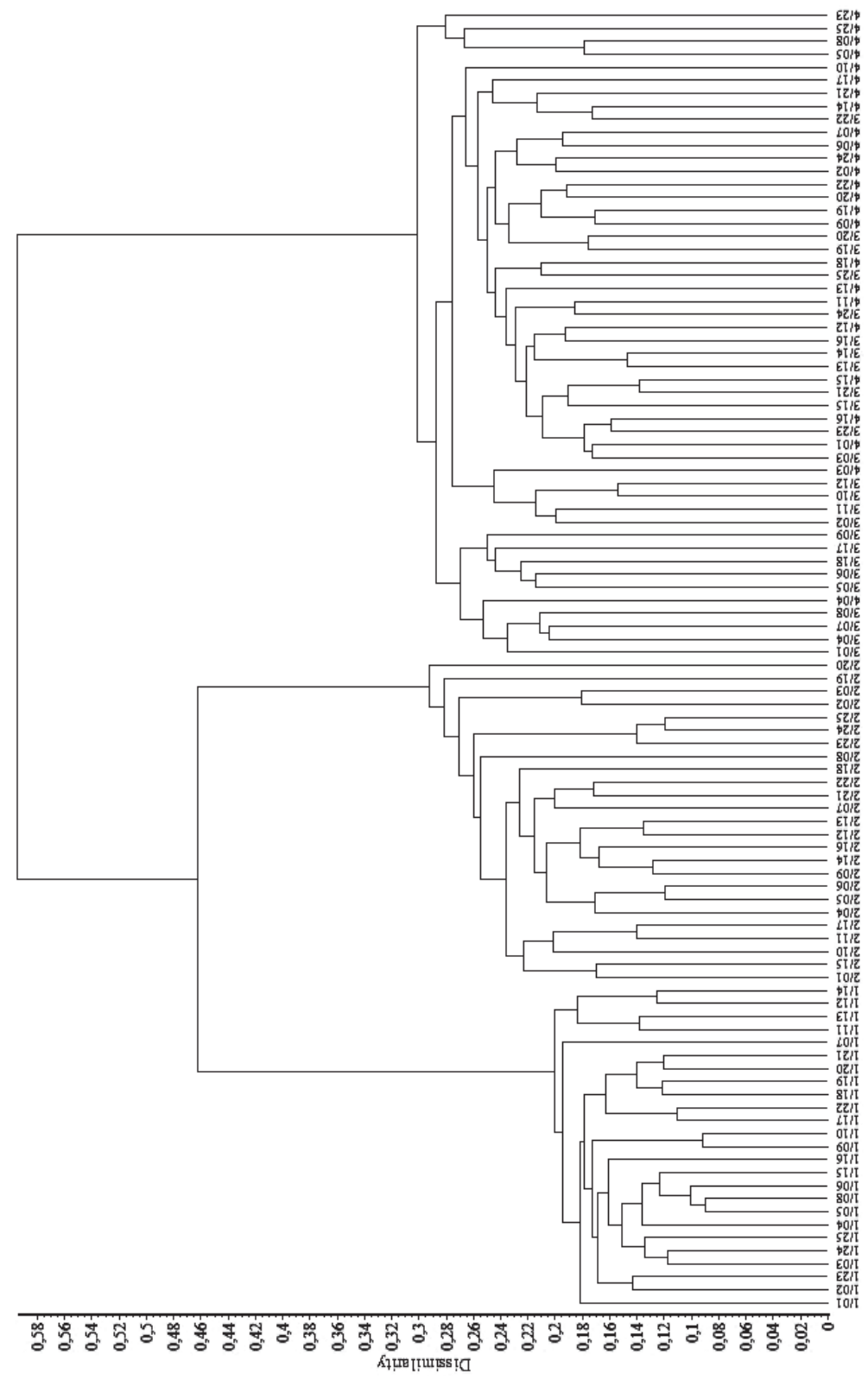

ชั

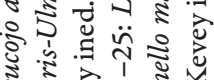

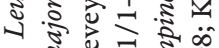
तิ

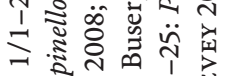

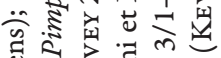

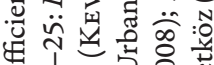

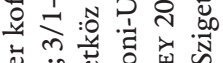

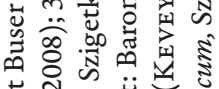
च त्र

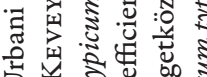
1

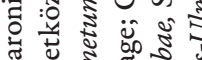

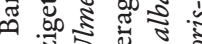
氙 \& 8 है ₹ कू है

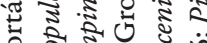

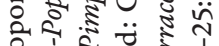

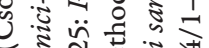
G 要

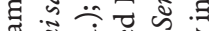

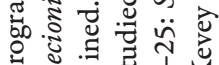

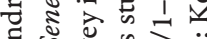
चี क तै

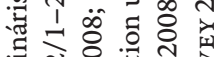
대에

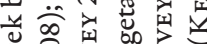

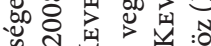

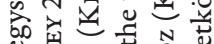
की

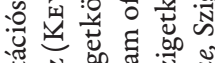

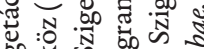

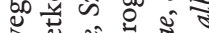

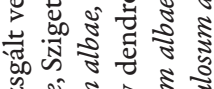
मूँ है है है है

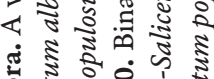
元芯

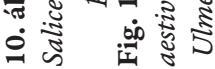




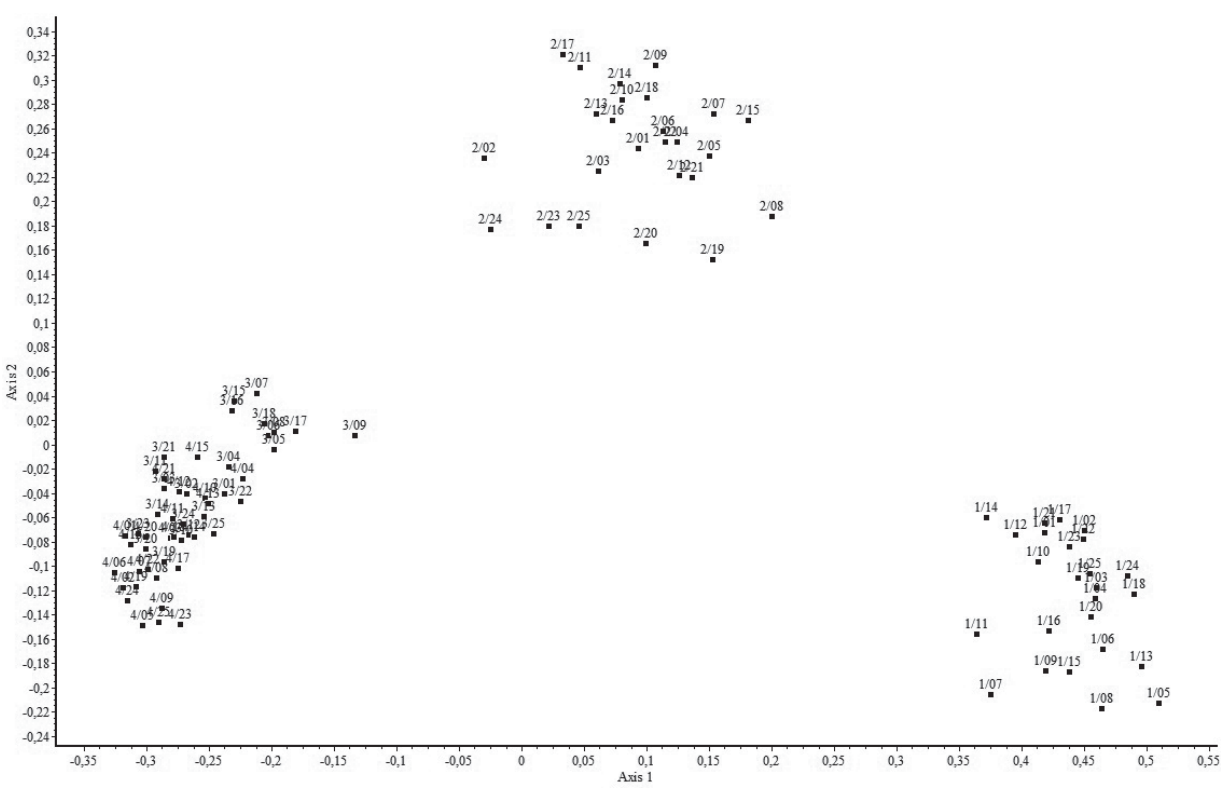

11. ábra. A vizsgált vegetációs egységek bináris ordinációs diagramja. (Főkoordináta-analízis, Baroni-Urbani et Buser kofficiens); 1/1-25: Leucojo aestivi-Salicetum albae, Szigetköz (KeveY 2008); 2/1-25: Senecioni sarracenici-Populetum albae, Szigetköz (Kevey 2008); 3/1-25: Pimpinello majoris-Ulmetum populosum albae, Szigetköz (Kevey 2008; Kevey ined.); 4/1-25: Pimpinello majoris-Ulmetum typicum, Szigetköz (KeVEy 2008; Kevey ined.)

Fig. 11. Binary ordination diagram of the vegetation units studied (Method: Principal coordinates analysis; Coefficient: Baroni-Urbani et Buser). 1/1-25: Leucojo aestivi-Salicetum albae, Szigetköz (Kevey 2008); 2/1-25: Senecioni sarracenici-Populetum albae, Szigetköz (Kevey 2008); 3/1-25: Pimpinello majoris-Ulmetum populosum albae, Szigetköz (Kevey 2008; Kevey ined.); 4/1-25: Pimpinello majoris-Ulmetum typicum, Szigetköz (Kevey 2008; Kevey ined.)

pikus állományok. Ennek oka elsősorban azzal hozható összefüggésbe, hogy a Szigetközben e fehér nyáras állományok legtöbbször közvetlenül szegélyezik a Mosoni-Dunát. Ez a kicsiny különbség azonban elhanyagolható. Mivel a tölgykőris-szil ligetek tipikus és fehér nyáras állományai között lényeges különbséget sem fiziognómiai szempontból, sem a karakterfajok arányában (6. táblázat, 1-8. ábra), sem a differenciális fajok számában (9. táblázat), sem pedig a sokváltozós elemzések (9-11. ábra) során nem sikerült kimutatni, a fehér nyáras állományokat nem ajánlatos szubasszociációnak tekinteni, helyesebb továbbra is a fehér nyáras konszociációról beszélni. Fent elhangzottak alapján a vizsgált négy vegetációs egység három asszociációba sorolható, amelyek cönoszisztematikai helye az alábbi módon vázolható. 
Divízió: Querco-Fagea Jakucs 1967

Osztály: Salicetea purpureae Moor 1958

Rend: Salicetalia purpureae Moor 1958

Csoport: Salicion albae Soó 1930 em. Th. Müller és Görs 1958

Alcsoport: Salicenion albae-fragilis Kevey 2008

Társulás: Leucojo aestivi-Salicetum albae Kevey in Borhidi et Kevey 1996

Alcsoport: Populenion nigro-albae Kevey 2008

Társulás: Senecioni sarracenici-Populetum albae Kevey in Borhidi et Kevey 1996

Osztály: Querco-Fagetea Br.-Bl. et Vlieger in Vliger 1937 emend. Borhidi in Borhidi et Kevey 1996

Rend: Fagetalia sylvaticae Pawłowski in Pawłowski et al. 1928

Csoport: Alnion incanae Pawłowski in Pawłowski et al. 1928

Alcsoport: Ulmenion Oberd. 1953

Társulás: Pimpinello majoris-Ulmetum Kevey in Borhidi et Kevey 1996

\section{Köszönetnyilvánítás}

Köszönetem illeti azon kollégákat, akik terepismeretükkel, kalauzolásukkal, vagy egyéb módon segítették munkámat: Alexay Zoltán, Belovitz Károly, Czimber Gyula†, Koltai Gábor, Werner Ervin.

\section{Rövidítések}

A1: felső lombkoronaszint; A2: alsó lombkoronaszint; AF: AremonioFagion; Agi: Alnenion glutinosae-incanae; Ai: Alnion incanae; Alo: Alopecurion pratensis; Aon: Alnion glutinosae; APa: Abieti-Piceea; $A Q$ : Aceri tatariciQuercion; AR: Agropyro-Rumicion crispi; Ar: Artemisietea; Ara: Arrhenatheretea; Ate: Alnetea glutinosae; B1: cserjeszint; B2: újulat; Bec: Beckmannion eruciformis; Ber: Berberidion; Bia: Bidentetea; Bin: Bidention tripartiti; Bra: Brometalia erecti; C: gyepszint; Cal: Calystegion sepium; Cau: Caucalidion platycarpos; CeF: Cephalanthero-Fagenion; Cgr: Caricenion gracilis; Che: Chenopodietea; ChS: Chenopodio-Scleranthea; Cp: Carpinenion betuli; Cyc: Cynosurion cristati; CyF: Cynodonto-Festucenion; Des: Deschampsion caespitosae; Epa: Epilobietea angustifolii; Epn: Epilobion angustifolii; F : Fagetalia sylvaticae; FB: Festuco-Bromea; FBt: Festuco-Brometea; FiC: Filipendulo-Cirsion oleracei; FPe: Festuco-Puccinellietea; FPi: Festuco-Puccinellietalia; Fru: Festucion rupicolae; Fvg: Festucetea vaginatae; Fvl: Festucetalia valesiacae; GA: Galio-Alliarion; HyL: Hydrochari-Lemnetea; ined.: ineditum (kiadatlan közlés); Le: Lemnion minoris; LeP: Lemno-Potamea; Mag: Magnocaricetalia; Moa: Molinietalia coeruleae; MoA: Molinio-Arrhenatherea; MoJ: Molinio-Juncetea; Nc: Nanocyperion flavescentis; 
NC: Nardo-Callunetea; NG: Nasturtio-Glycerietalia; OCn: Orno-Cotinion; Ona: Onopordetalia; Ory: Oryzetea sativae; Pea: Potametea; Pla: Plantaginetea; Pli: Phragmitetalia; Pna: Populenion nigro-albae; PQ: Pino-Quercetalia; Prf: Prunion fruticosae; Pru: Prunetalia spinosae; Pte: Phragmitetea; Qc: Quercetalia cerridis; QFt: Querco-Fagetea; Qpp: Quercetea pubescentis-petraeae; Qr: Quercetalia roboris; Qrp: Quercion robori-petraeae; S: summa (összeg); Sal: Salicion albae; SCn: Scheuchzerio-Caricetea nigrae; Sea: Secalietea; Sio: Sisymbrion officinalis; s. 1.: sensu lato (tágabb értelemben); Spu: Salicetea purpureae; TA: Tilio platyphyllaeAcerenion pseudoplatani; Ulm: Ulmenion; US: Urtico-Sambucetea.

\section{Irodalomjegyzék}

BeCKING, R. W. 1957: The Zürich-Montpellier School of phytosociology. Botanical Review 23: 411-488. http://dx.doi.org/10.1007/bf02872328

BoRHIDI A. 1993: A magyar flóra szociális magatartás típusai, természetességi és relatív ökológiai értékszámai. Janus Pannonius Tudományegyetem, Pécs, 95 pp.

BORHIDI A. 1995: Social behaviour types, the naturalness and relative ecological indicator values of the higher plants in the hungarian flora. Acta Botanica Academiae Scientiarum Hungaricae 39: 97-181.

Borhidi A., Kevey B. 1996: An annotated checklist of the Hungarian plant communities II. In: Borhidi A. (ed.) Critical revision of the Hungarian plant communities. Janus Pannonius University, Pécs, pp. 95-138.

Borhidi A., Kevey B., Lendvai G. 2012: Plant communities of Hungary. Akadémiai Kiadó, Budapest, $544 \mathrm{pp}$.

Braun-Blandeut J. 1964: Pflanzensoziologie (ed. 3.). Springer Verlag, Wien, New York, 865 pp.

Dovolilová-Novotná Z. 1961: Beitrag zur systematischen Stellung der Auengesellschaften. Preslia 33: 225-242.

EssL F. 1999: Terrestrische vegetation des Gießganges im Tullner Feld. Forschung im verbund Schriftenreihe 53: 99-216.

FINK M., KORNER I., WRB KA T. 1987: Ökologische Vorbehaltsflächen der rechtsufrigen Dunauauen im Raum Wien. ARGE für Naturschutzforschung und Angewandte Vegetationsökologie, Wien.

Horváth F., Dobolyi Z. K., Morschhauser T., Lökös L., Karas L., Szerdahelyi T. 1995: Flóra adatbázis 1.2. Vácrátót, 267 pp.

JAKUCS P. 1967: Gedanken zur höheren Systematik der europäischen Laubwälder. Contribuții Botanici Cluj 1967: 159-166.

Jelem H. 1972: Die Donauauen. In: Ehrendorfer F., Ni kLfeld H. (ed.) Naturgeschichte Wiens III. Forstliches, Karten. Jugend und Volk, Wien, pp. 45-72.

Jelem H. 1974: Die Auwälder der Donau in Österreich. Mitteilungen der Forstlichen Bundes-Versuchsanstalt Wien 109: 1-287.

JuRko A. 1958: Podne ekologické pomery a lesné spolocenstvá Podunajskej níziny. Slovenská Akadémia Vied, Bratislava, 225 pp.

KÁRPÁTI I. 1957: A hazai Duna-ártér erdei. Kandidátusi értekezés (kézirat).

KÁRPÁTI I. 1958: A hazai Duna-ártér erdei. Kandidátusi értekezés tételei, Budapest, 5 pp.

KÁRPÁTI I. 1979: Ligeterdei ökoszisztémák kutatása. MTA Veszprémi Akadémiai Bizottsága Monográfiái 5(10): 24-39. 
KÁRPÁTI I. 1982: Die Vegetation der Auen-Ökosysteme in Ungarn. Veröffentlichung der Internationalen Arbeitsgemeinschaft für Clusius-Forschung. Güssing 4: 1-24.

KÁRPÁTI I. 1985: Az ártéri szintek geomorfológiai- és vegetáció-szukcessziójának kapcsolata. In: FeKete G. (szerk.) A cönológiai szukcesszió kérdései. Biológiai Tanulmányok 12: 73-81.

KÁRPÁTI I., KÁRPÁTI V. 1958a: Elm-ash-oak grove forests (Querceto-Ulmetum hungaricum Soó) turning into white poplar dominated stands. Acta Agronomica Hungarica 8: 267-283.

KÁRPÁTI I., KÁRPÁTI V. 1958b: Az ártéri fehérnyárasok kialakulása és jelentősége. Erdőgazdaság és Faipar 1958(10): 14.

KÁRPÁTI I., KÁRPÁTI V. 1958c: A hazai Duna-ártér erdőtípusai. Az Erdő 7: 307-318.

KÁRpáti I., KÁRpáti V. 1961: Die zönologischen Verhältnisse der Auenwälder Albaniens. Acta Botanica Academiae Scientiarum Hungaricae 7: 235-297.

KÁRPÁTI I., KÁRPÁTI V. 1969: Die zönologischen Verhältnisse der Donauauenwälder Ungarns. Verhandlungen der Zoologisch-Botanischen Gesellschaft in Wien 108-109 (1968-1969): 165-179.

KÁrpáti I., Tóth I. 1962a: Die Auenwaldtypen Ungarns. Acta Agronomica Hungarica 11 (19611962): 421-452.

KÁRPÁTi I., Tóth I. 1962b: Az ártéri nyárasok erdőtípusai. In: KeResztesi B. (szerk.) A magyar nyárfatermesztés. Mezőgazdasági Kiadó, Budapest, pp. 150-168.

Kevey B. 1993a: A Szigetköz ligeterdeinek összehasonlító-cönológiai vizsgálata. Kandidátusi értekezés (kézirat). Janus Pannonius Tudományegyetem, Növénytani Tanszék, Pécs, 108 pp.

Kevey B. 1993b: A Szigetköz ligeterdeinek összehasonlító-cönológiai vizsgálata. Kandidátusi értekezés tézisei. Janus Pannonius Tudományegyetem, Növénytani Tanszék, Pécs, 9 pp.

Kevey B. 2008: Magyarország erdőtársulásai (Forest associations of Hungary). Tilia 14: 1-488.

Kevey B. 2014: A hazai Mura-ártér fehérnyár-ligetei (Senecioni sarracenici-Populetum albae Kevey in Borhidi et Kevey 1996). Kaposvári Rippl-Rónai Múzeum Közleményei 3: 29-56.

Kevey B., BARna Cs. 2014: A hazai Felső-Tisza-vidék fehérnyár-ligetei (Senecioni sarracenici-Populetum albae Kevey in Borhidi et Kevey 1996). Botanikai Közlemények 101: 105-143.

Kevey B., HirmanN A. 2002: „NS” számítógépes cönológiai programcsomag. In: Összefoglalók, Aktuális flóra- és vegetációkutatások a Kárpát-medencében V, Pécs, 2002. március 8-10, p. 74.

Kevey B., Huszár Zs. 1999: A Háros-sziget fehérnyár-ligetei (Senecioni sarracenici-Populetum albae Kevey in Borhidi et Kevey 1996). Természetvédelmi Közlemények 8: 37-48.

Kevey B., MolnÁr Zs., BöLÖNi J., BARTha D., TímÁr G., Horváth D. 2011: FüZ-nyár ártéri erdők. In: BöLÖNI J., MolnÁr Zs., Kun A. (szerk.) Magyarország élőhelyei. Vegetációtípusok leírása és határozója. ÁNÉR 2011. MTA Ökológiai és Botanikai Kutatóintézete, Vácrátót, pp. 242-246.

Kevey B., Tóth V. 2006: A Baranyai-Dráva-sík fehérnyár-ligetei (Senecioni sarracenici-Populetum albae Kevey in Borhidi et Kevey 1996). Natura Somogyiensis 9: 47-62.

KIrÁly G. (szerk.) 2009: Új magyar füvészkönyv. Magyarország hajtásos növényei. Határozókulcsok. Aggteleki Nemzeti Park Igazgatóság, Jósvafö, 616 pp.

KNAPP R. 1944: Vegetationsaufnahmen von Wäldern der Alpenostrand-Gebiete 6. Auen-und Quellwälder Als Manuskript vervielfältigt). Halle (Saale), 59 pp.

KovÁCs M., KÁRpáti I. 1973: Untersuchung über die Zonations- und Produktionsverhältnisse im Überschwemmungsgebiet der Drau I. Verlandung der toten Arme und die Zonationen des Bodens und der Vegetation im Inundationsgebiet der Drau. Acta Botanica Academiae Scientiarum Hungaricae 18: 323-353.

KovÁcs M., KÁRPÁTI I. 1974: A Mura- és a Dráva-ártér vegetációja. Földrajzi Értesítő 22: 21-32.

MARgl H. 1972: Die Ökologie der Donauauen und ihre naturnahen Waldgesellschaften. In: Ehrendorfer F., Kaltenbach A., Niklfeld H., Starmühlner F. (eds.) Naturgeschichte Wiens II. Naturnahe Landschaften, Pflanzen- und Tierwelt. Jugend und Volk, Wien, pp. 675-706. 
Kevey B.

MARgL H. 1973: Pflanzengesellschaften und ihre standortgebundene Verbreitung in teilweise abgedämmten Donauauen (Untere Lobau). Verhandlungen der Zoologisch-Botanischen Gesellschaft in Österreich, Wien 113:5-51 + Tab.

Miletich, D. 1996: Die Vegetation der Stopfenreuther Au und ihre standörtliche Differenzierung. Diplomarbeit, Universität Wien.

Moor, M. 1958: Die Pflanzengesellschaften schweizerischer Flußauen. Mitteilungen der Schweizerischen Anstalt für das Forstliche Versuchswesen 34: 221-360.

Moravec J., Husová M., Neuhäusl R., Neuhäuslová-Novotná Z. 1982: Die Assoziationen mesophiler und hygrophiler Laubwälder in der Tschechischen Sozialistischen Republik. Academia, Praha.

Mucina L., Grabherr G., Wallnöfer S. 1993: Die Pflanzengesellschaften Österreichs III. Wälder und Gebüsche. Gustav Fischer, Jena - Stuttgart - New York, 353 pp.

MÜLleR TH., GöRS S. 1958: Zur Kenntnis einiger Auenwaldgesellschaften im württembergischen Oberland. Beiträge zur naturkundlichen Forschung in Südwestdeutschland 17: 88-165.

OBerdorfer E. 1953: Der europäische Auenwald. Beiträge zur Naturkundlichen Forschung in Südwestdeutschland 12: 23-70.

Oberdorfer E. 1992: Süddeutsche Pflanzengesellschaften IV. A. Textband. Gustav Fischer Verlag, Jena - Stuttgart - New York, 282 pp.

PARABUĆs Ki S. 1972: The forest vegetation of the Kovilj marsh (Шумска вегетација Ковиьског рита). Зборник Матице српска за природне науке Нови СаА 42: 5-88.

Paw£ows ki B., SokoŁows ki M., Wallisch K. 1928: Die Pflanzenassoziationen des TatraGebirges VII. Die Pflanzenassoziationen und die Flora des Morskie Oko-Tales. Bulletin International de l'Academie Polonaise des Sciences et des Lettres, Classe des Sciences Mathématiques et Naturelles; Série B: Sciences Naturelles, Cracovie, Suppl. 1927: 205-272.

Plattner G. 1986: Einfluss des Donaukraftwerkes Altenwörth auf die Auwaldvegetation. Diplomarbeit, Universität für Bodenkultur Wien.

PODANI J. 2001: SYN-TAX 2000 Computer programs for data analysis in ecology and systematics. Scientia, Budapest, $53 \mathrm{pp}$.

SAUBERER A. 1942: Die Vegetationsverhältnisse der Unteren Lobau. Niederdonau/Natur und Kultur 17, Wien 17: 55.

Simon T. 1957: Die Wälder des nördlichen Alföld. In: Zólyomi B. (red.): Die Vegetation ungarischer Landschaften 1. Akadémiai Kiadó, Budapest, 172 pp. +22 tab. +2 chart.

Simon T., Szabó M., Draskovits R., Hahn I. et Gergely A. 1993: Ecological and phytosociological changes in the willow woods of Szigetköz, NW Hungary, in the past 60 years. Abstracta Botanica 17(1-2): 179-186.

SLAVNić Ž. 1952: Die Niederungswälder der Vojvodina (САавнић, Ж. Низинске шуме Војводине). Зборник Матице српске за природне науке Нови СаА 2: 1-22.

Soó R. 1930: A modern növényföldrajz problémái, irányai és irodalma. A növényszociológia Magyarországon. Magyar Biológiai Kutatóintézet Munkái 3: 1-51.

Soó R. 1958: Die Wälder des Alföld. Acta Botanica Academiae Scientiarum Hungaricae 4: 351-381.

Soó R. 1964, 1966, 1968, 1970, 1973, 1980: A magyar flóra és vegetáció rendszertani-növényföldrajzi kézikönyve I-VI. Akadémiai kiadó, Budapest.

Stoскнамmer, G. 1964: Die pflanzensoziologische Kartierung des Gemeindegebietes Linz/ Donau. In: Kulturverwaltung der Stadt Linz (Hrsg.), Linzer Atlas. Druck- und Verlagsanstalt Gutenberg, Linz.

STRAKA, A. 1992: Ufervegetation am Giessgang in den Donauauen zwischen Altenwörth und Korneuburg. Diplomarbeit, Universität Wien.

Szirmai O., Tuba Z., Nagy J., Cserhalmi D., Czóbel Sz., Gál B., Szerdahelyi T., MarSCHALL Z. 2008: A Bodrogköz növénytársulásainak áttekintése. In: TUBA Z. (szerk.) Bod- 
rogköz. A magyarországi Bodrogköz tájmonográfiája. Lorántffy Zsuzsanna Szellemében Alapítvány, Gödöllő-Sárospatak, pp. 523-584.

Tсноu Y. T. 1949a: Études écologiques et phytosociologiques sur les Forêts Riveraines du BasLanguedoc (Populetum albae) I. Vegetatio Acta Botanica 1(1) 1948: 2-31.

Тсноч Y. T. 1949b: Études écologiques et phytosociologiques sur les Forêts Riveraines du BasLanguedoc (Populetum albae) II. Vegetatio Acta Botanica 1(2-3) 1948: 93-128.

Tсноu Y. T. 1949c: Études écologiques et phytosociologiques sur les Forêts Riveraines du BasLanguedoc (Populetum albae) III. Vegetatio Acta Botanica 1(4-5) 1948: 217-257.

Тсноu Y. T. 1949d: Études écologiques et phytosociologiques sur les Forêts Riveraines du BasLanguedoc (Populetum albae) IV. Vegetatio Acta Botanica 1(6) 1948: 347-384.

Tóтн I. 1958: Az Alsó-Dunaártér erdőgazdálkodása, a termőhely- és az erdőtípusok összefüggése. Erdészeti Kutatások 1958(1-2): 77-160.

VLIEger J. 1937: Aperçu sur les unités phytosociologiques supérieures des Pays-Bas. Nederlandsh Kruidkundig Archief 47: 335.

Wendelberger-Zelinka E. 1952: Die Vegetation der Donauauen bei Wallsee. Oberöstereichischer Landesverlag, Wels, 196 pp.

Wendelberger G. 1955: Die Restwälder der Parndorfer Platte im Nordburgenland. - Burgenländische Forschungsgesellschaft, Eisenstadt 29: 1-175.

\title{
The syntaxonomical relationship of softwood and hardwood gallery forests in the Szigetköz, NW Hungary
}

\author{
B. KEVEY \\ University of Pécs, Department of Ecology, Ifjúság útja 6, H-7624 Pécs; \\ keveyb@gamma.ttk.pte.hu
}

Accepted: 25 February 2016

Key words: Hungarian Plain, landscape protection area, syntaxonomy, white poplar.

The syntaxonomical relationship of riparian forest communities in the Danube Basin has been subject to repeated debate. To provide further support to the most recently proposed classification, I analyzed 100 vegetation samples collected from softwood and hardwood gallery forests (Leucojo aestivi-Salicetum albae, Senecioni sarracenici-Populetum albae, Pimpinello majoris-Ulmetum populosum albae, Pimpinello majoris-Ulmetum typicum) in the Szigetköz, NW Hungary. The proportion of character species, as well as groupings of samples by multivariate methods (cluster and principal coordinates analyses) unequivocally indicate distinctness of the three studied associations, and render support to the proposition that white poplar may be a dominant species in different associations (e.g. Senecioni sarracenici-Populetum albae and Pimpinello majoris-Ulmetum populosum albae). 


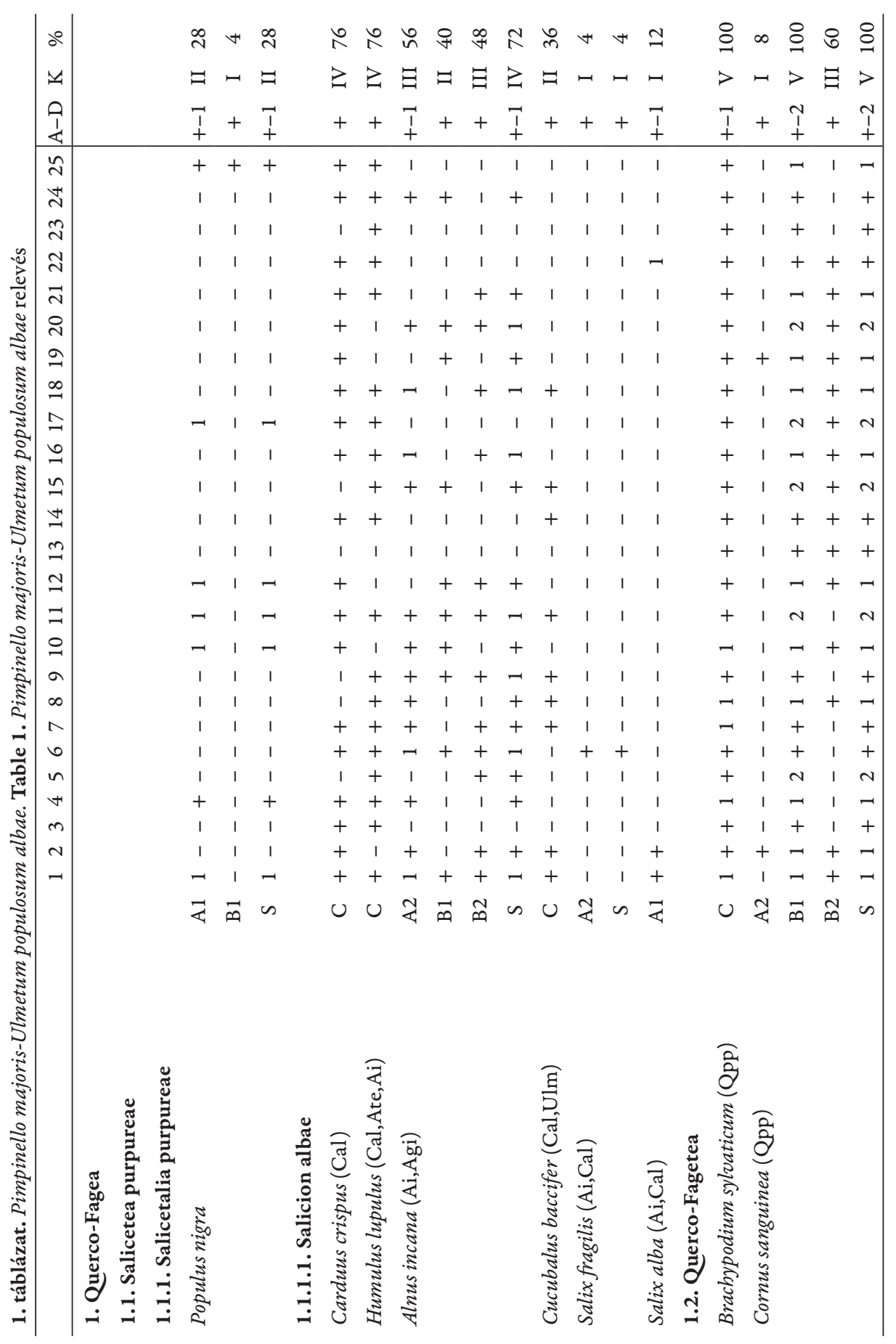




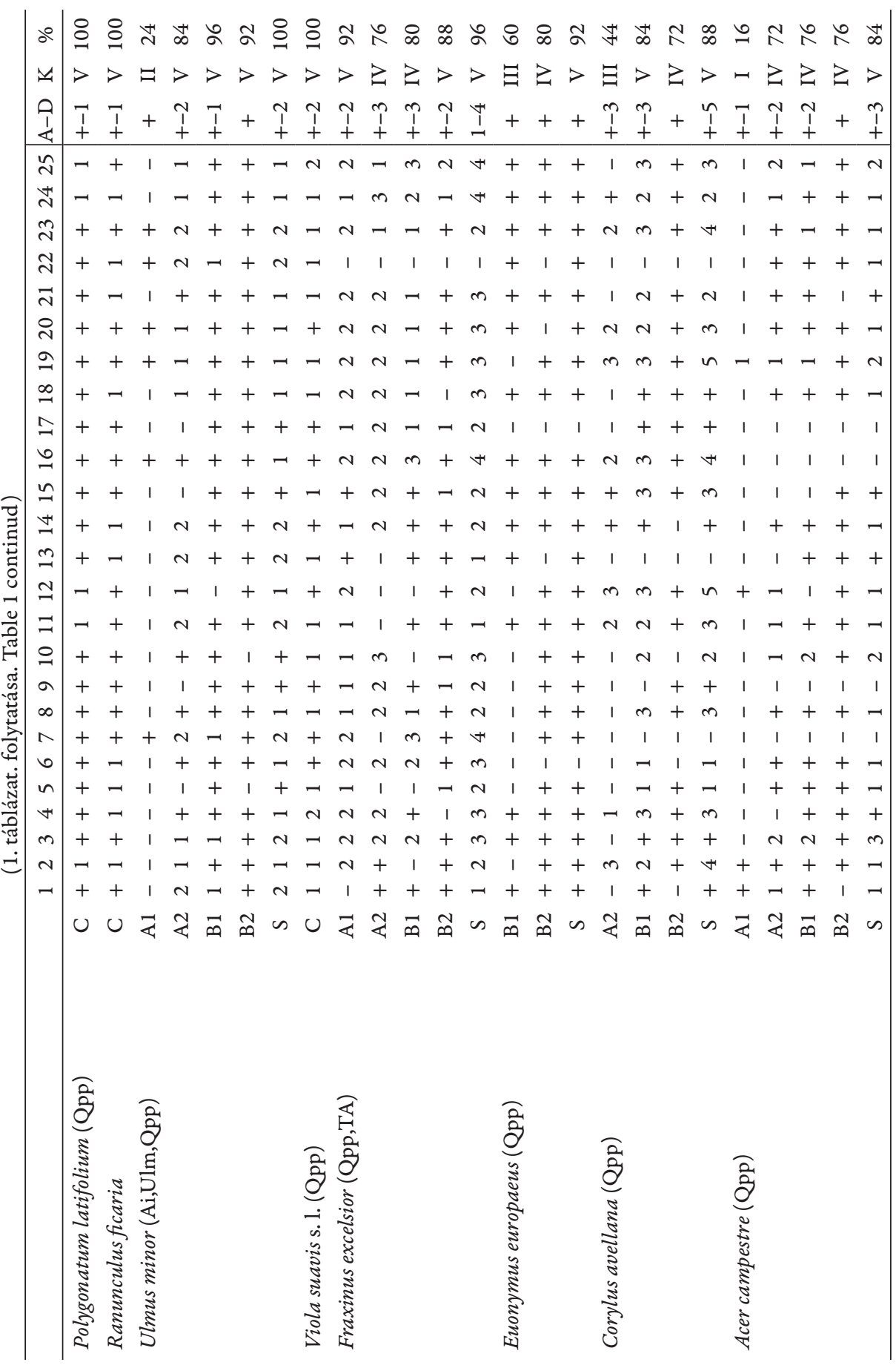




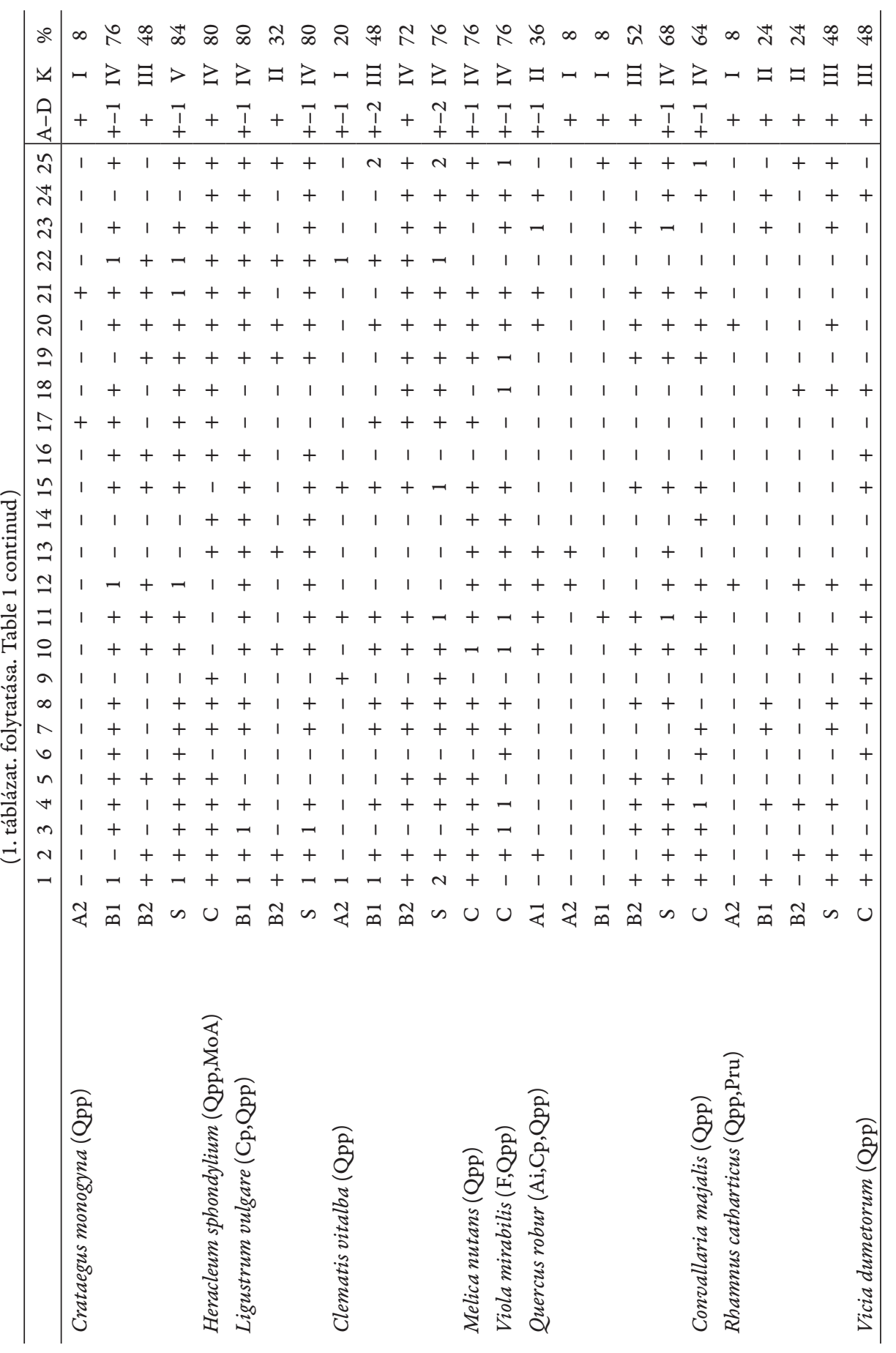




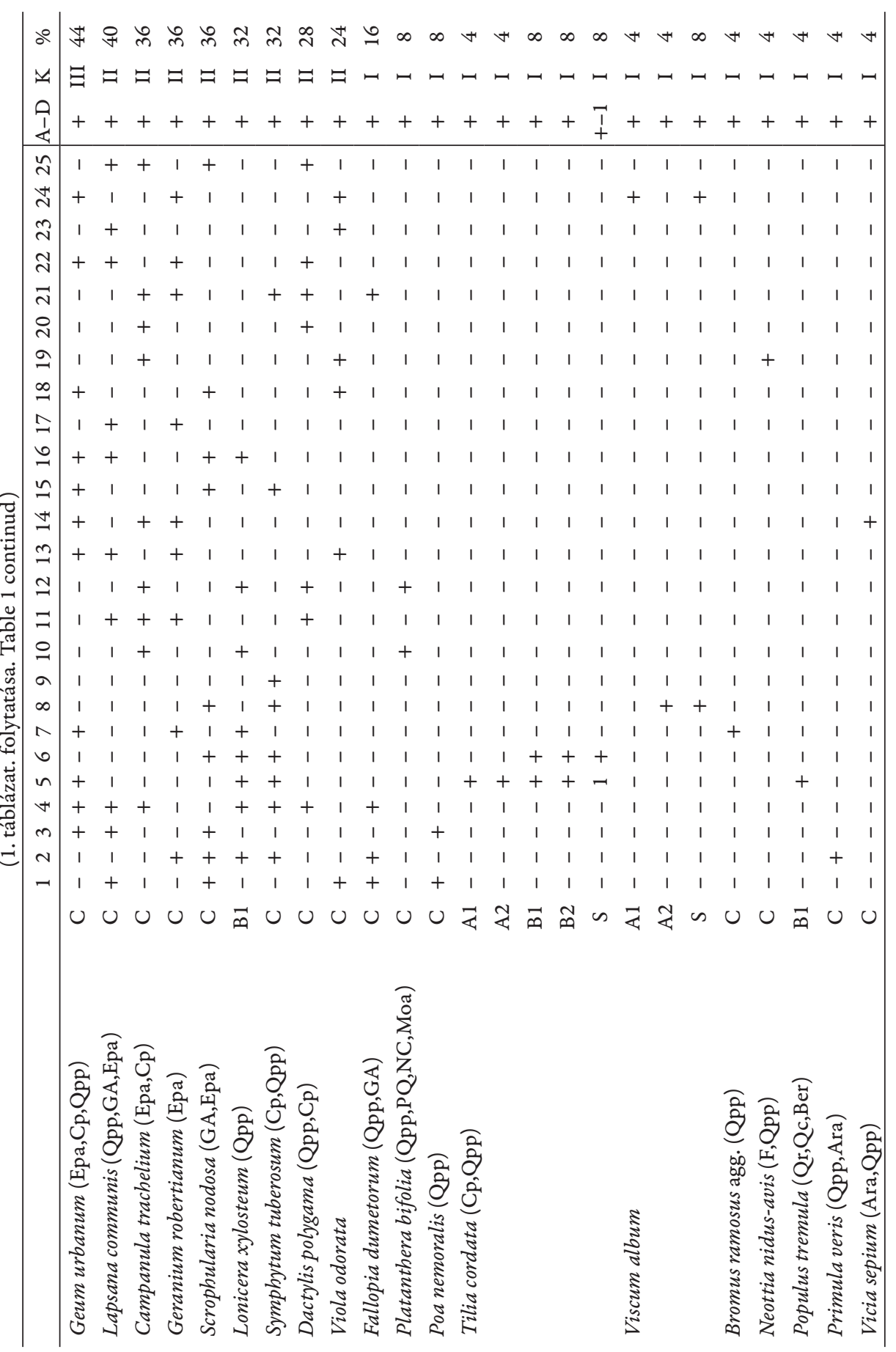




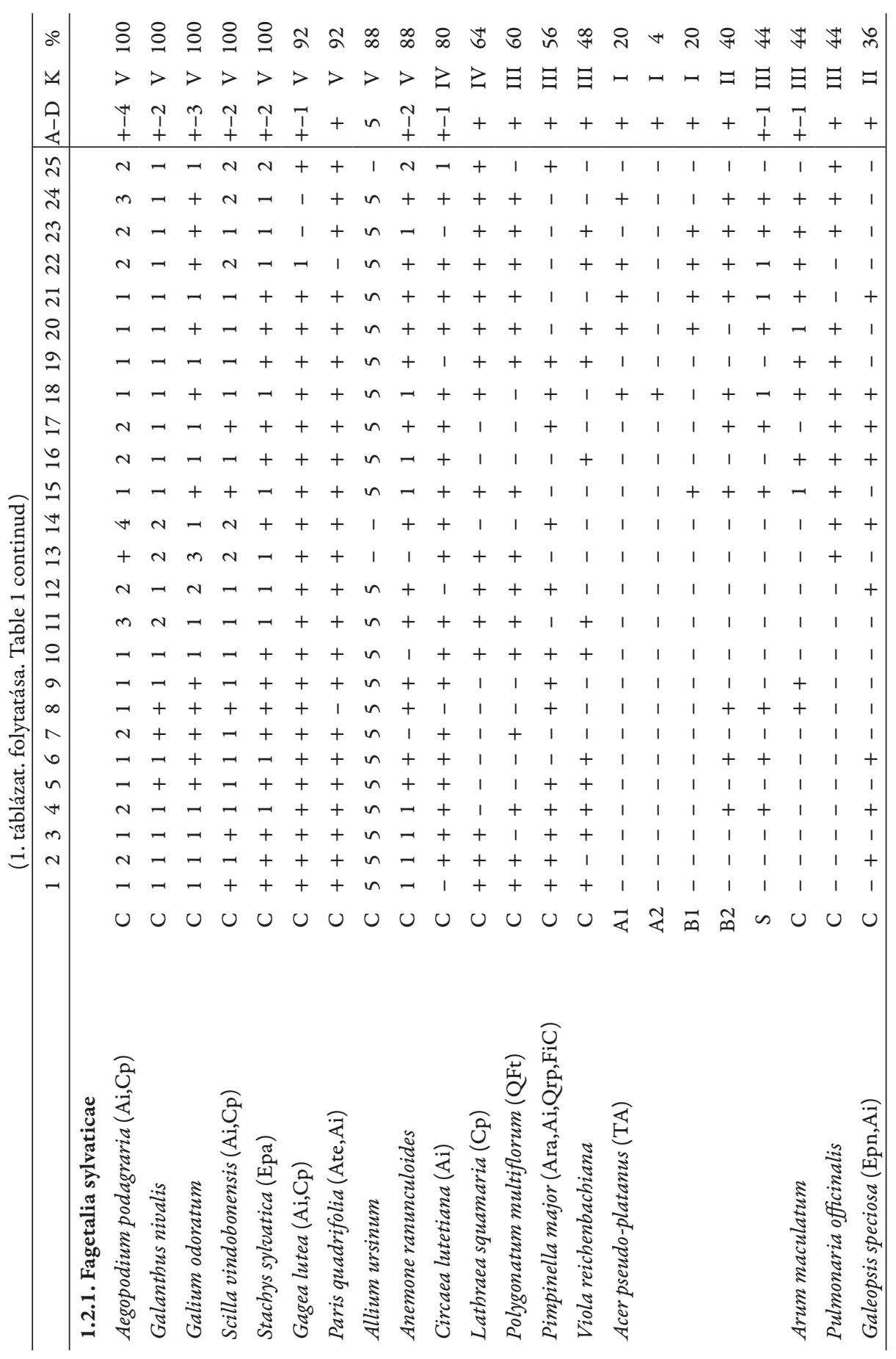




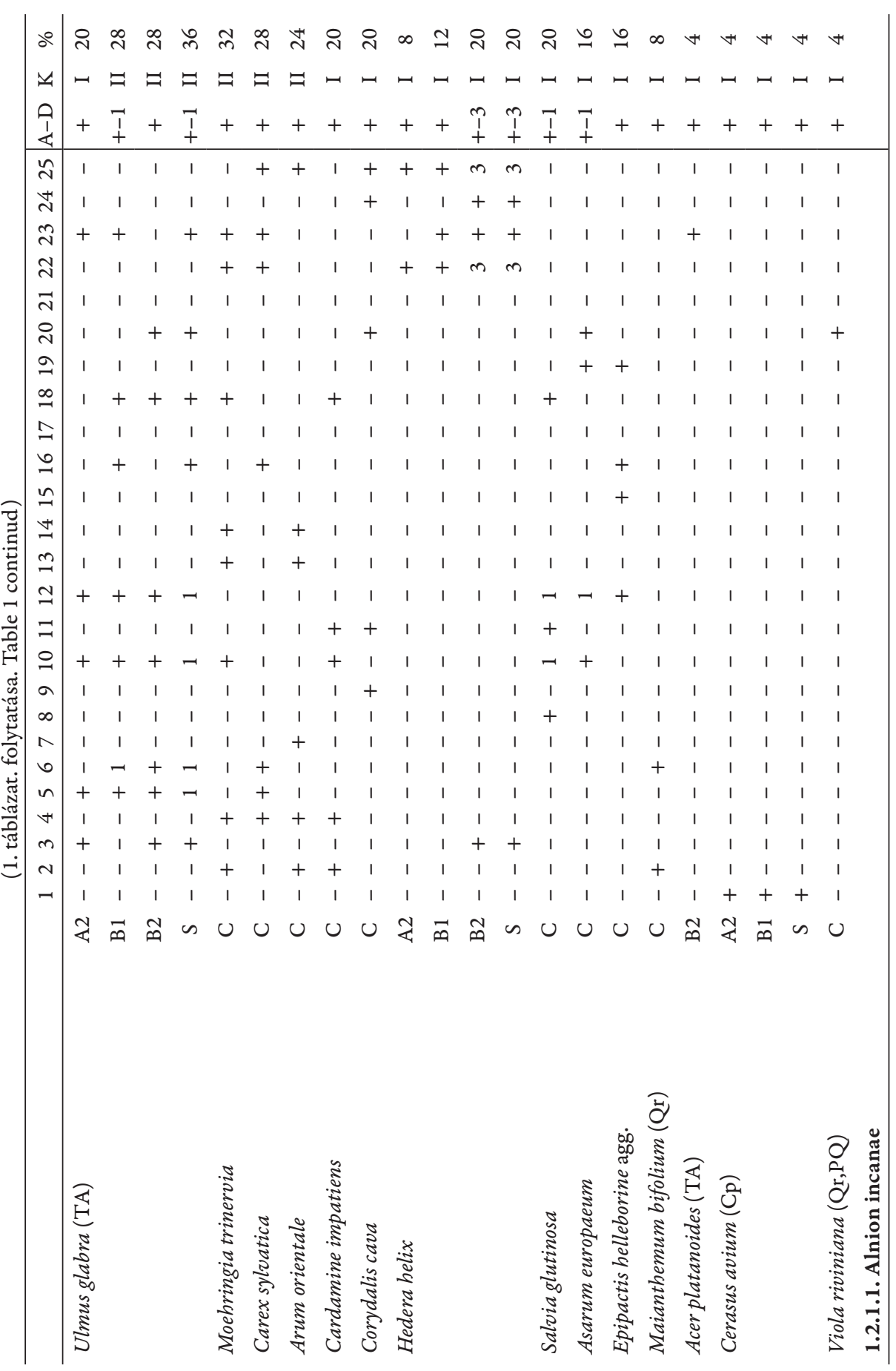




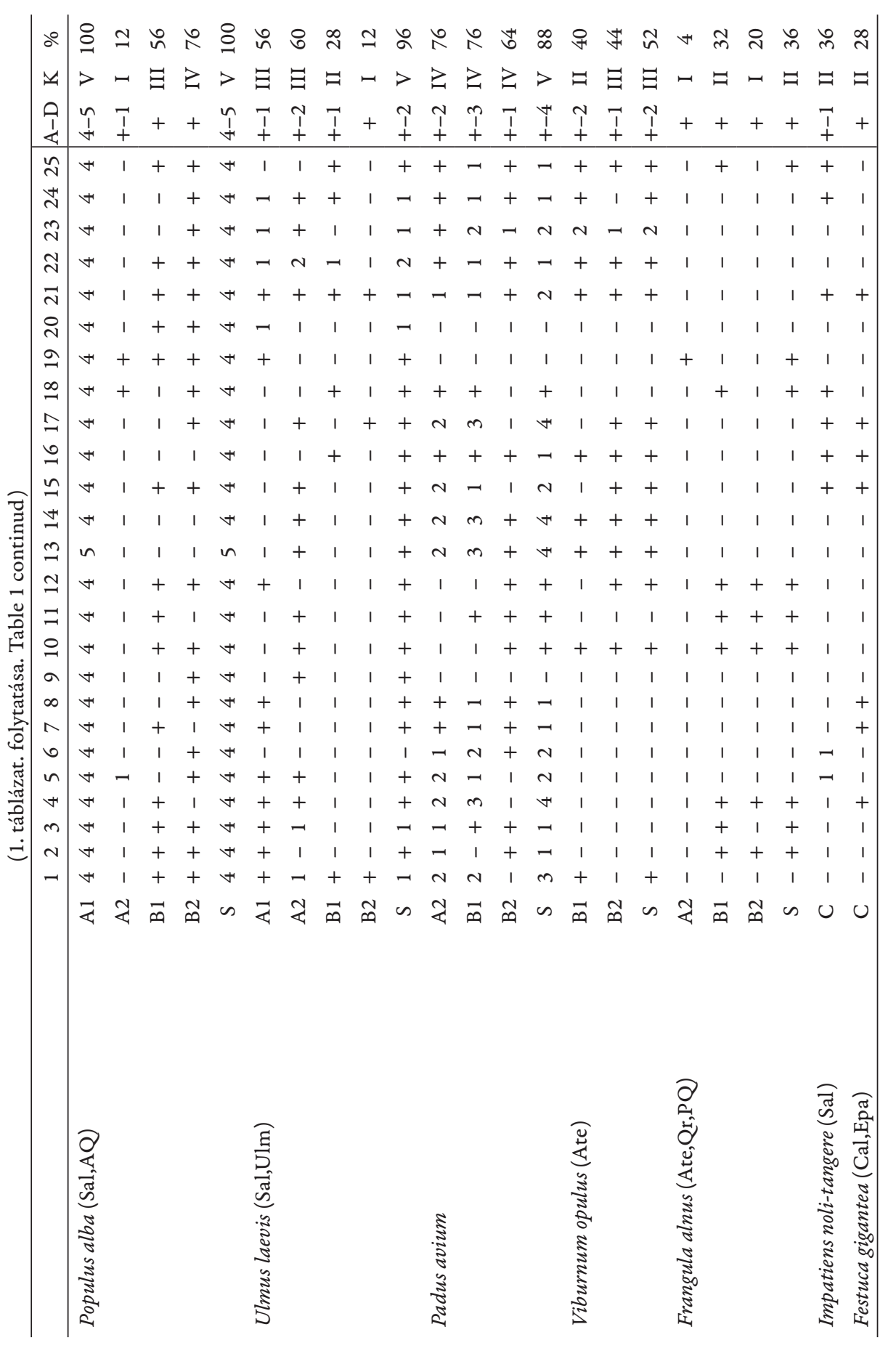




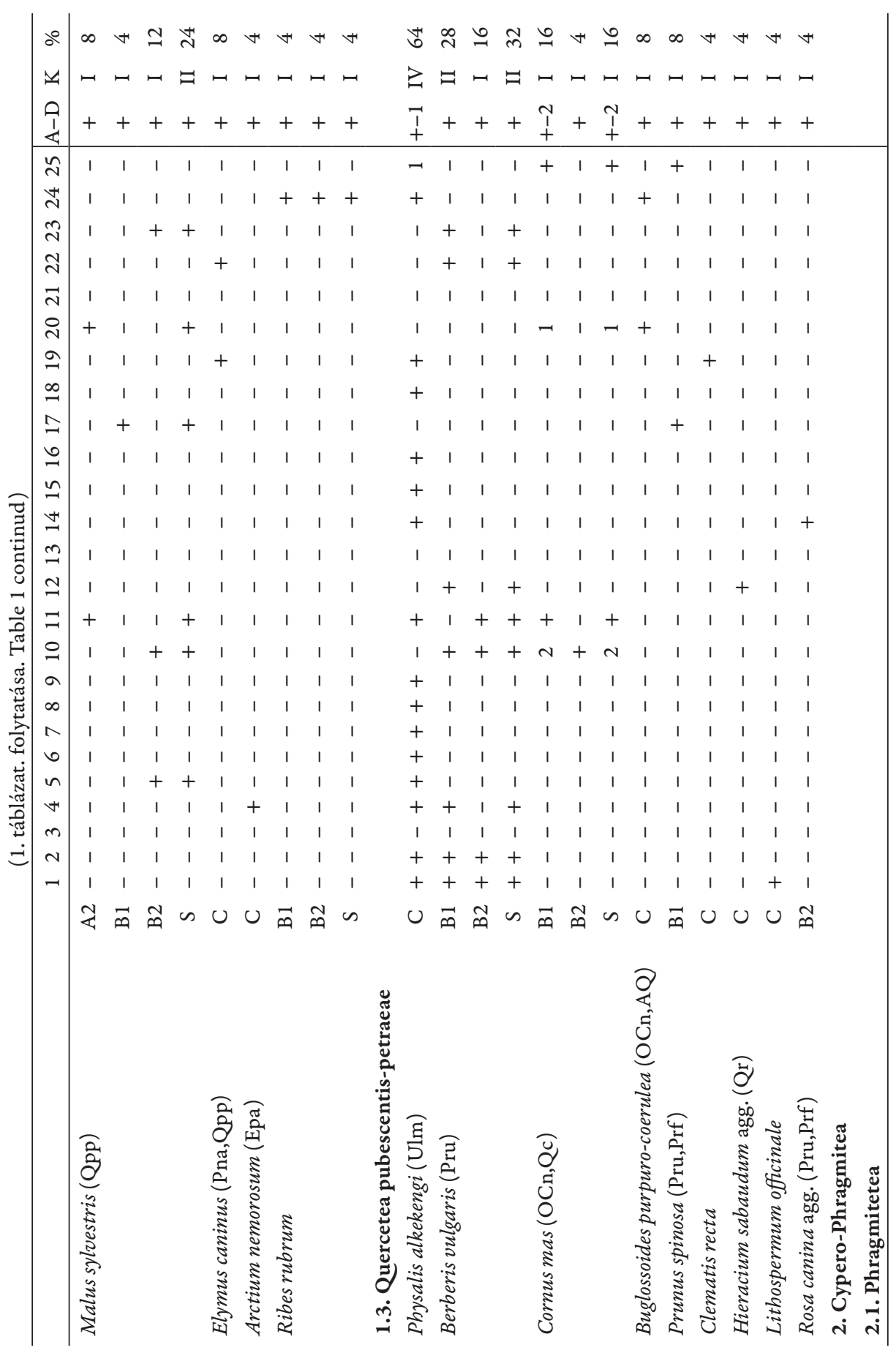


Kevey B.

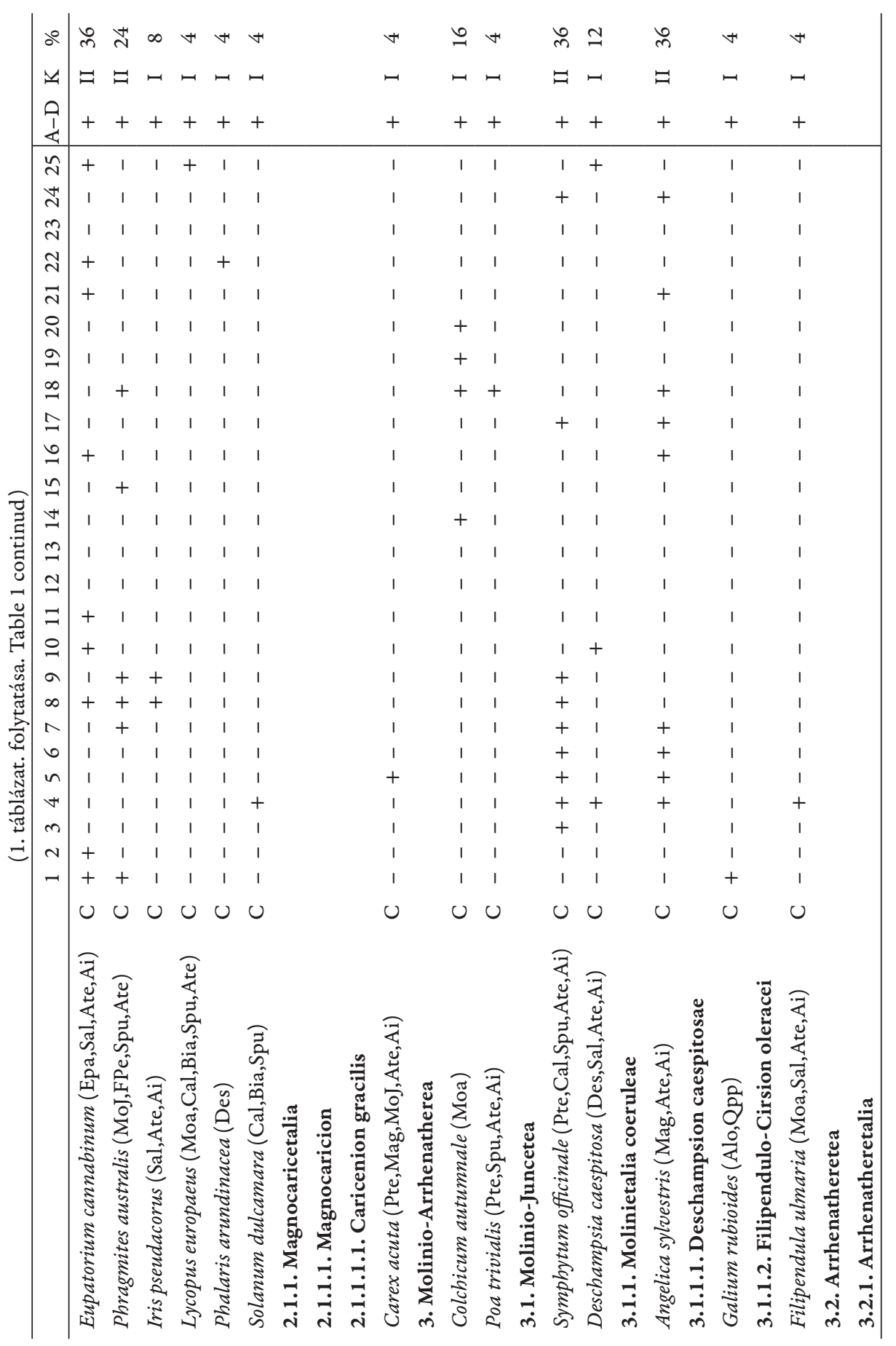




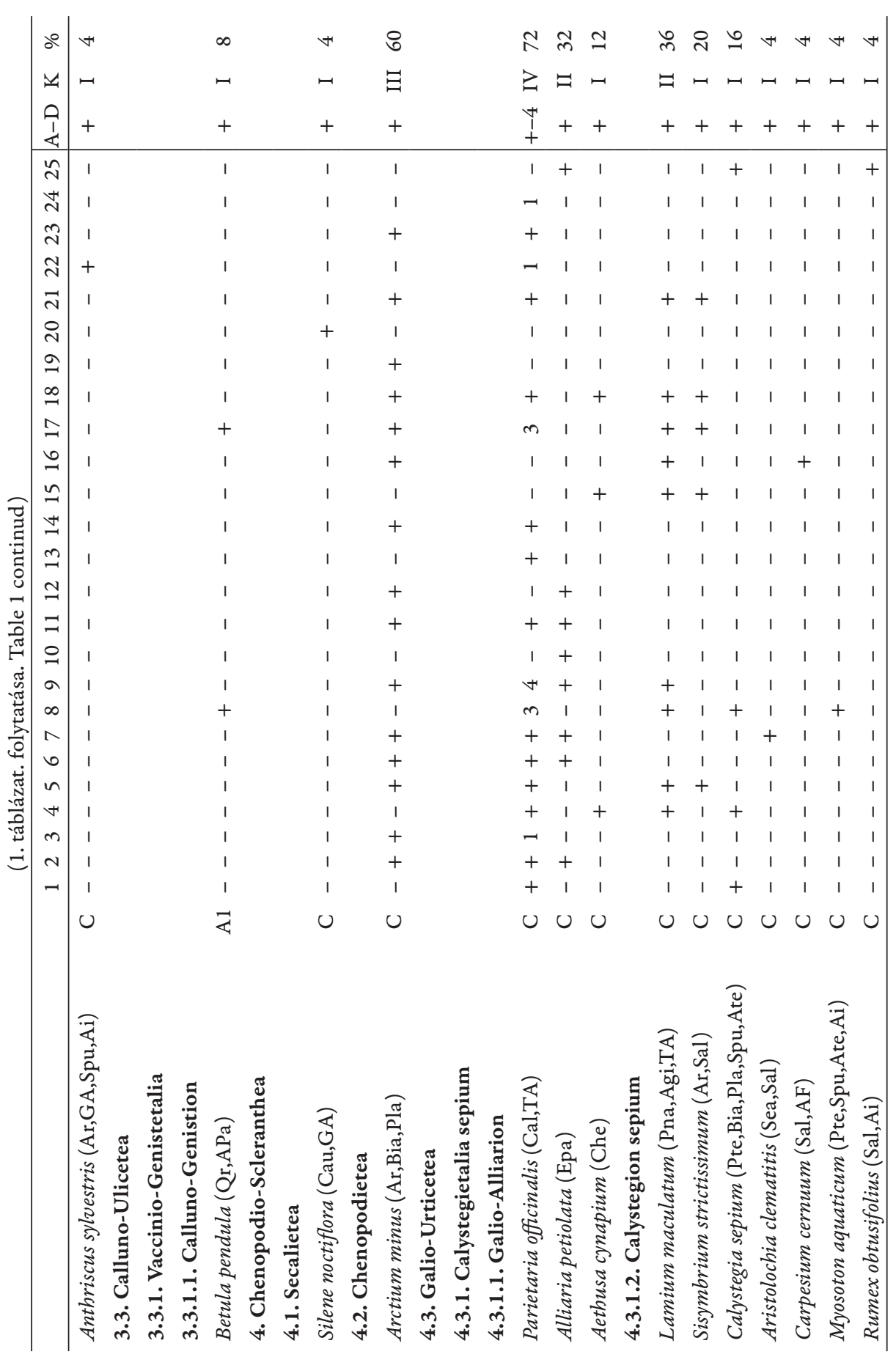




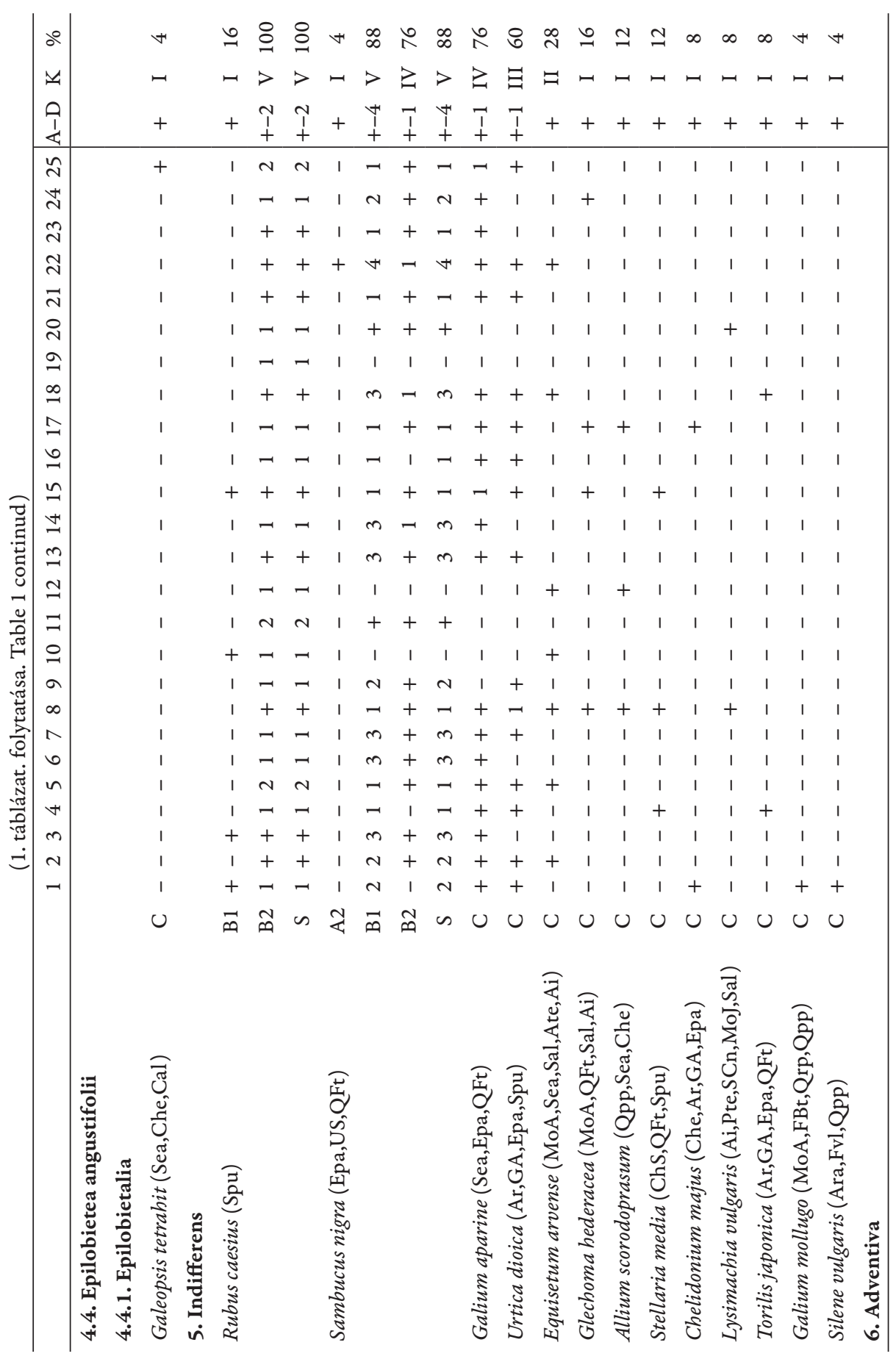




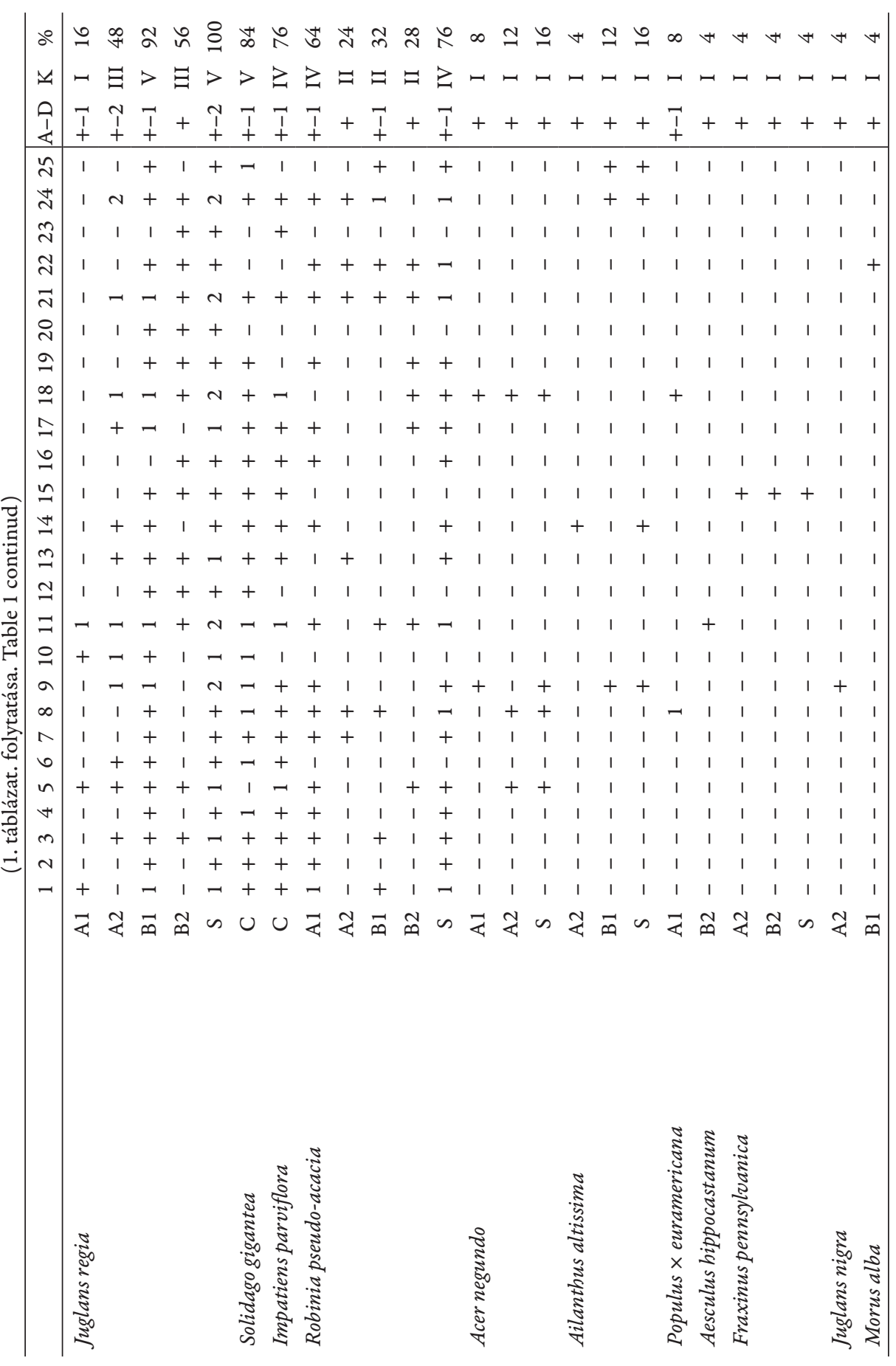




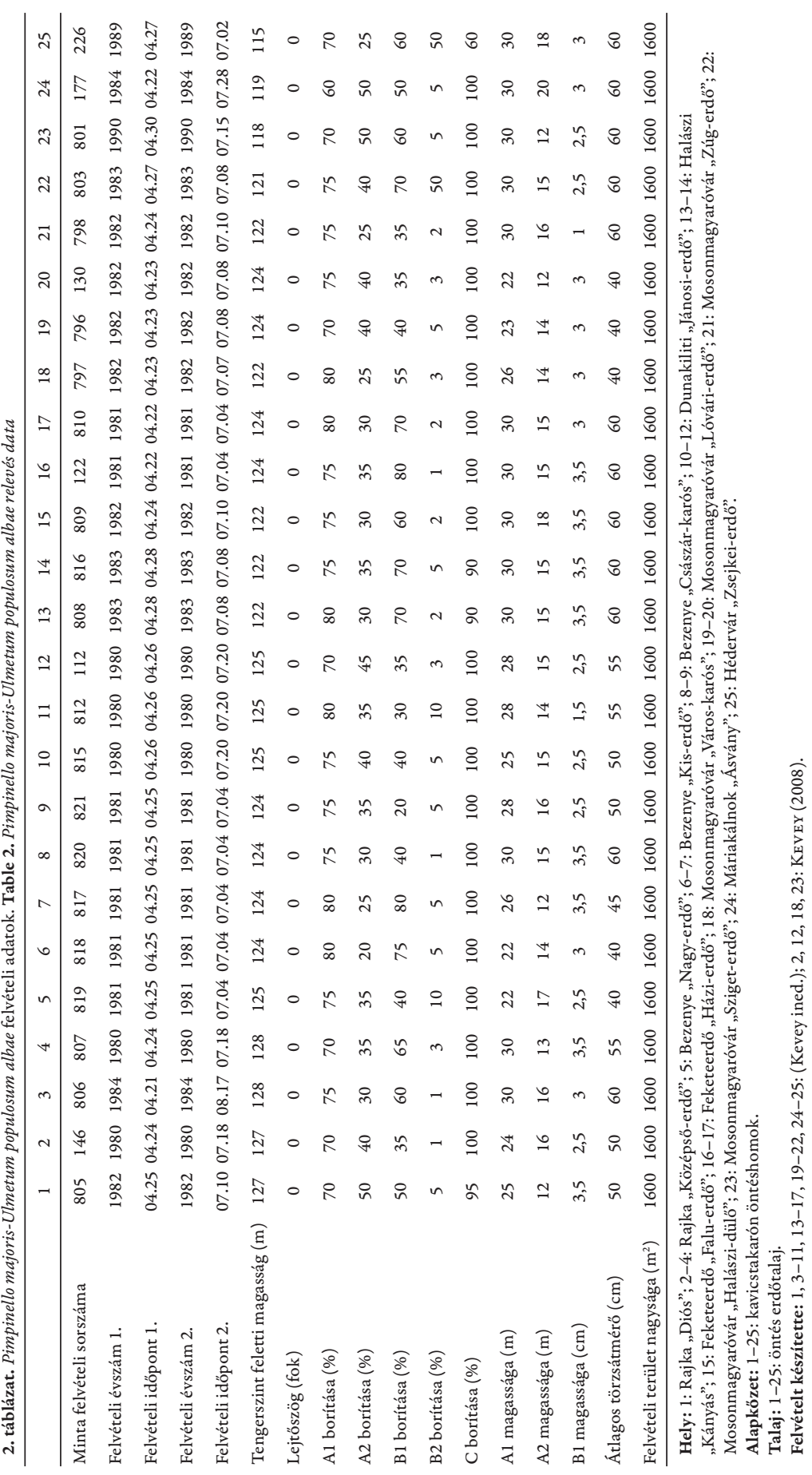




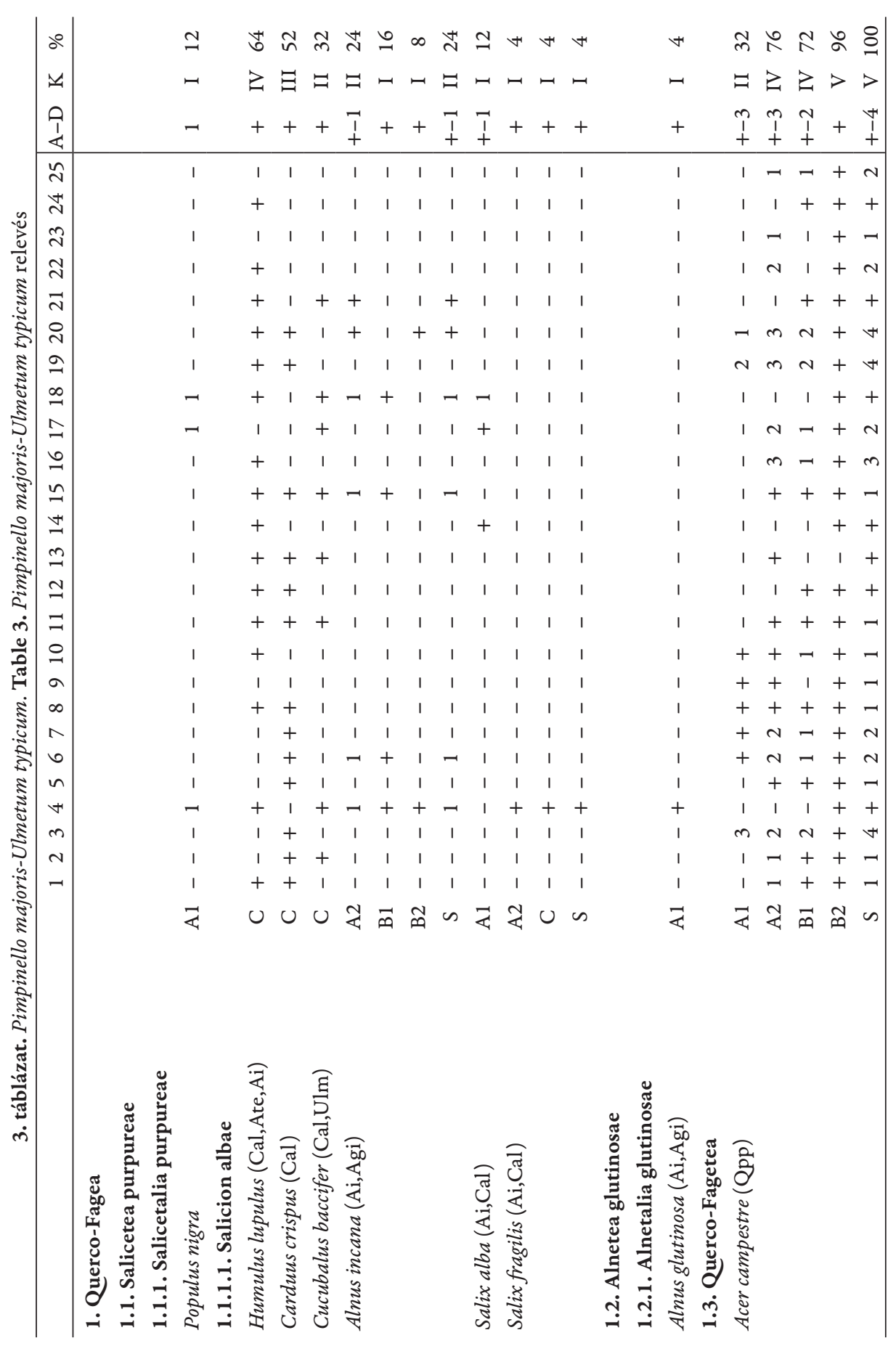




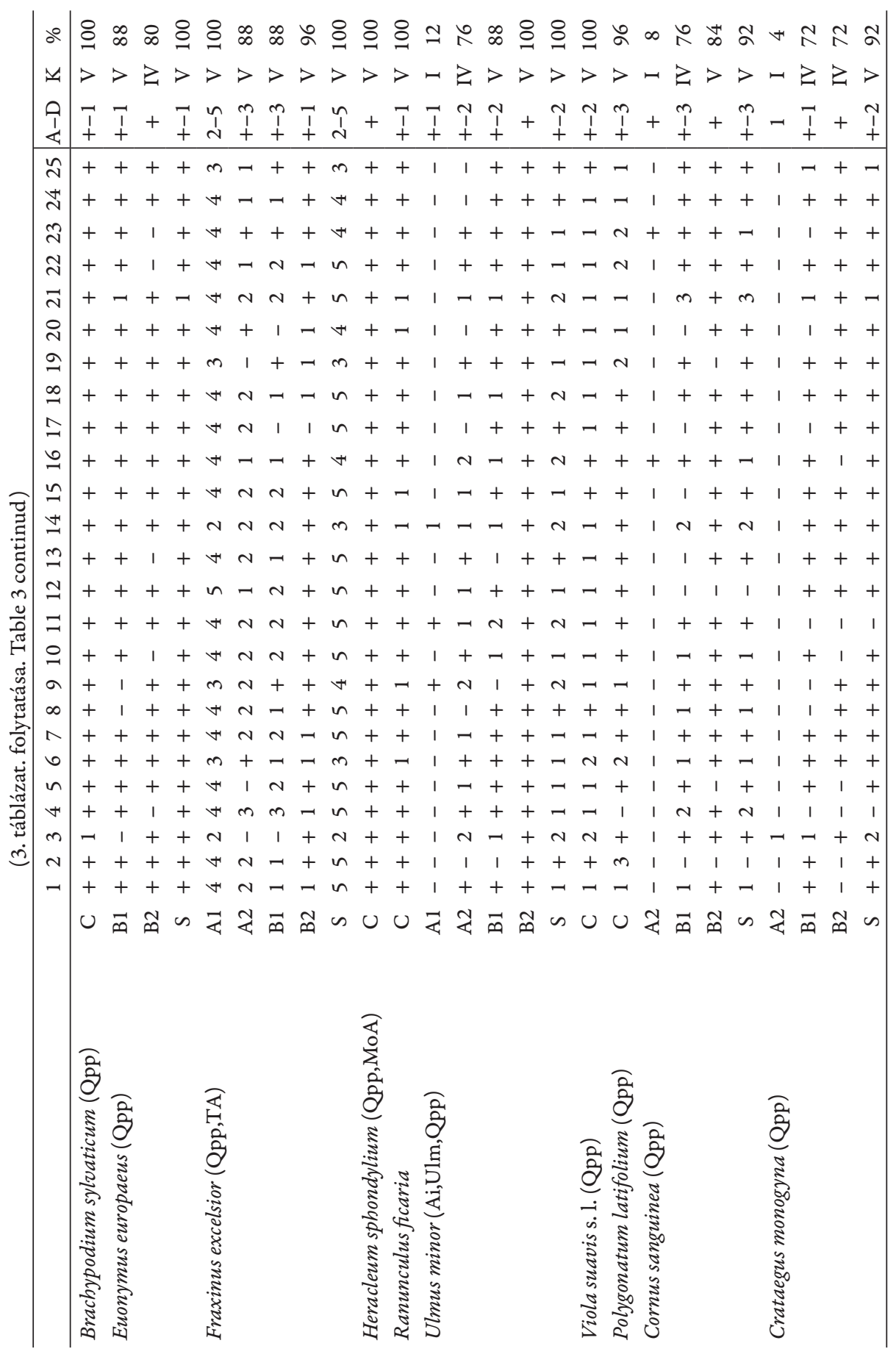




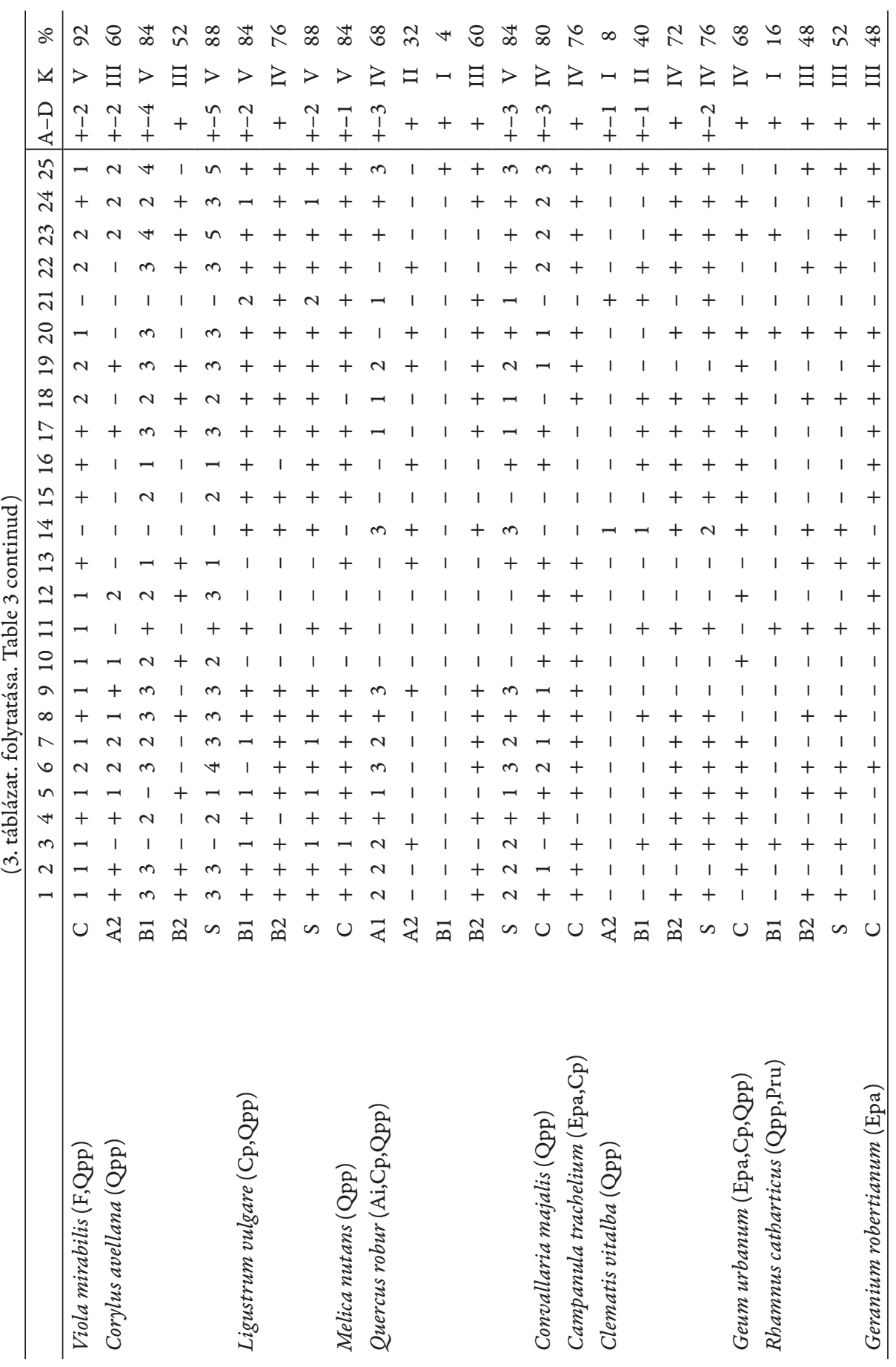


Kevey B.

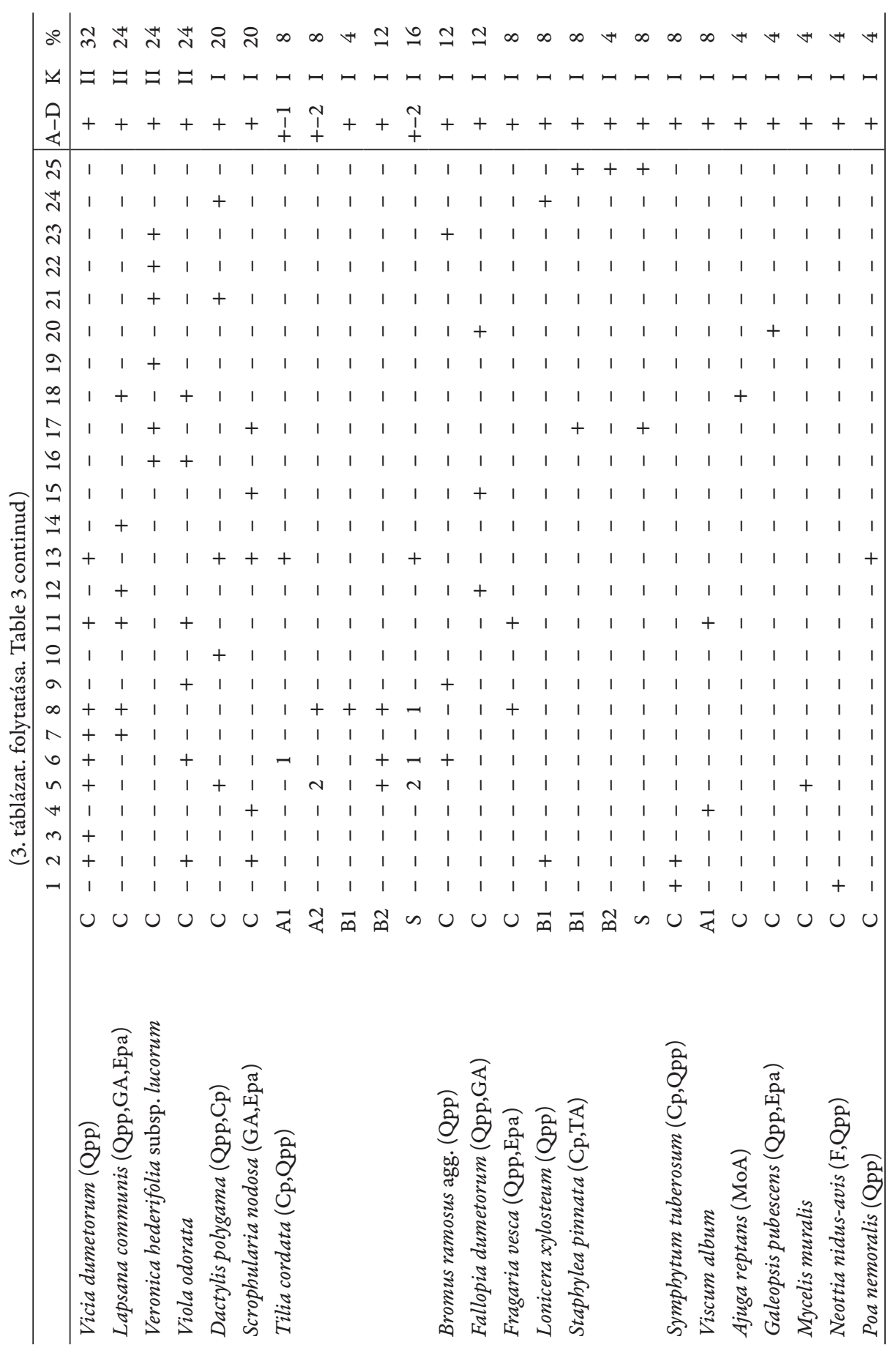




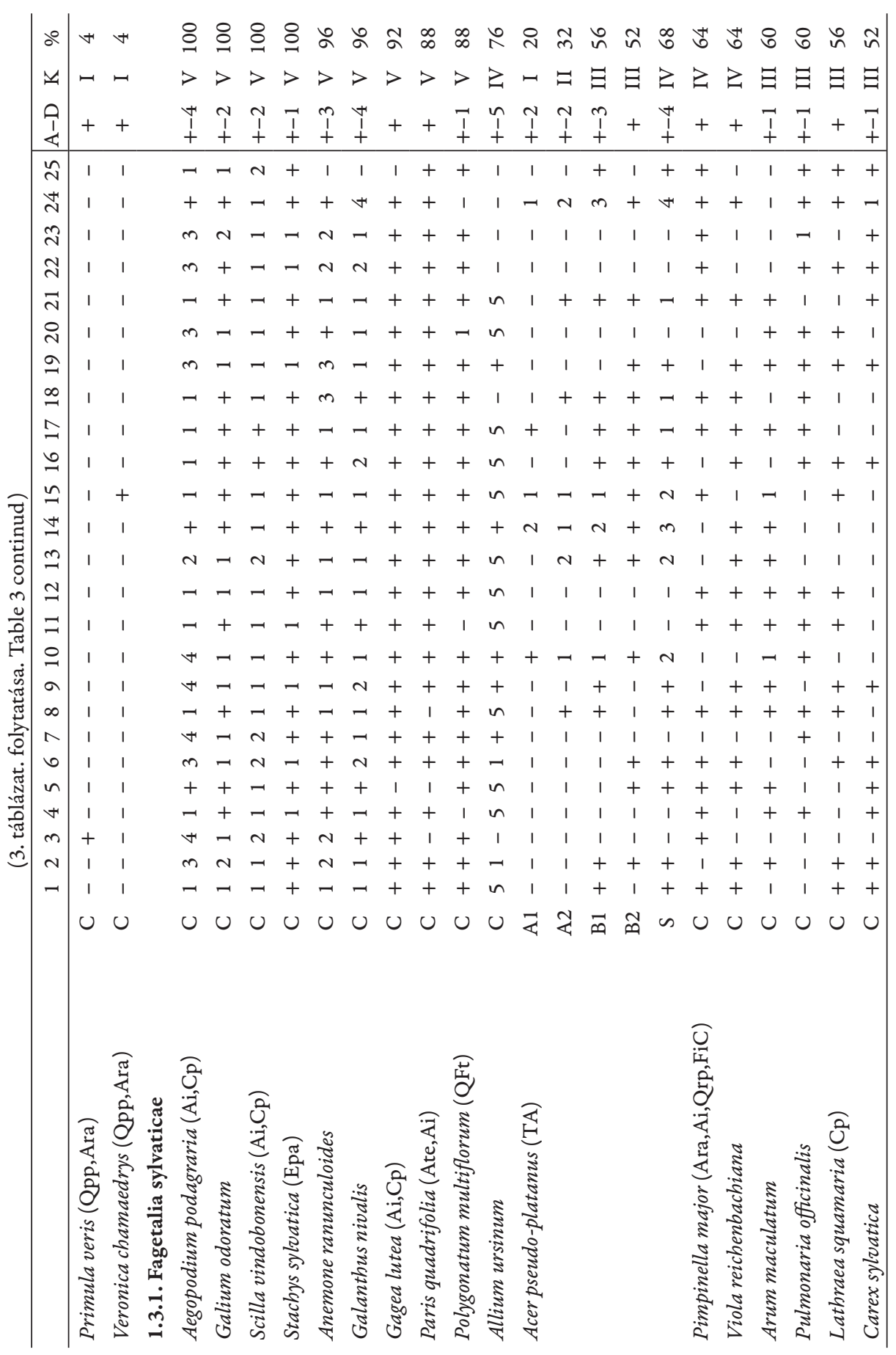




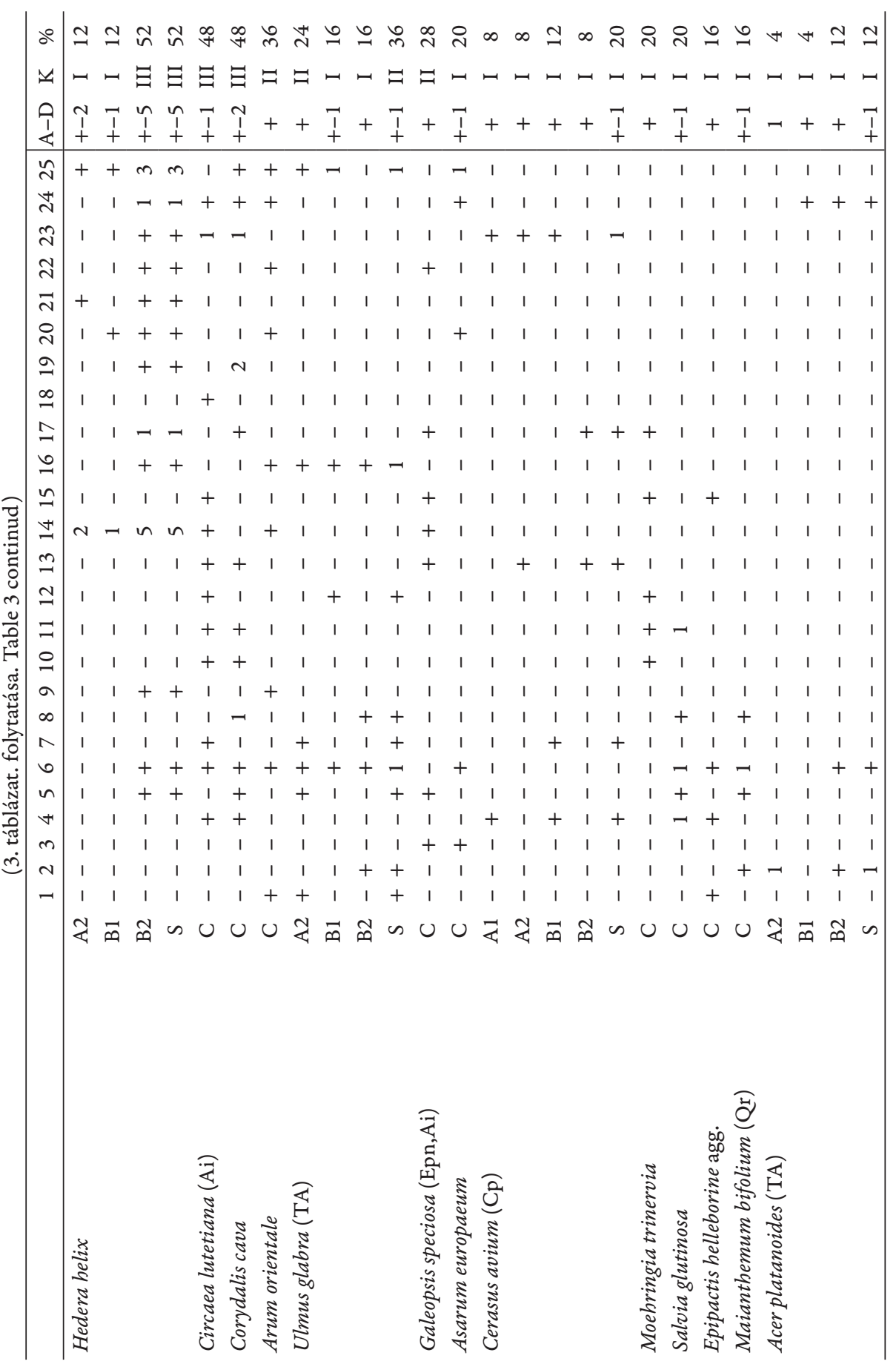




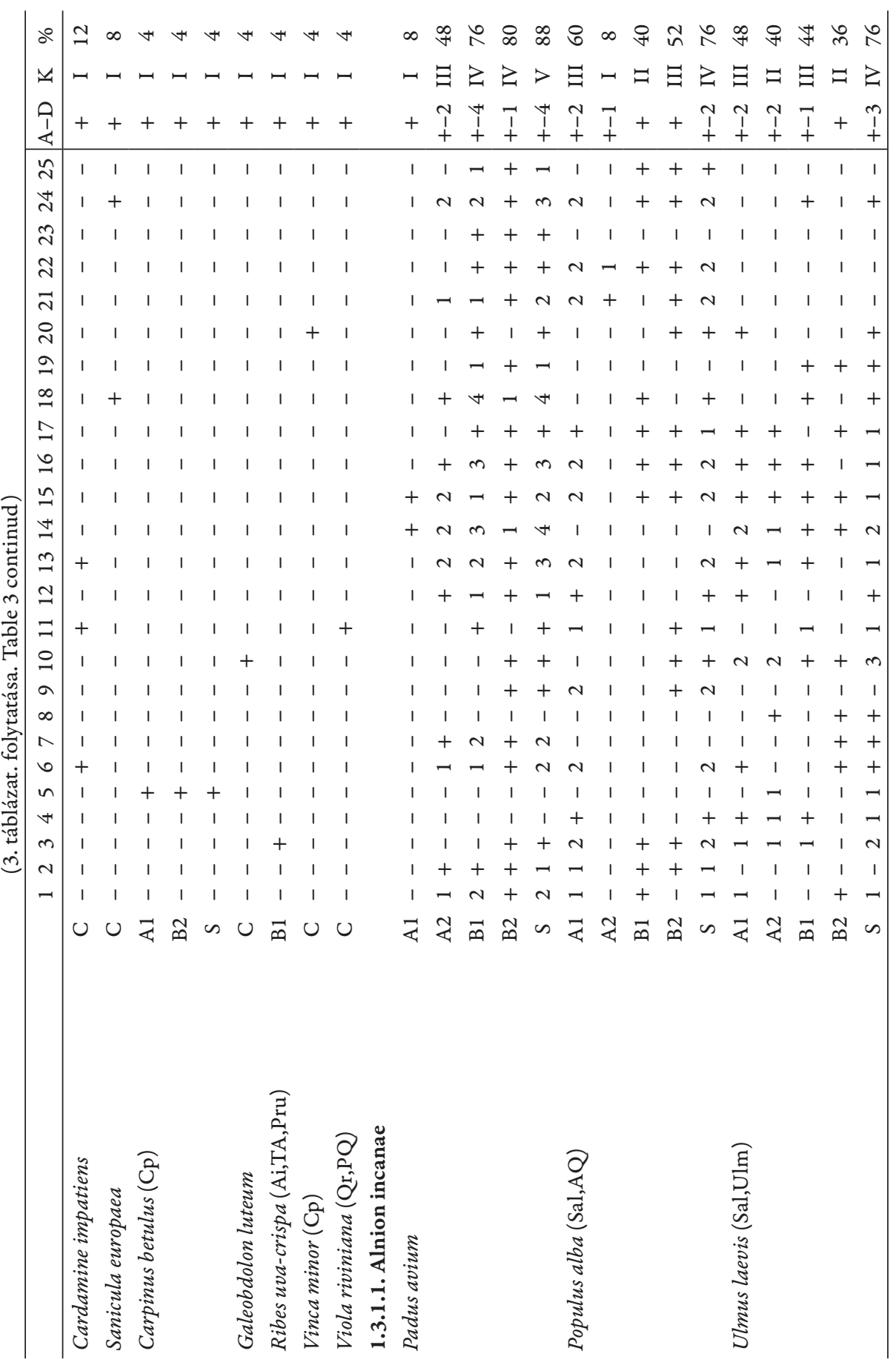




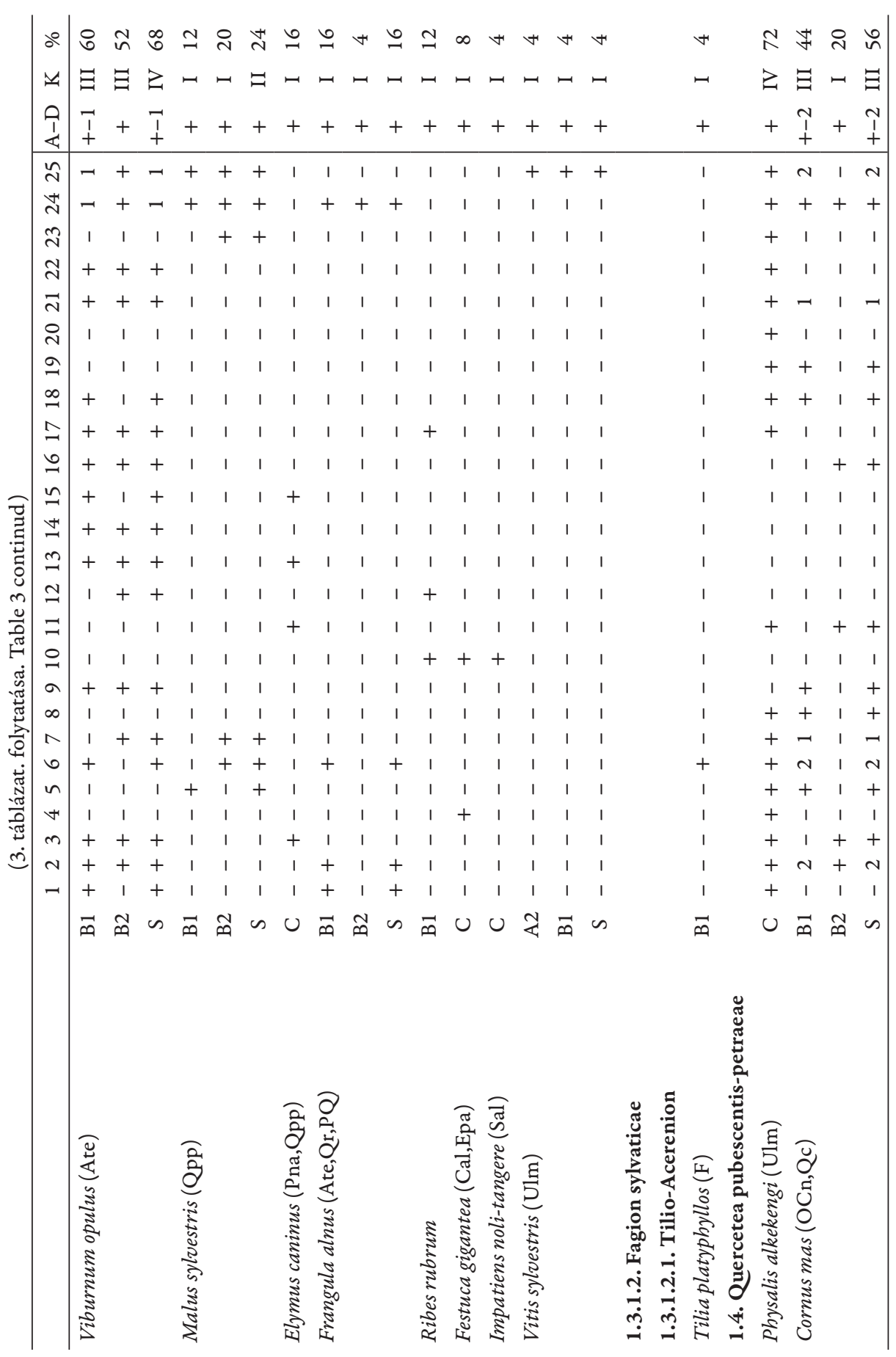




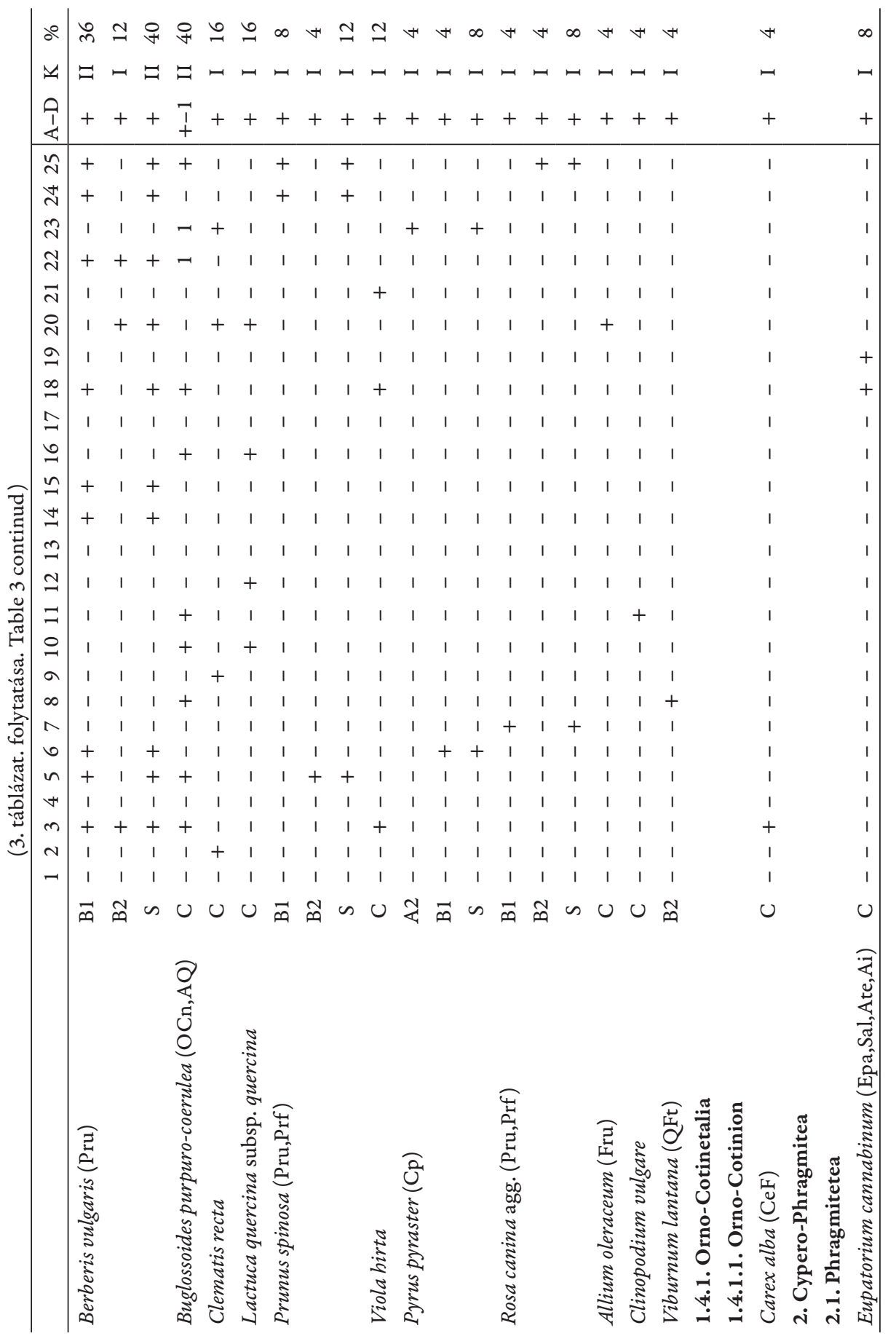




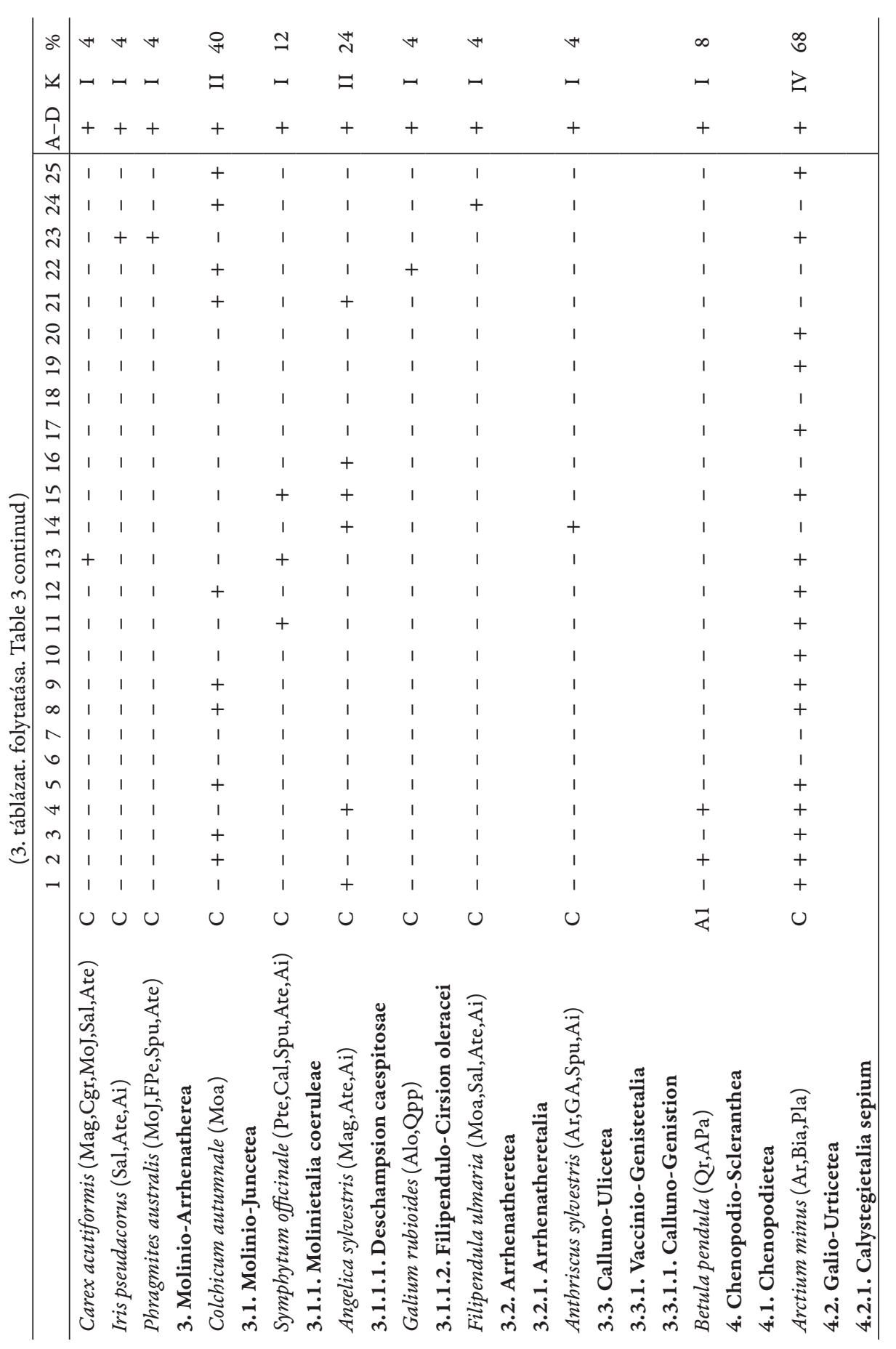




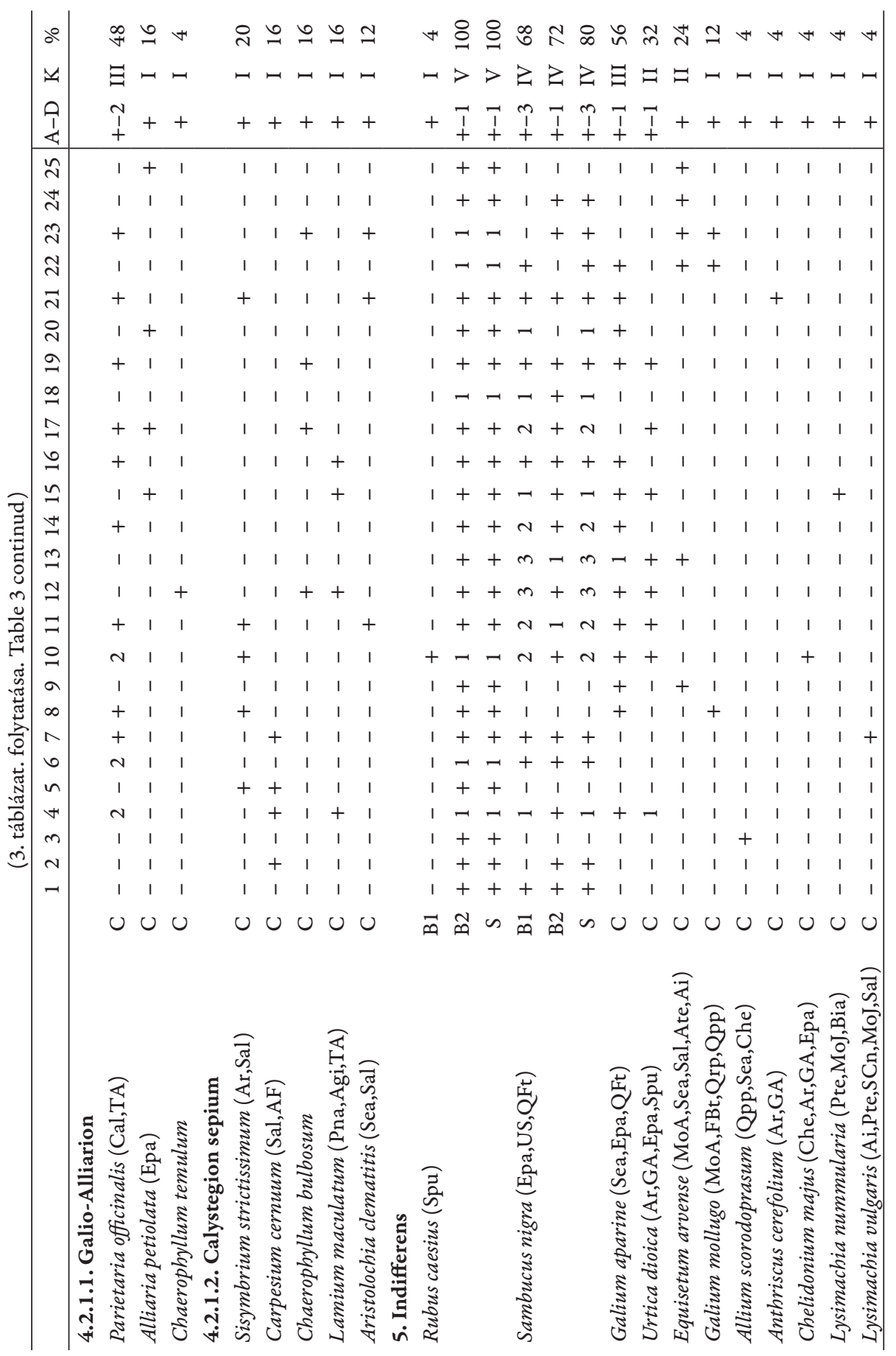




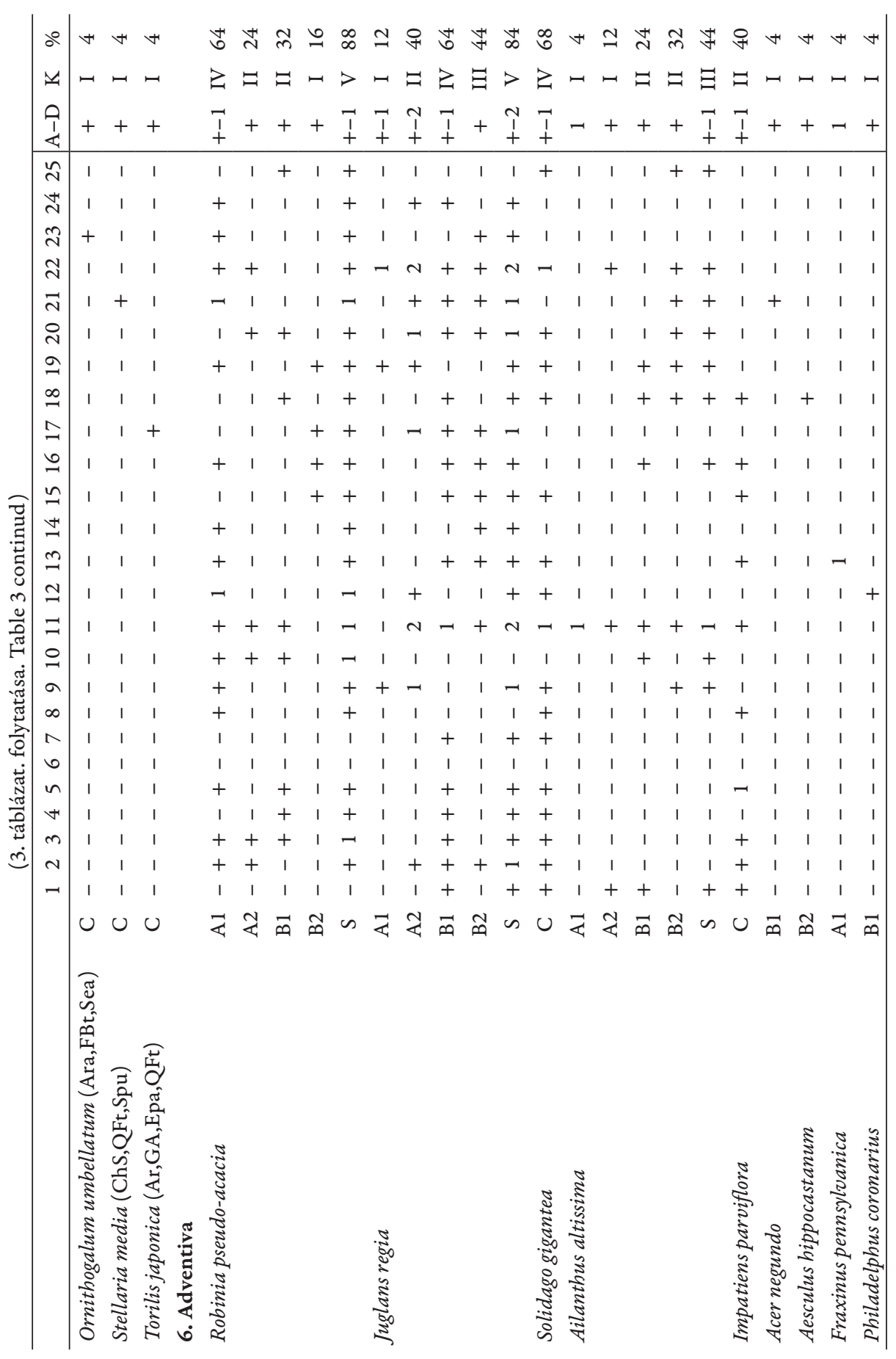




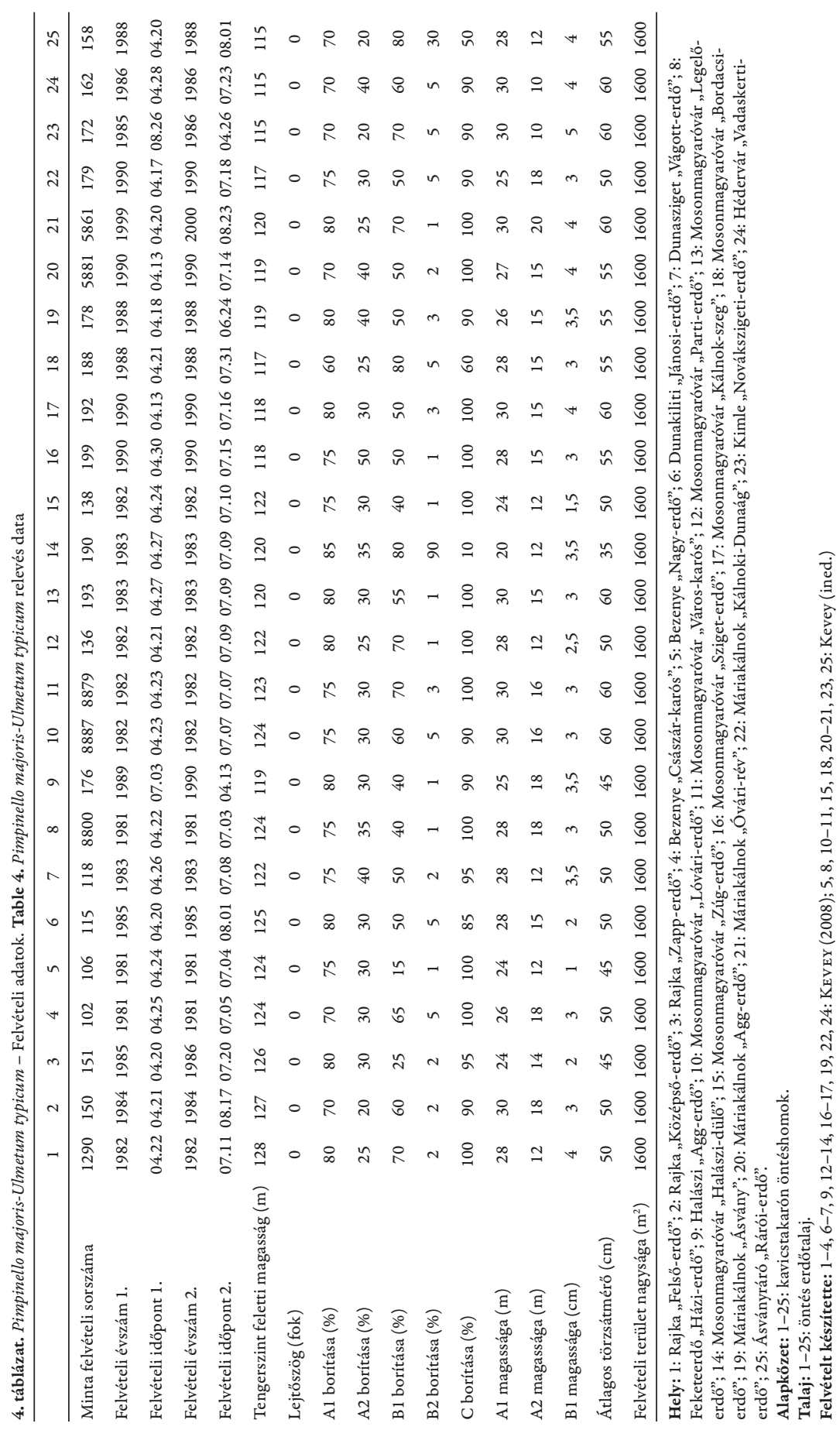


Kevey B.

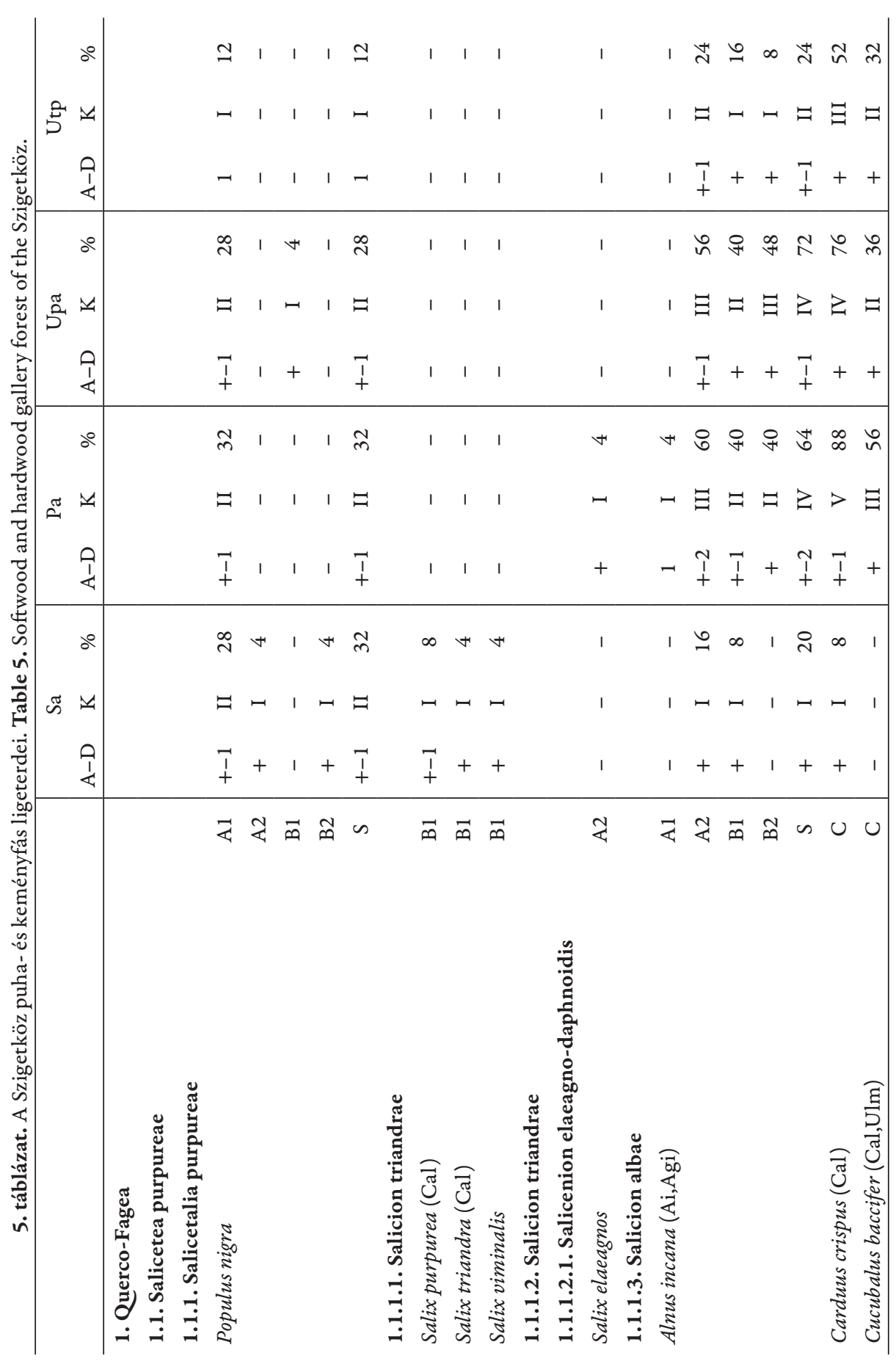




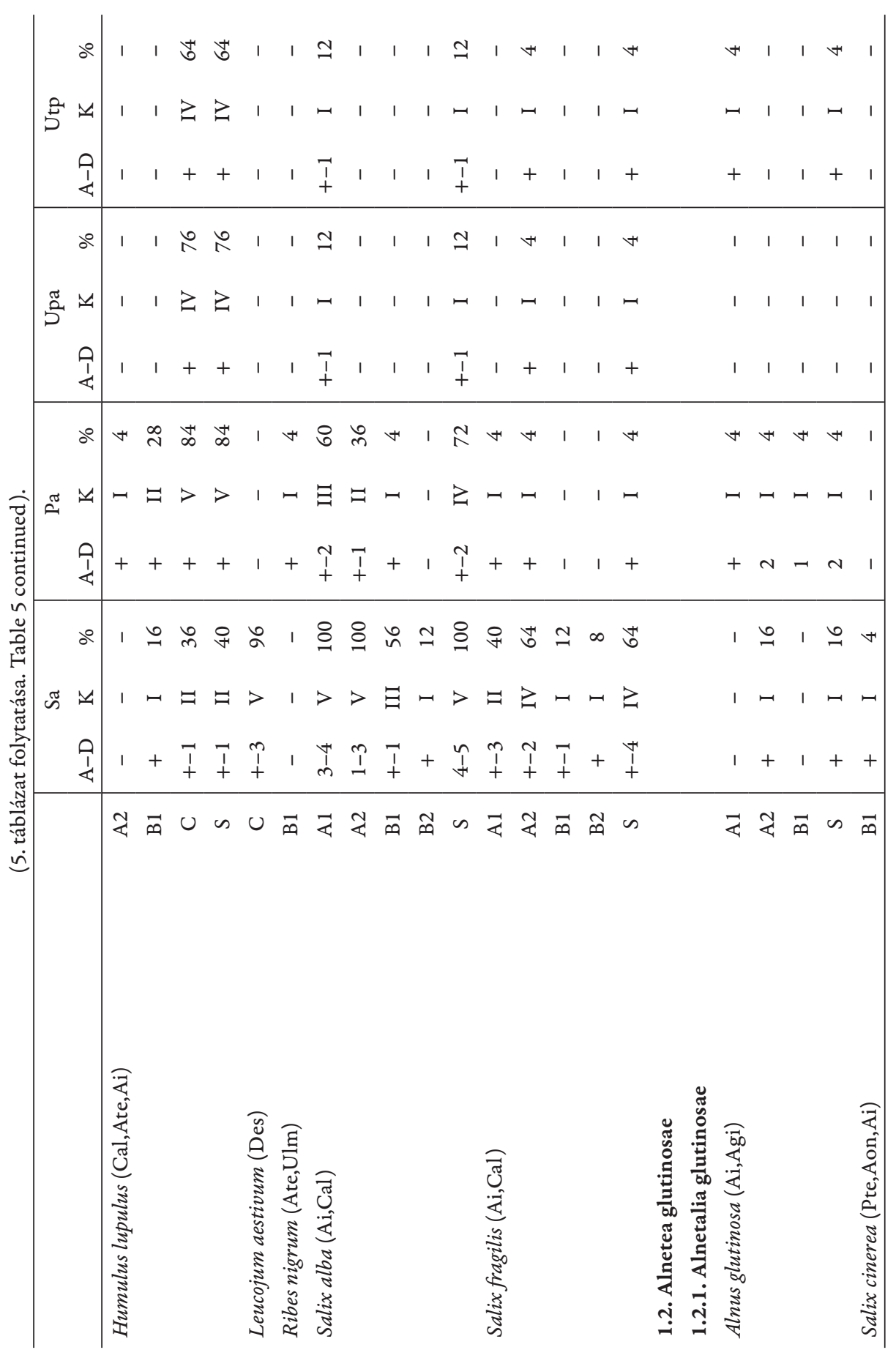




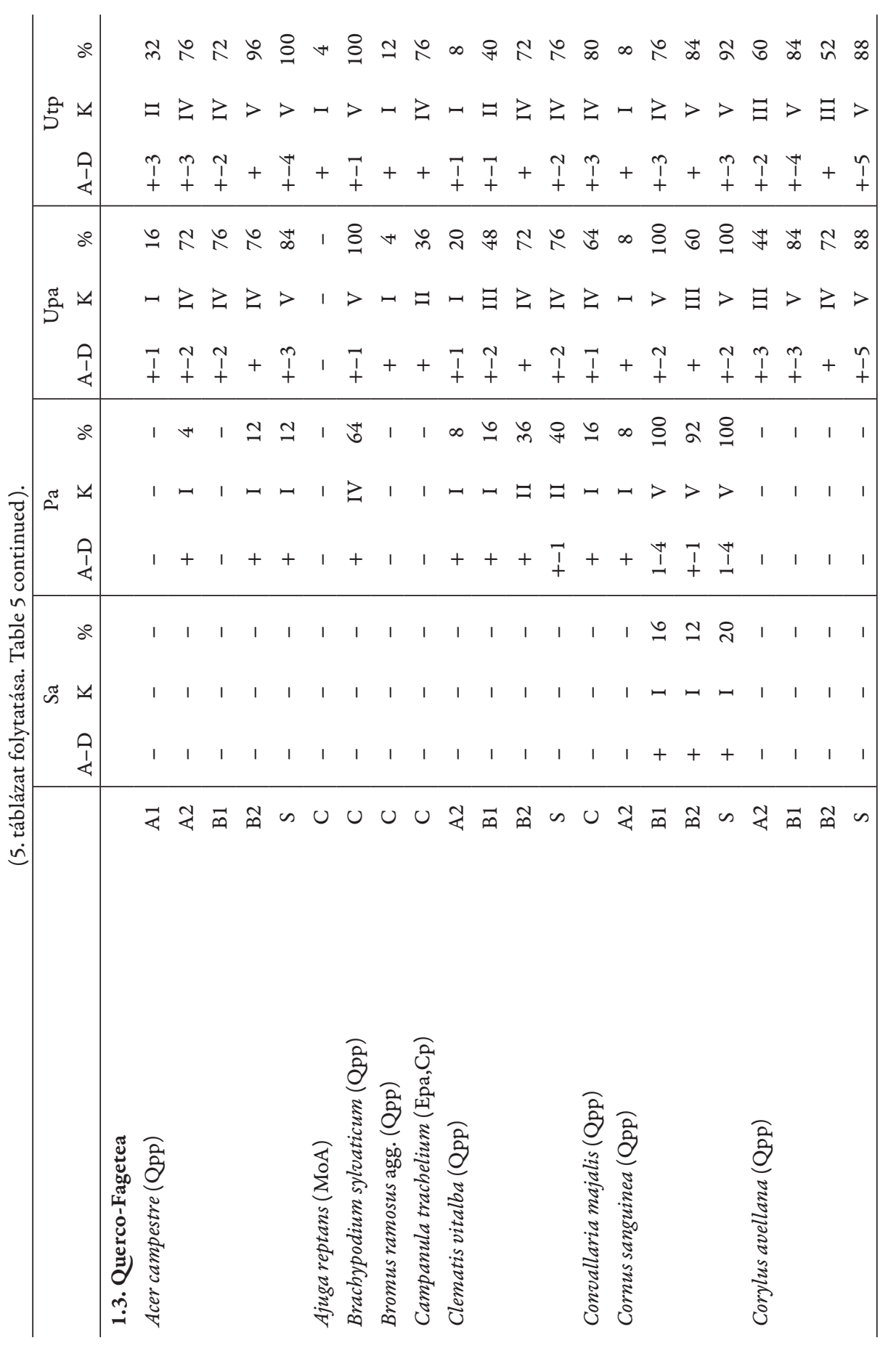




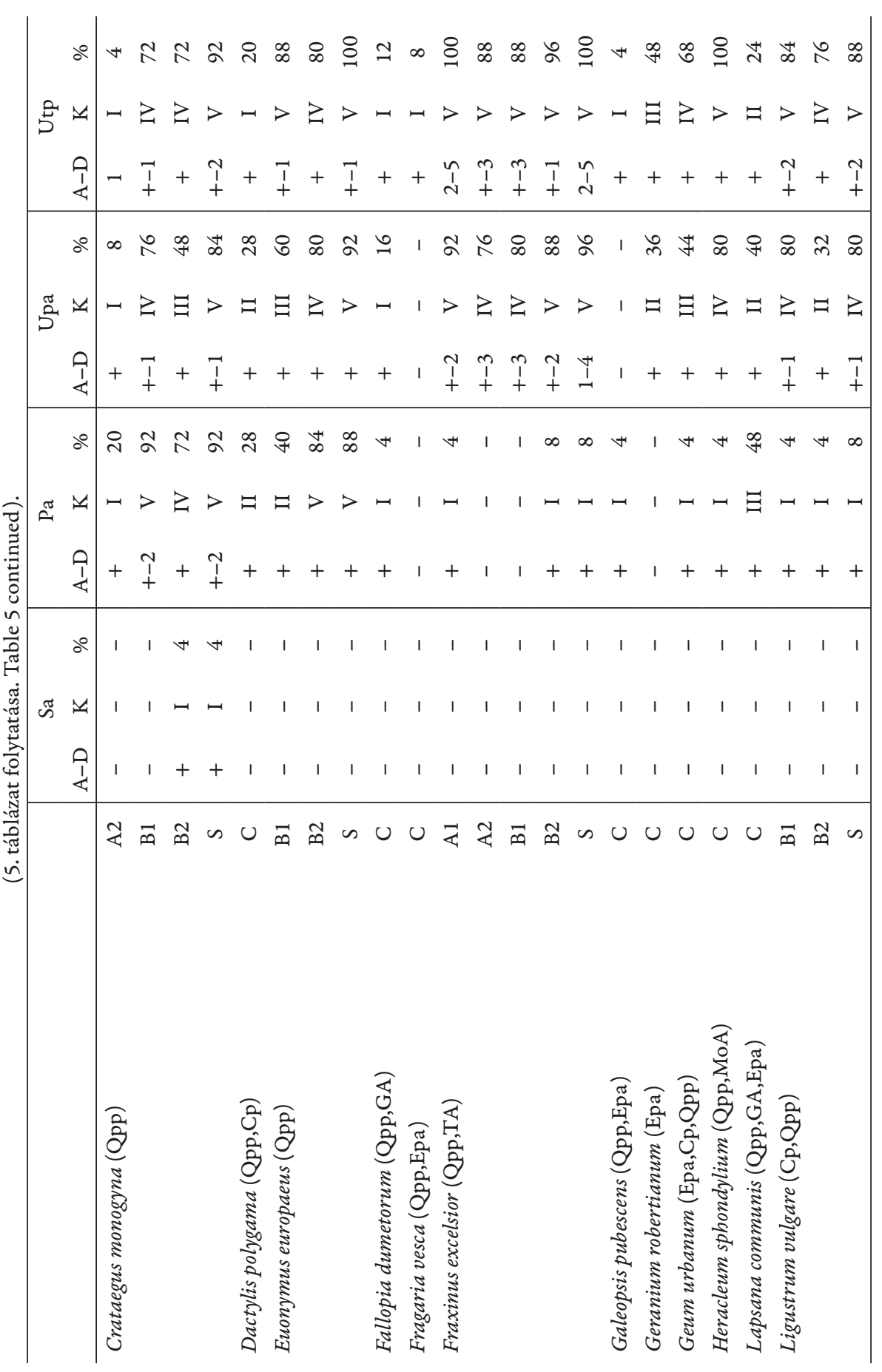




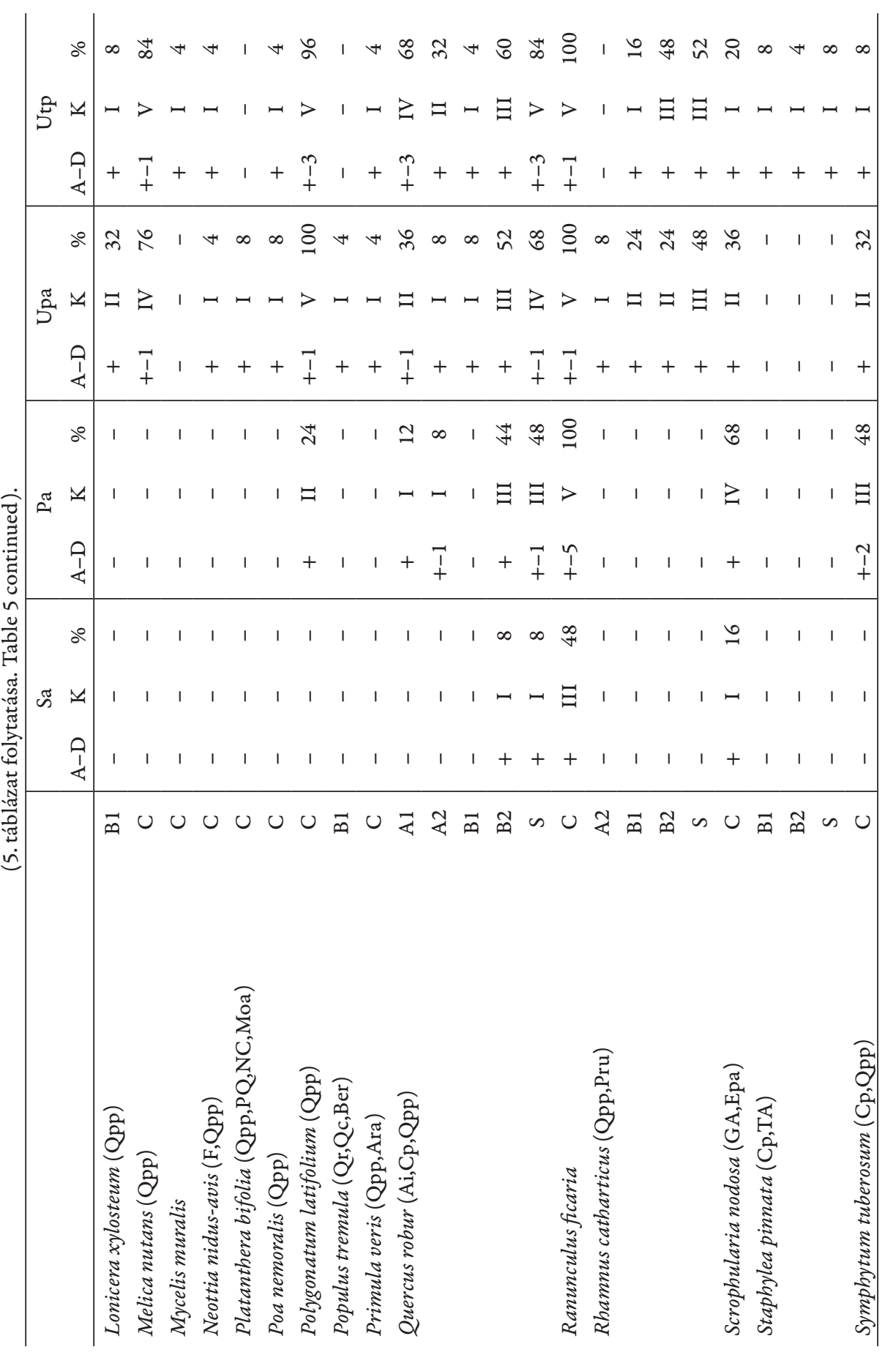




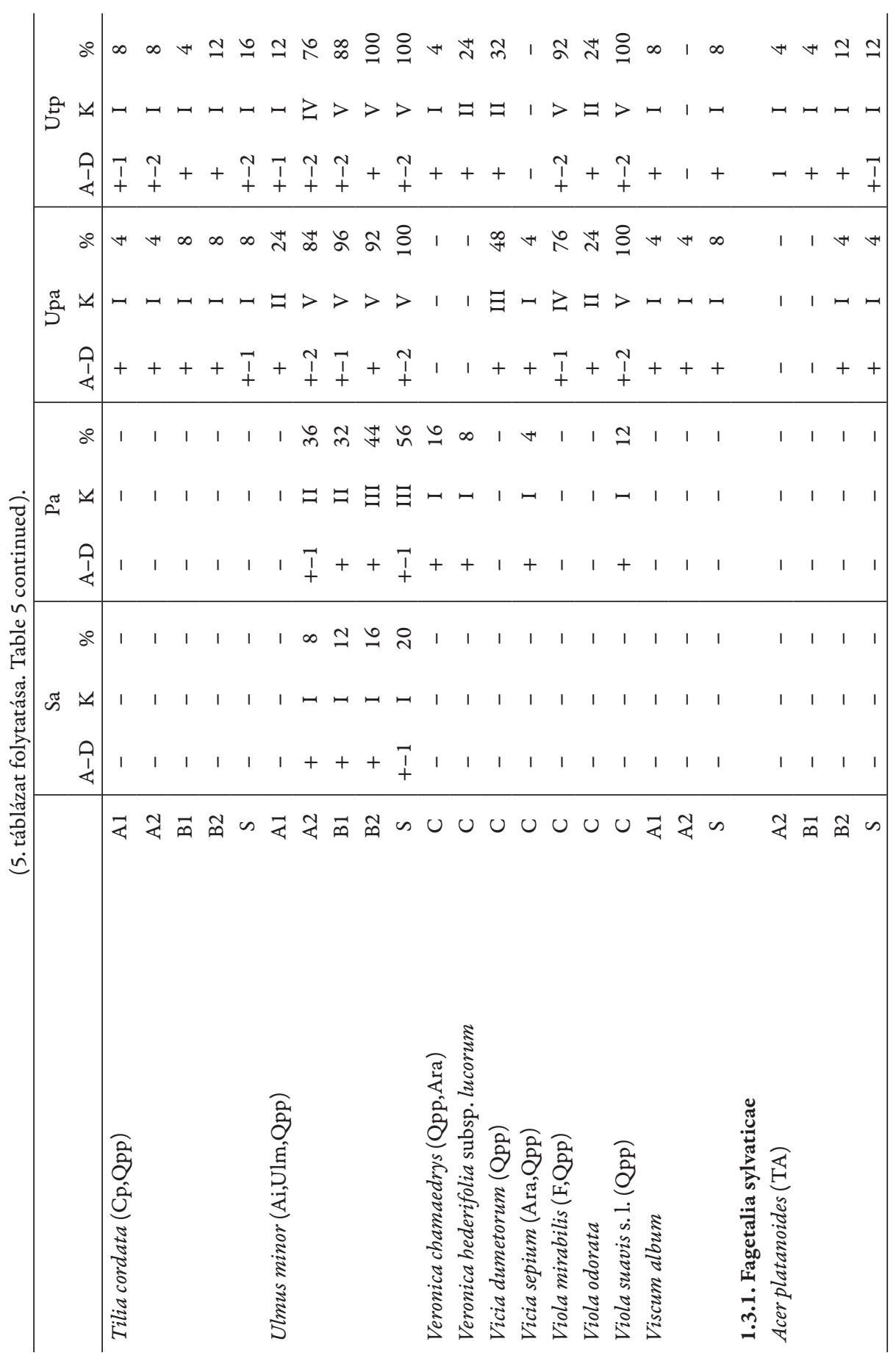




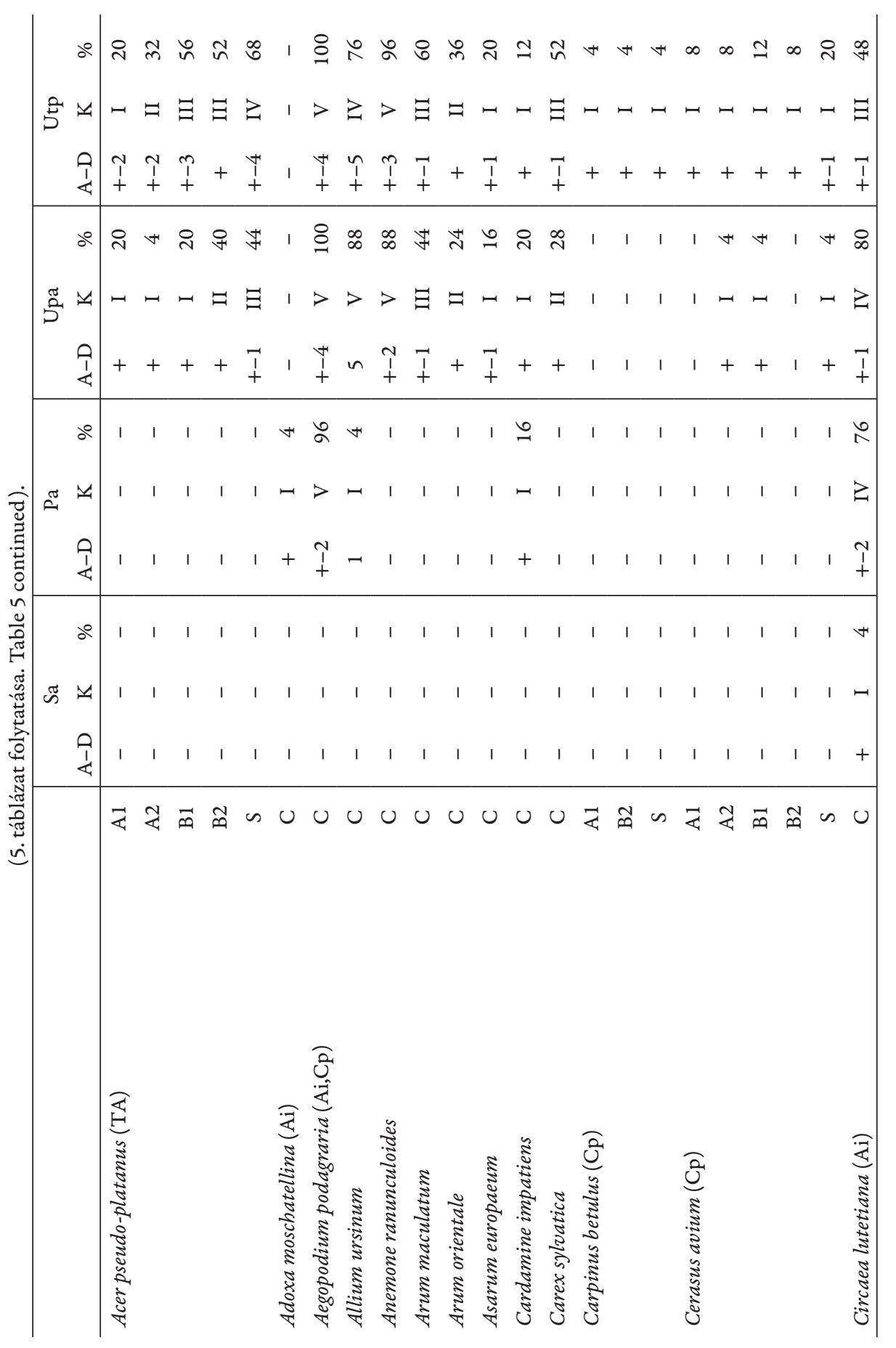




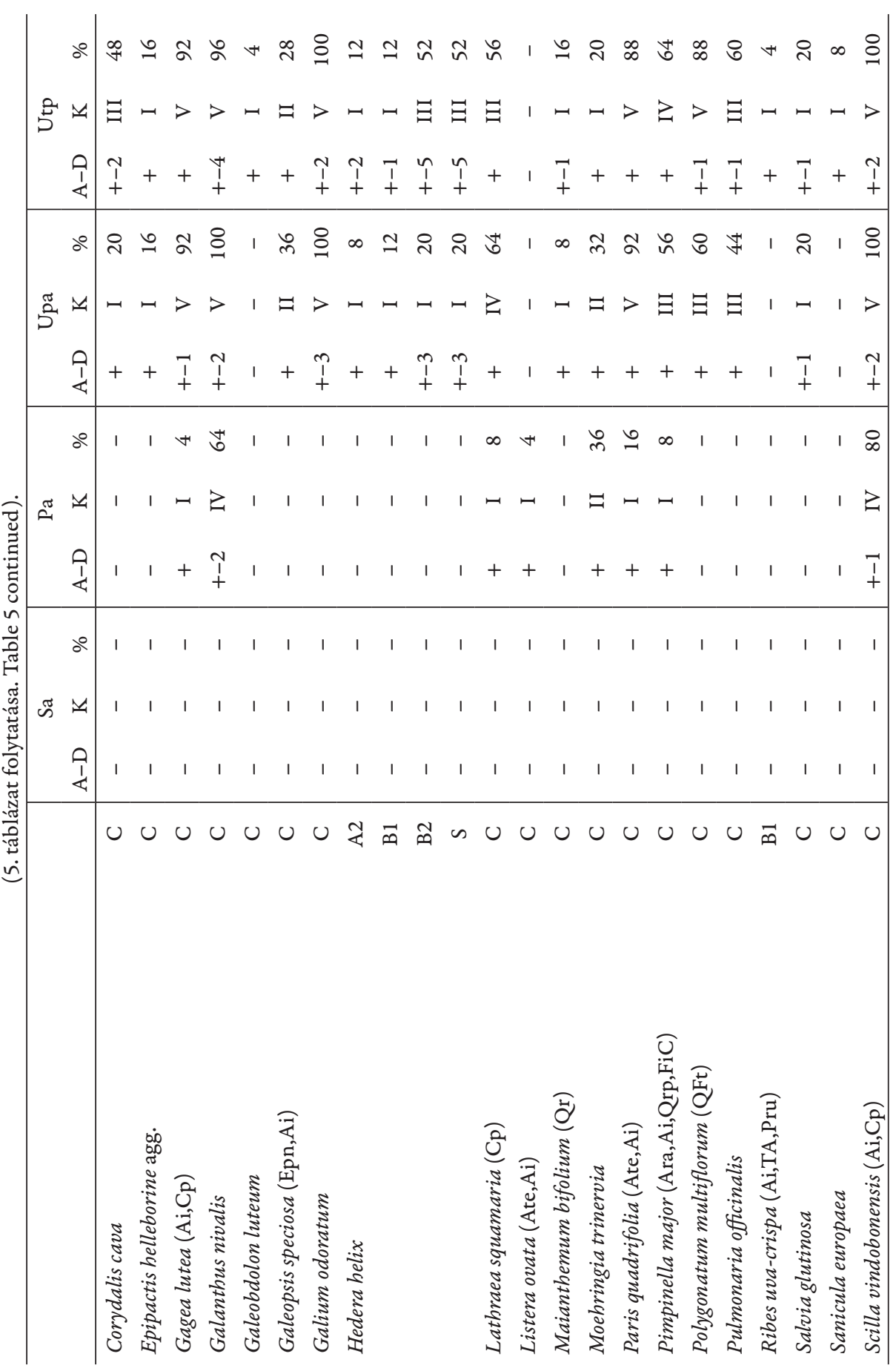




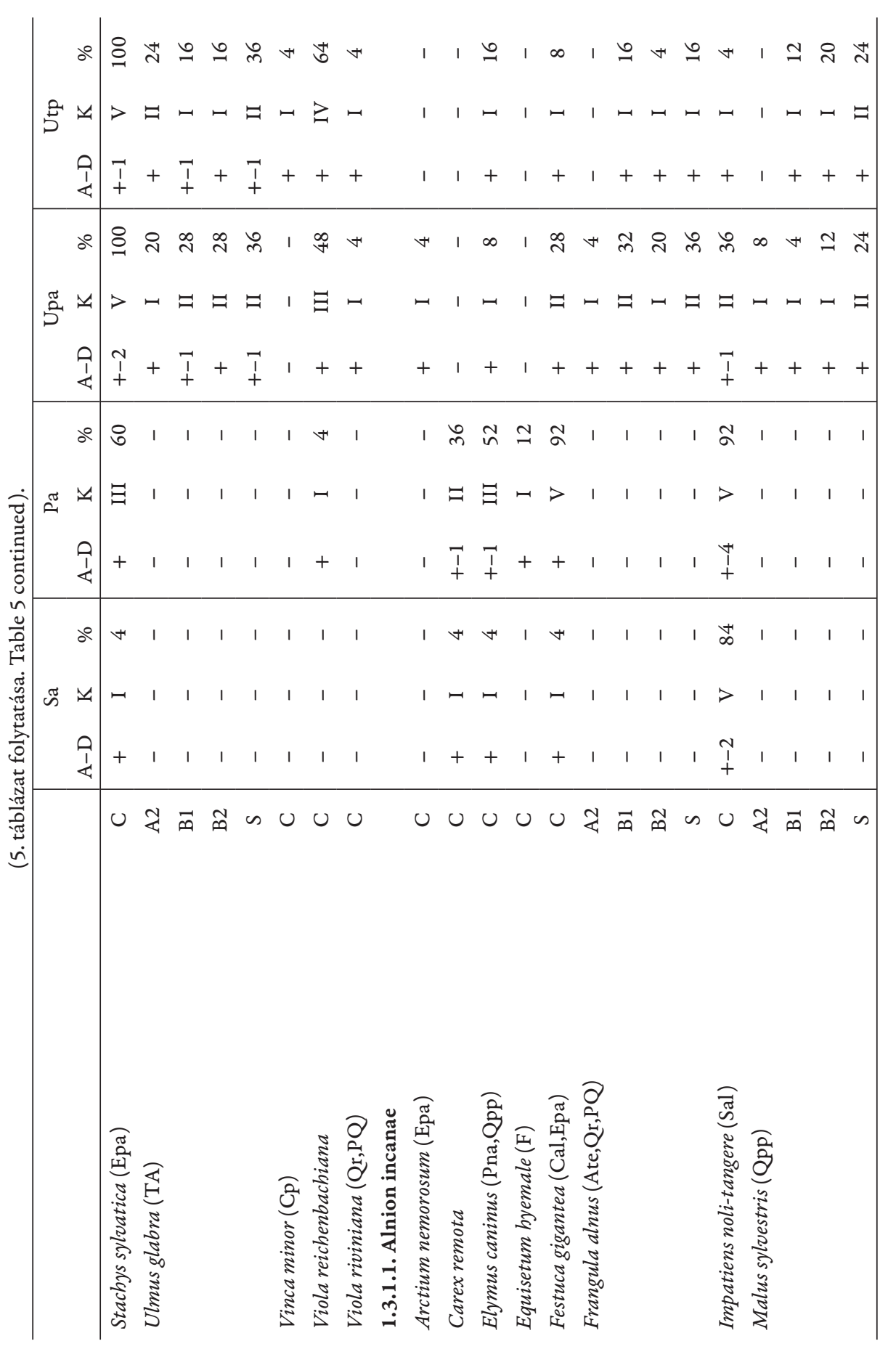




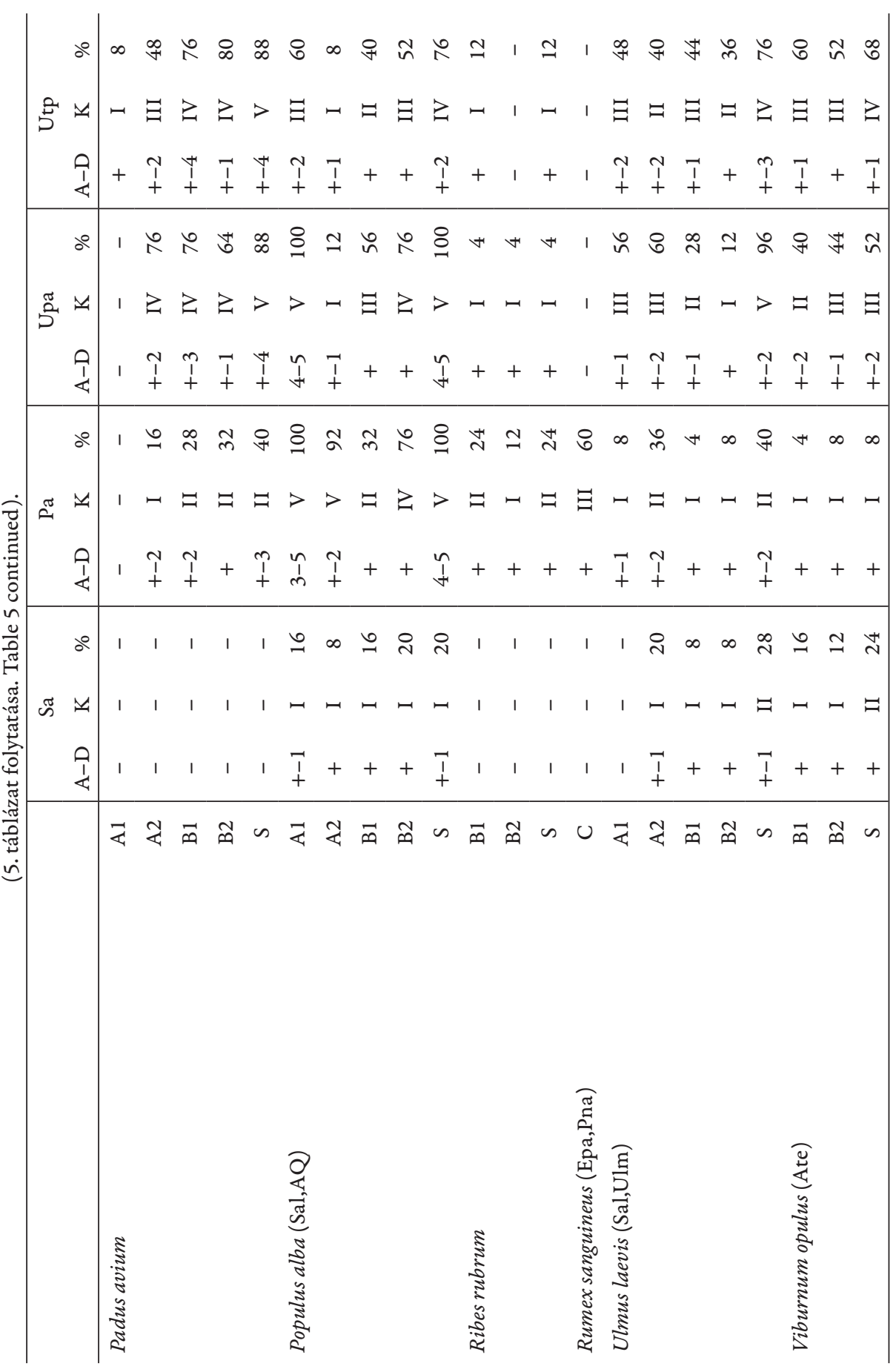


Kevey B.

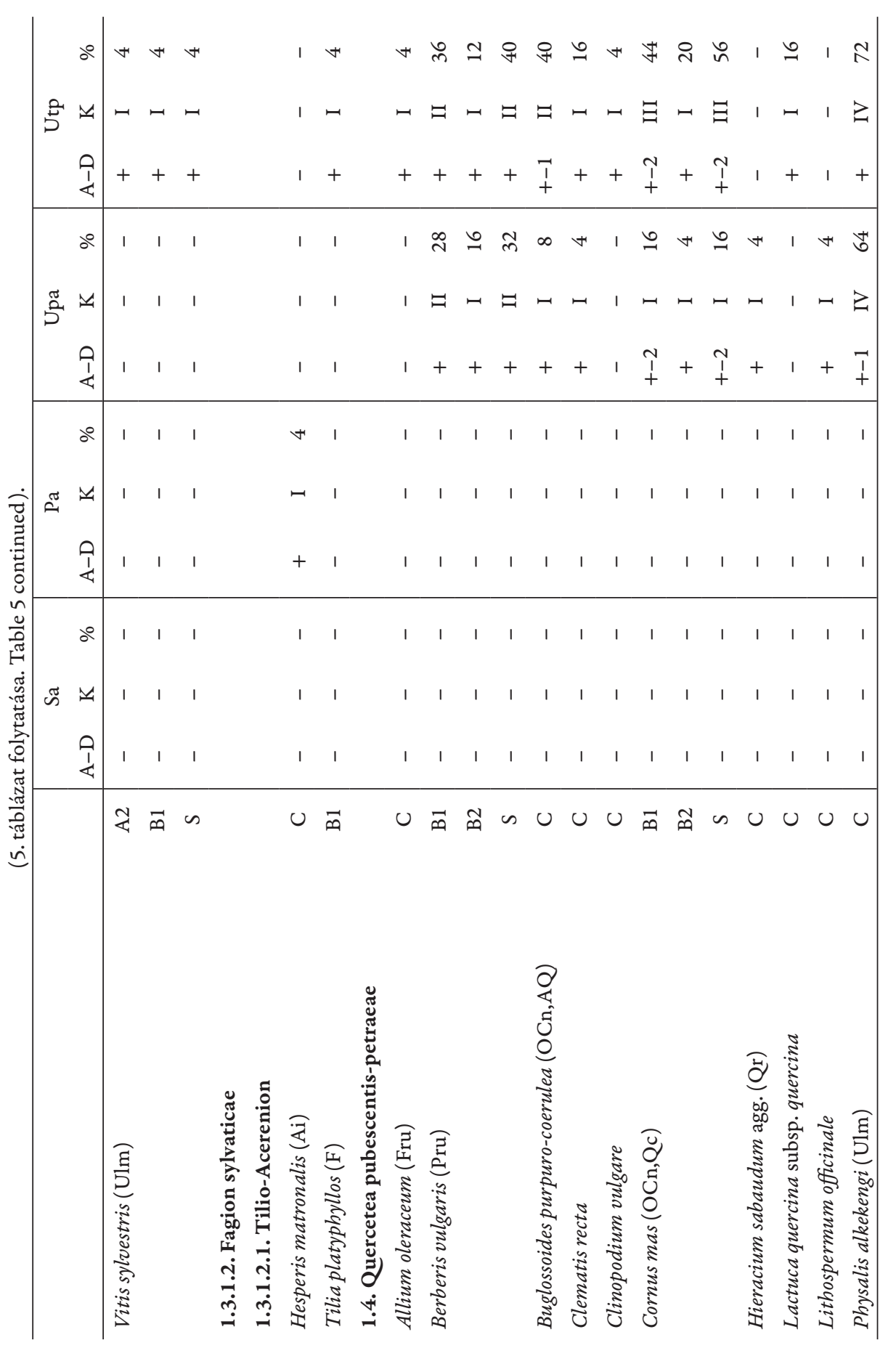




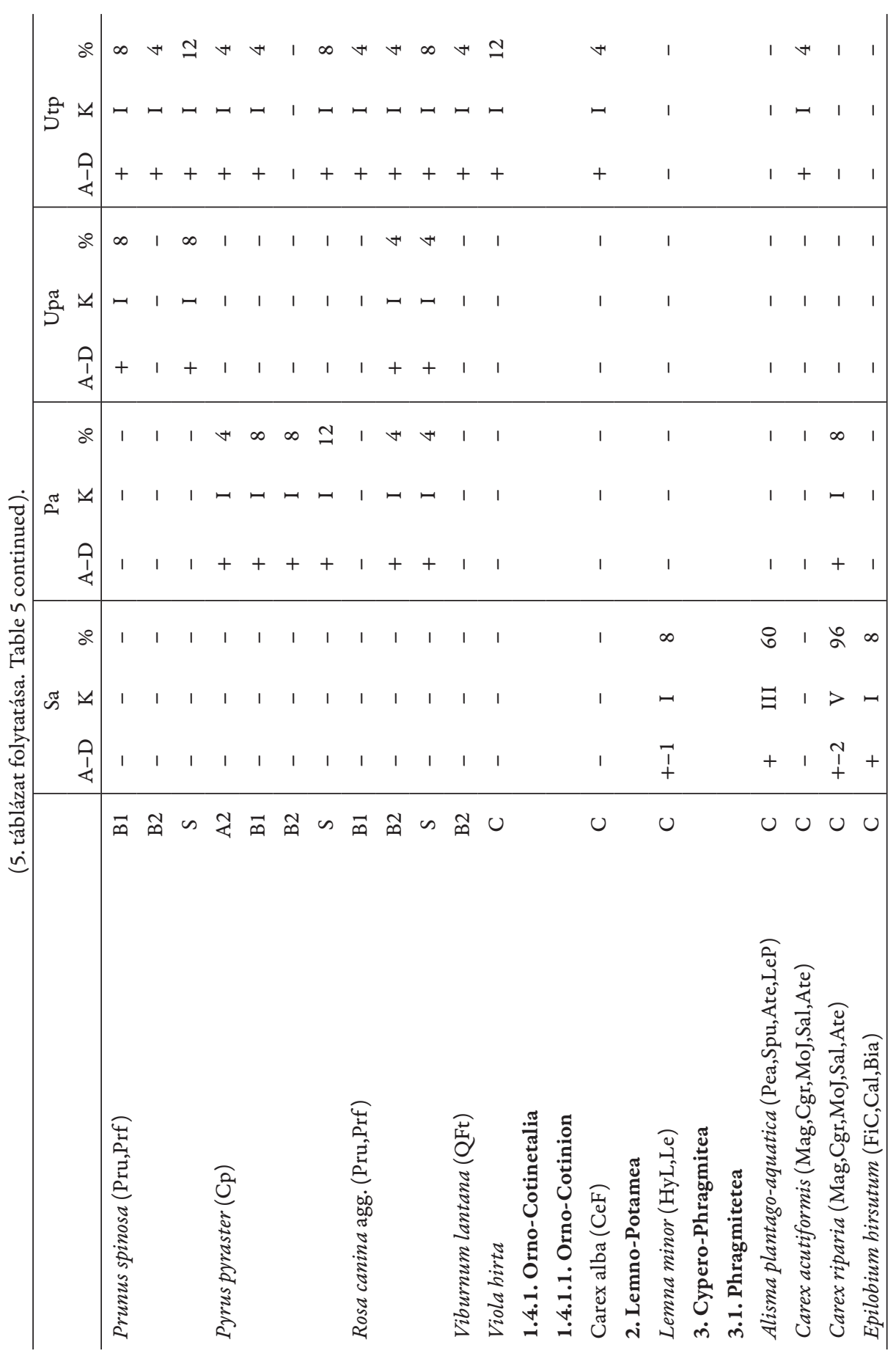


Kevey B.

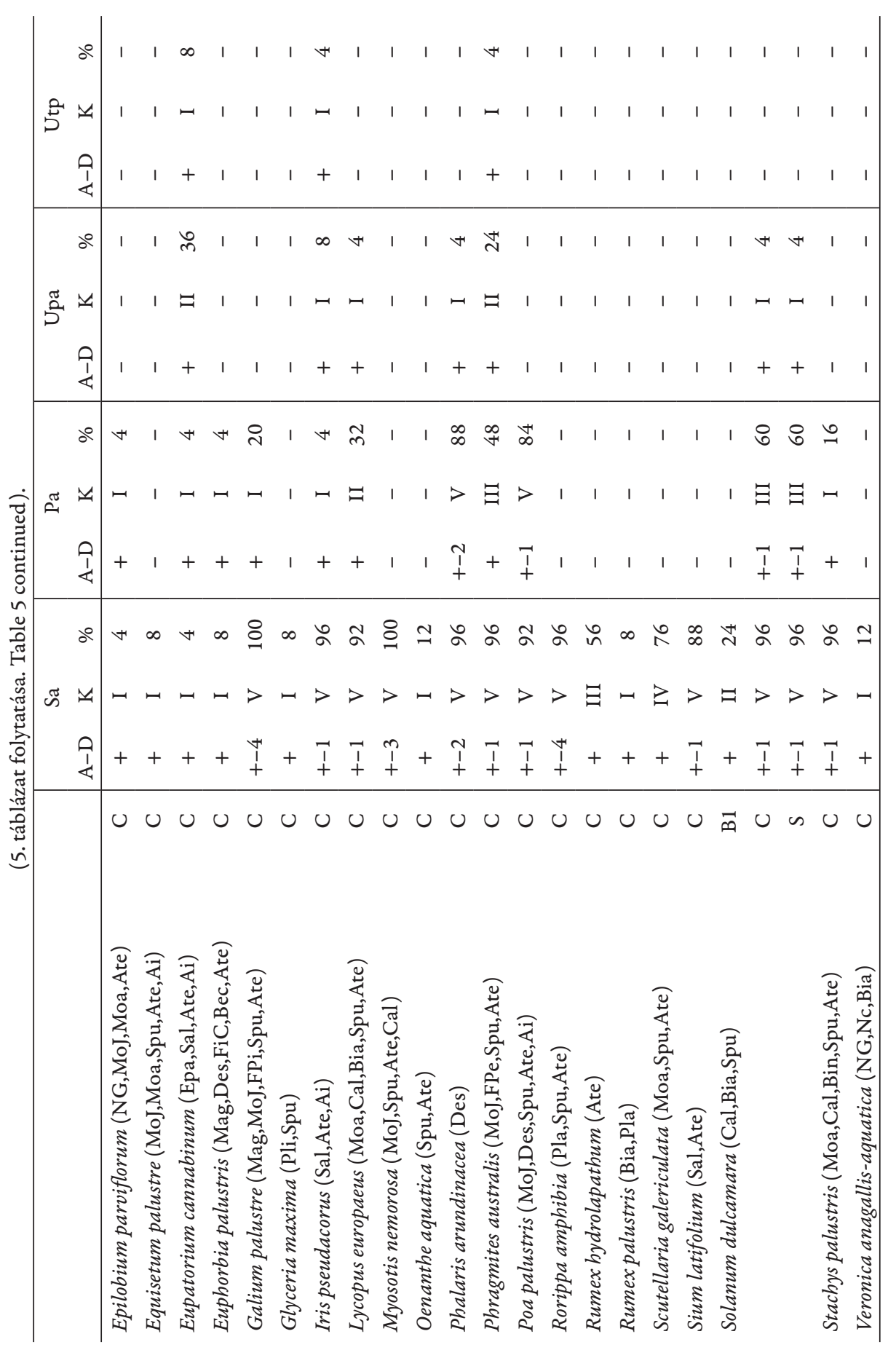




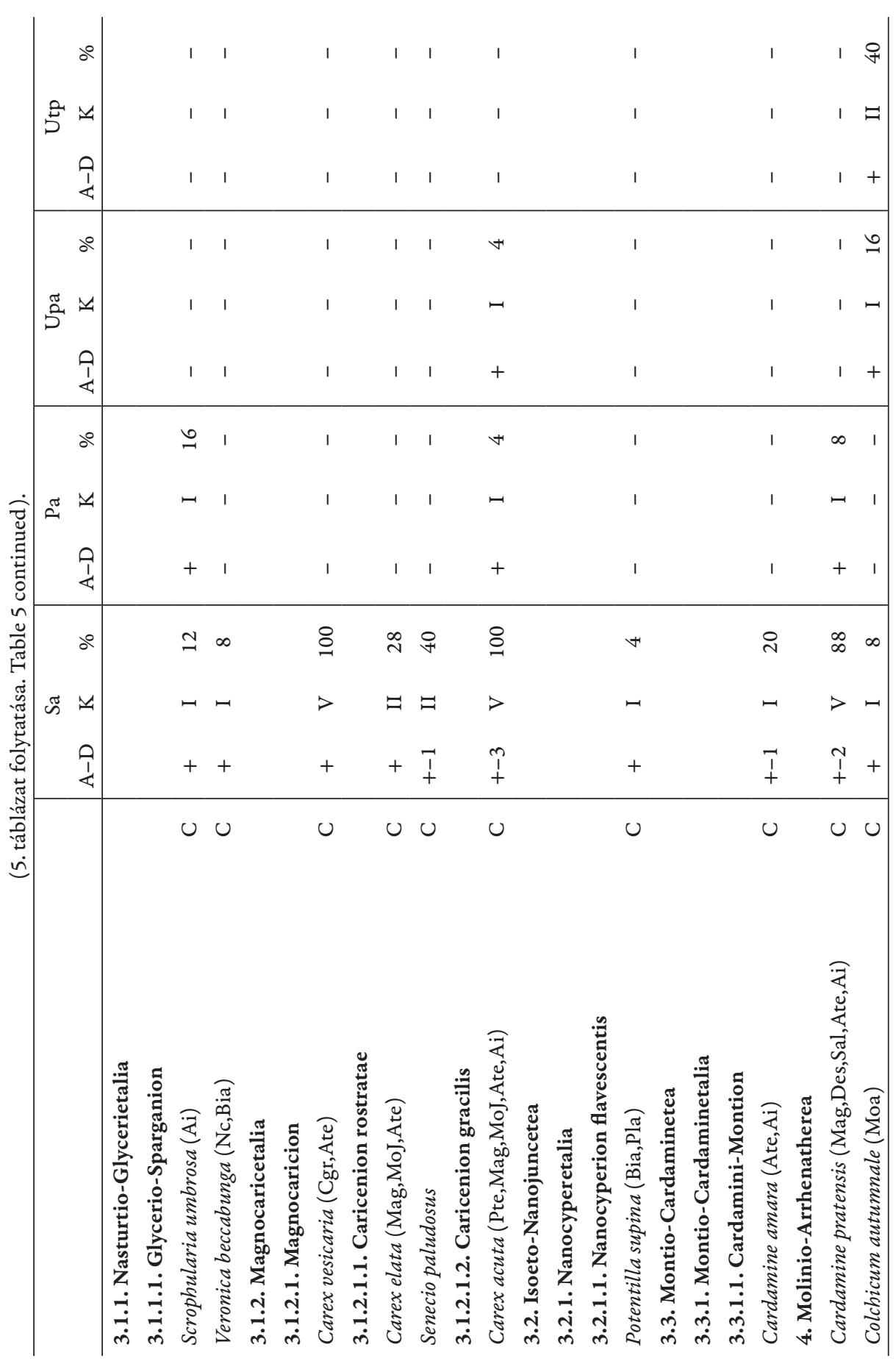




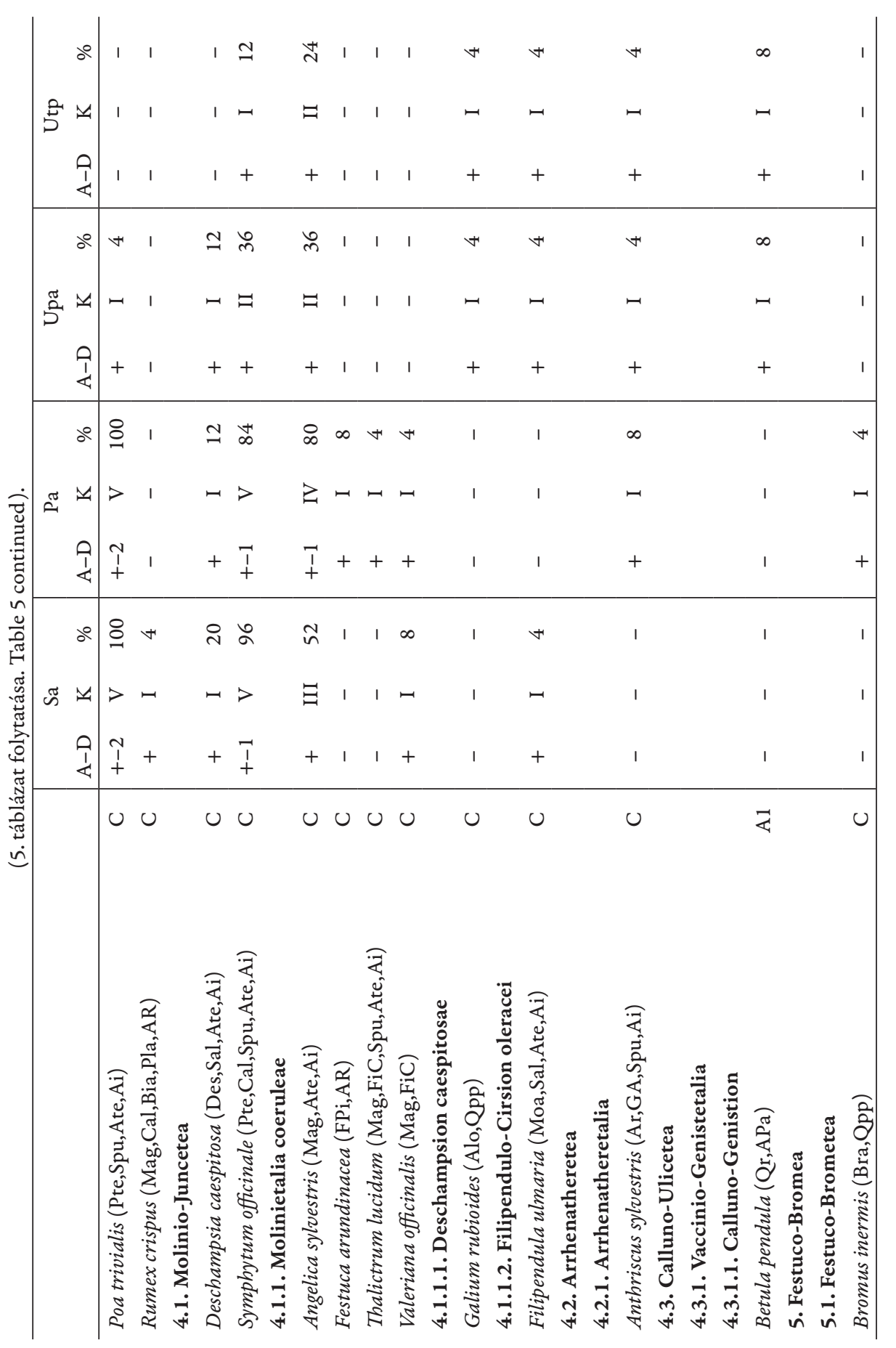




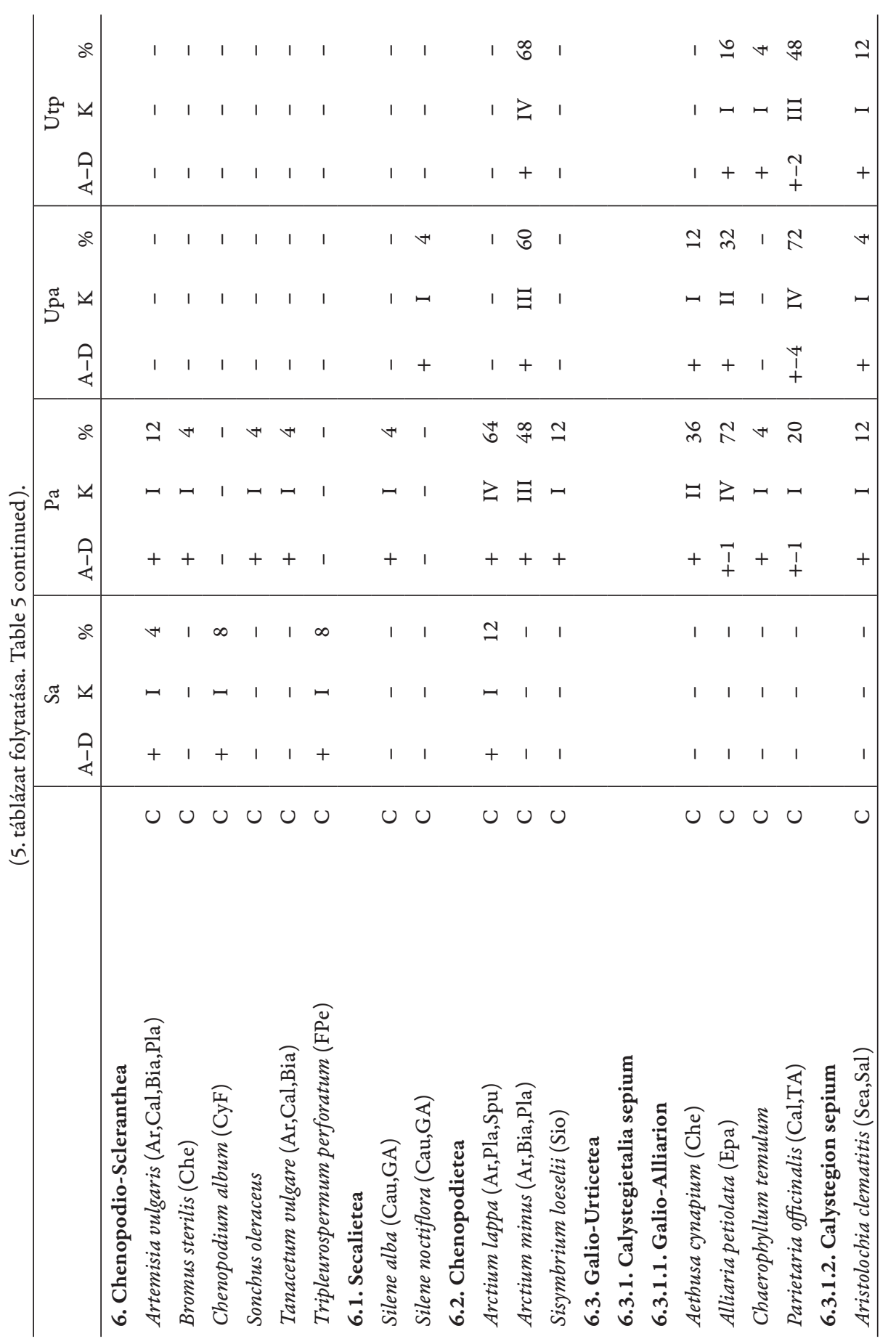


Kevey B.

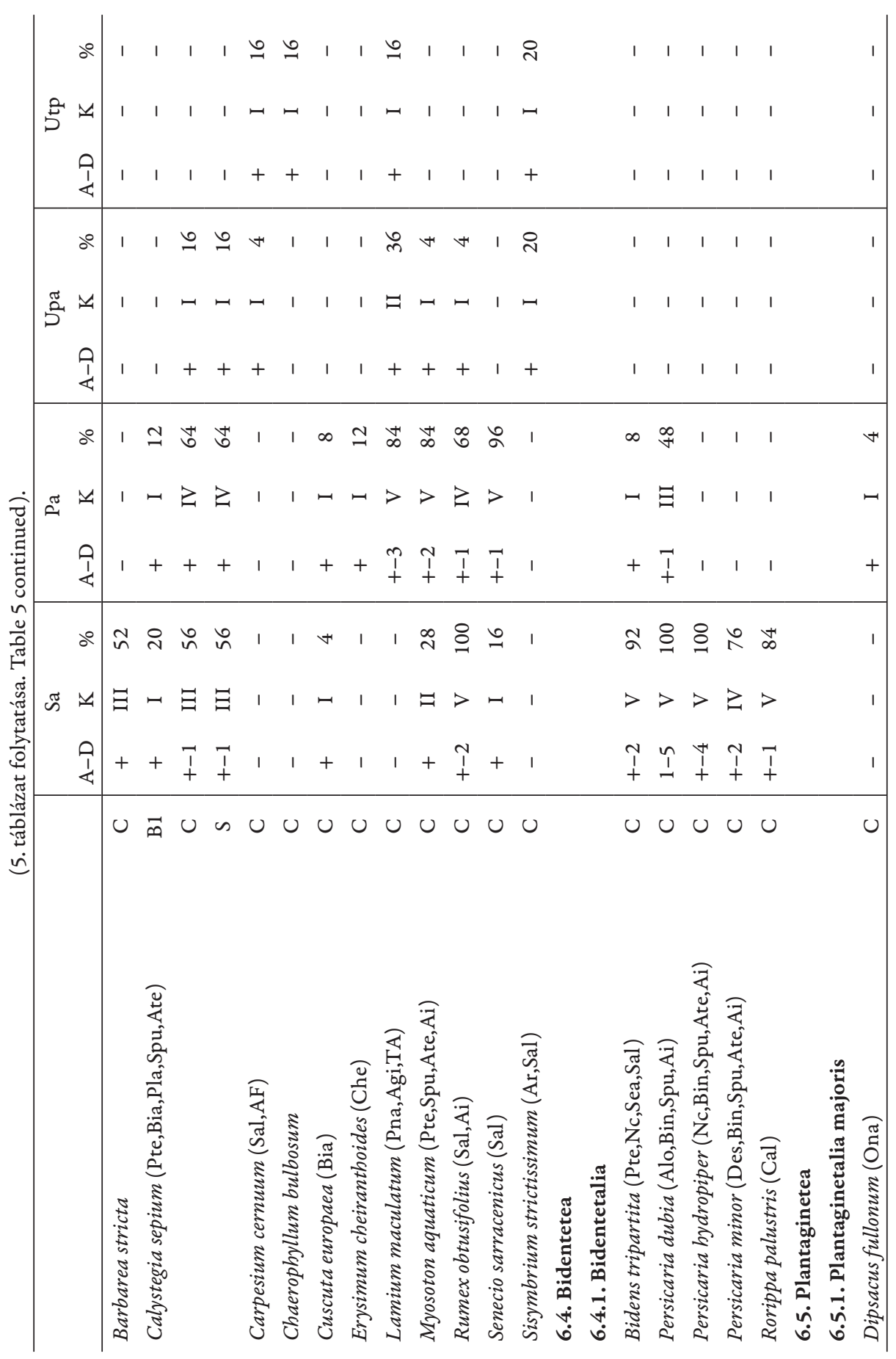




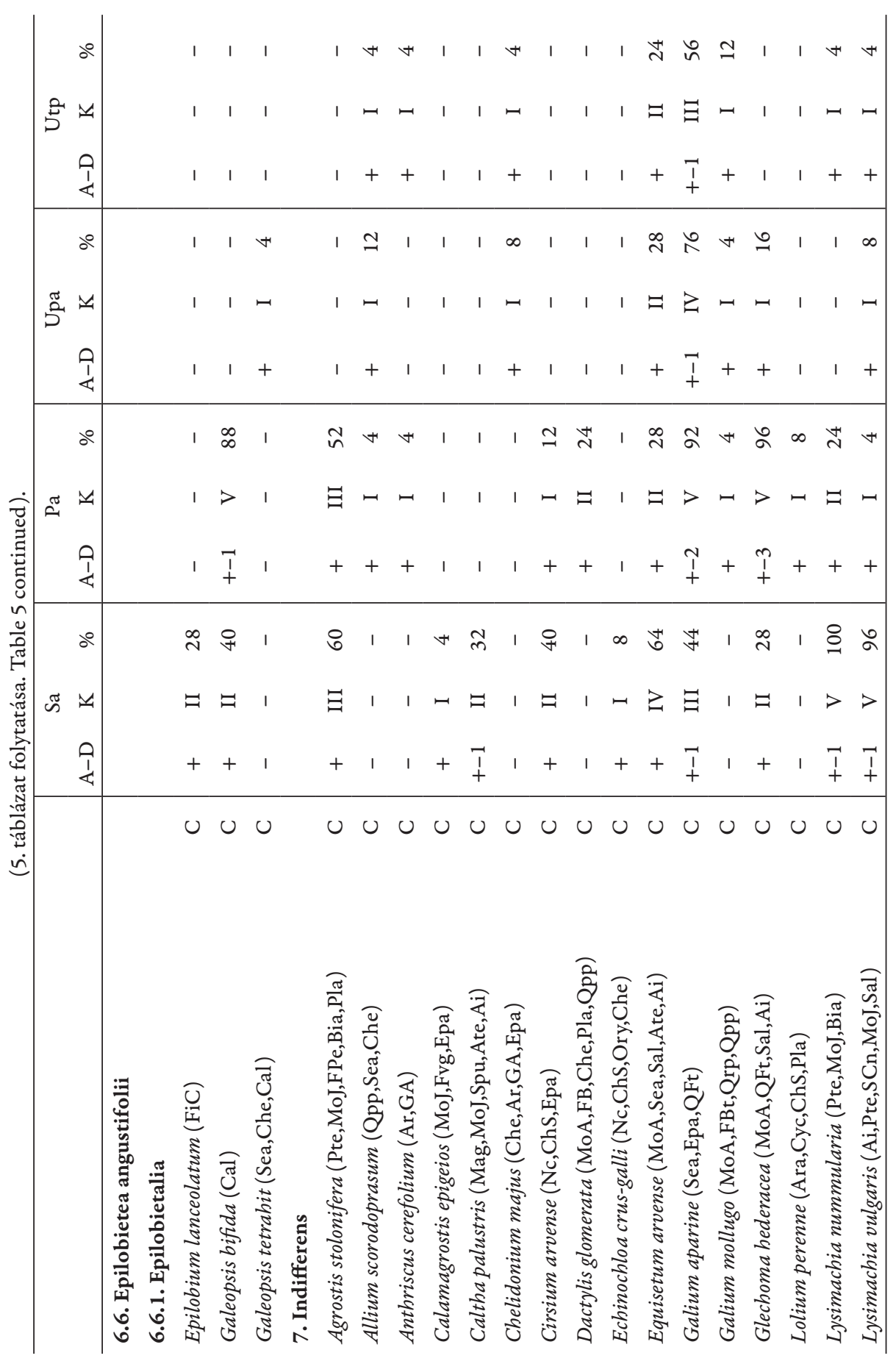




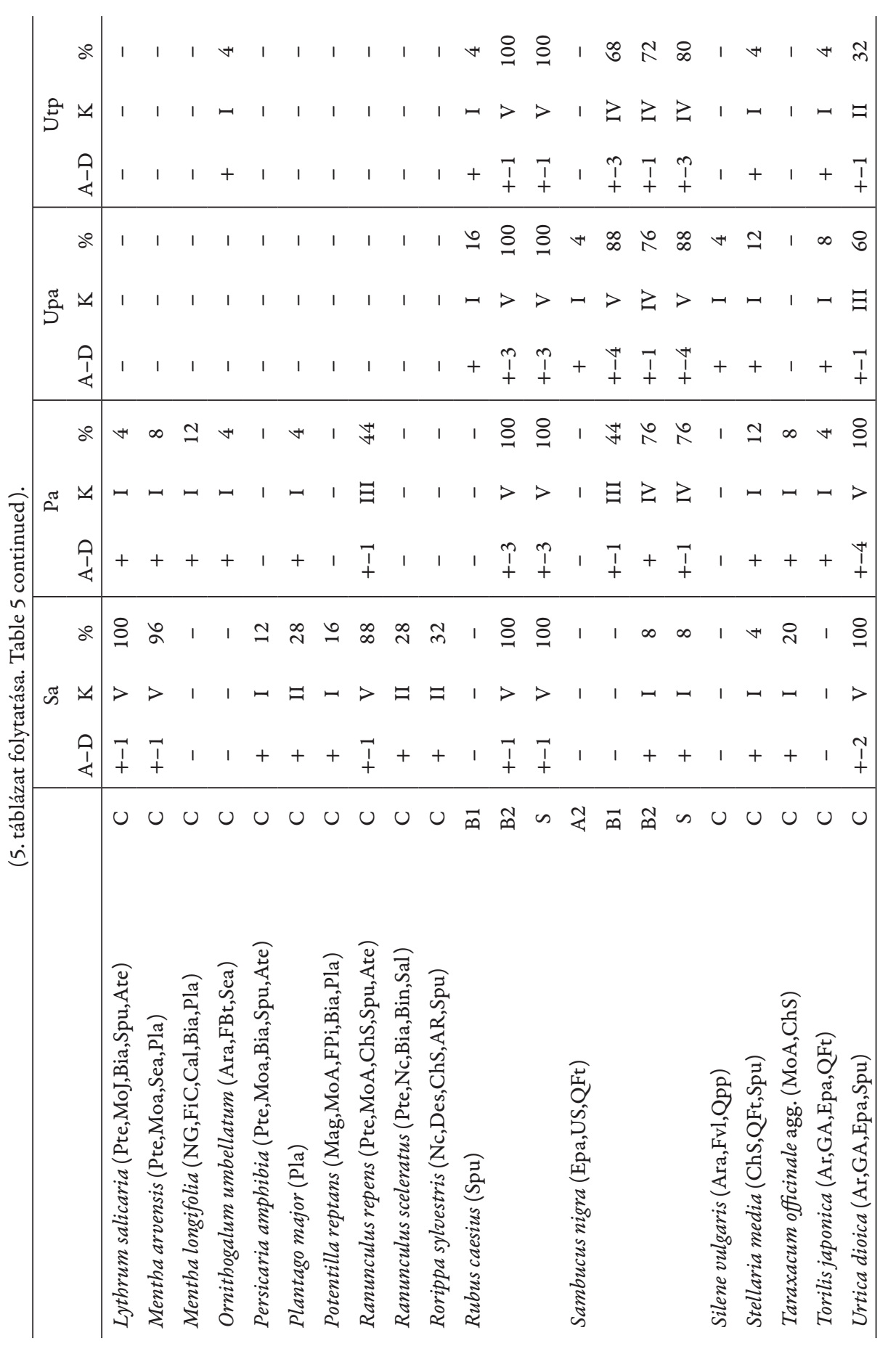




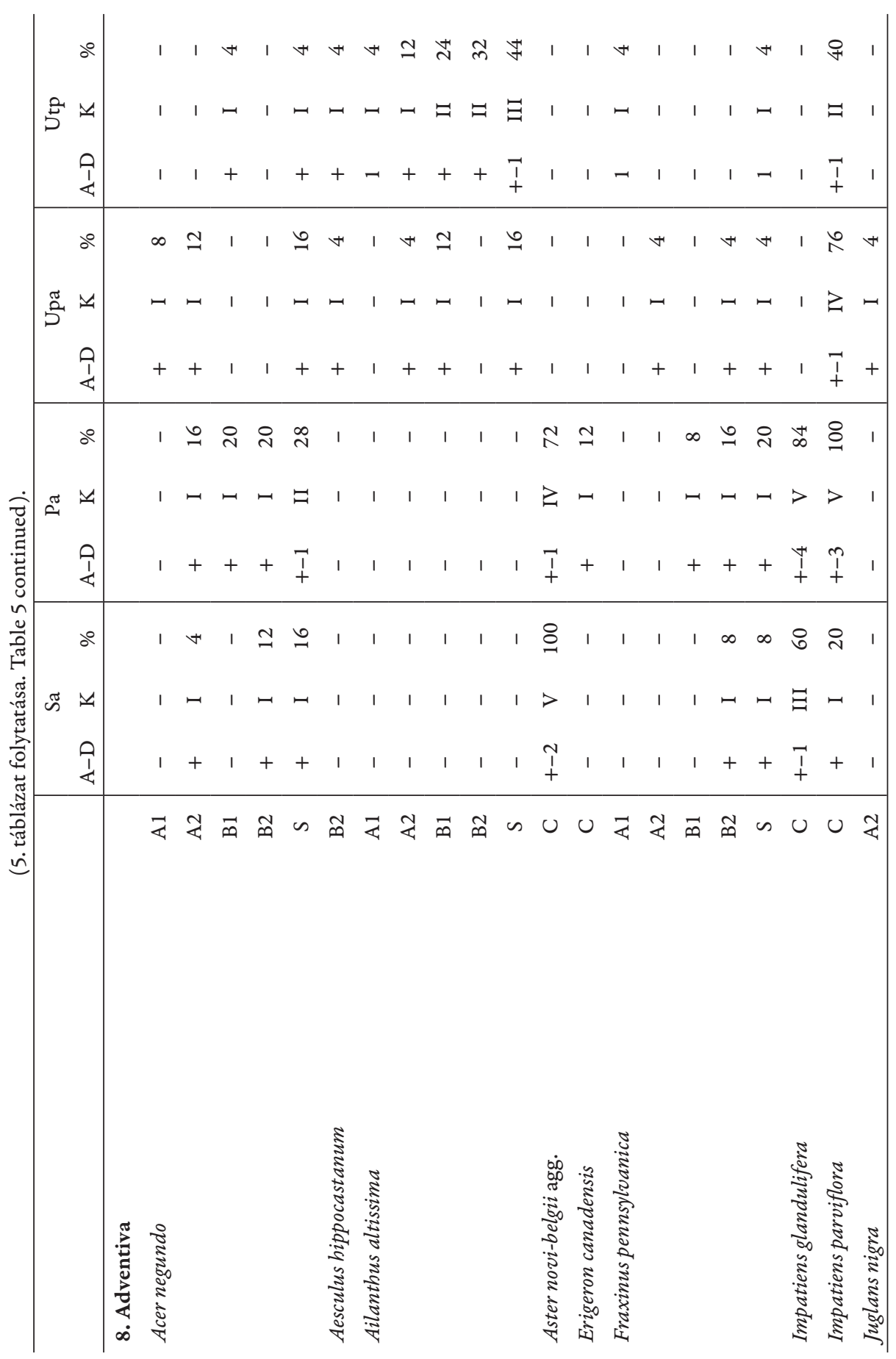




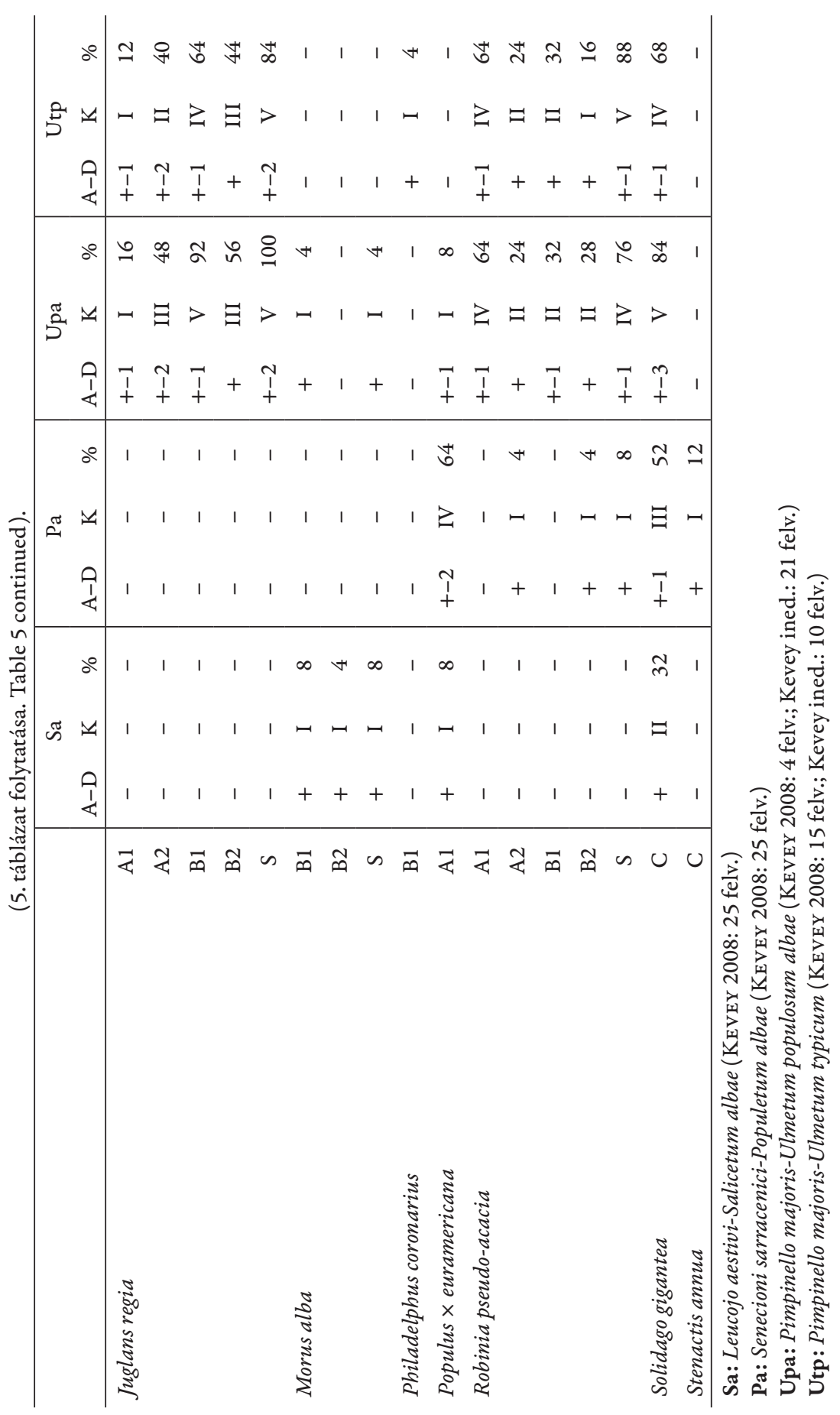


Puha- és keményfás ligeterdők a Szigetközben

6. táblázat. Karakterfajok aránya. Table 6. Proportion of characteristic species.

\begin{tabular}{|c|c|c|c|c|c|c|c|c|}
\hline & \multicolumn{4}{|c|}{ Csoportrészesedés } & \multicolumn{4}{|c|}{ Csoporttömeg } \\
\hline & Sa & $\mathrm{Pa}$ & Upa & Utp & $\mathrm{Sa}$ & $\mathrm{Pa}$ & Upa & Utp \\
\hline Querco-Fagea & 0,0 & 0,0 & 0,0 & 0,0 & 0,0 & 0,0 & 0,0 & 0,0 \\
\hline Salicetea purpureae & 0,0 & 0,0 & 0,0 & 0,0 & 0,0 & 0,0 & 0,0 & 0,0 \\
\hline Salicetalia purpureae & 8,9 & 4,9 & 2,0 & 1,2 & 9,4 & 3,3 & 0,8 & 0,3 \\
\hline Salicion triandrae & 0,2 & 0,0 & 0,0 & 0,0 & 0,0 & 0,0 & 0,0 & 0,0 \\
\hline Salicenion elaeagno-daphnoidis & 0,0 & 0,1 & 0,0 & 0,0 & 0,0 & 0,0 & 0,0 & 0,0 \\
\hline Salicion triandrae s. 1. & 0,2 & 0,1 & 0,0 & 0,0 & 0,0 & 0,0 & 0,0 & 0,0 \\
\hline Salicion albae & 7,4 & 6,5 & 3,7 & 2,5 & 14,8 & 12,8 & 7,1 & 1,3 \\
\hline Populenion nigro-albae & 0,0 & 1,1 & 0,2 & 0,2 & 0,0 & 0,6 & 0,0 & 0,0 \\
\hline Salicion albae s. 1 . & 7,4 & 7,6 & 3,9 & 2,7 & 14,8 & 13,4 & 7,1 & 1,3 \\
\hline Salicetalia purpureae s. 1 . & 16,5 & 12,6 & 5,9 & 3,9 & 24,2 & 16,7 & 7,9 & 1,6 \\
\hline Salicetea purpureae s. 1. & 16,5 & 12,6 & 5,9 & 3,9 & 24,2 & 16,7 & 7,9 & 1,6 \\
\hline Alnetea glutinosae & 0,0 & 0,0 & 0,0 & 0,0 & 0,0 & 0,0 & 0,0 & 0,0 \\
\hline Alnetalia glutinosae & 10,4 & 3,4 & 2,2 & 1,7 & 6,1 & 0,6 & 0,3 & 0,2 \\
\hline Alnetea glutinosae s. 1 . & 10,4 & 3,4 & 2,2 & 1,7 & 6,1 & 0,6 & 0,3 & 0,2 \\
\hline Querco-Fagetea & 1,9 & 9,8 & 17,2 & 18,4 & 0,2 & 21,4 & 12,6 & 21,1 \\
\hline Fagetalia sylvaticae & 0,1 & 5,3 & 18,6 & 21,4 & 0,0 & 1,6 & 31,2 & 26,7 \\
\hline Alnion incanae & 8,6 & 12,4 & 9,6 & 8,2 & 18,4 & 15,4 & 14,6 & 9,8 \\
\hline Alnenion glutinosae-incanae & 0,2 & 0,9 & 0,6 & 0,2 & 0,0 & 1,0 & 0,1 & 0,1 \\
\hline Ulmenion & 0,3 & 0,9 & 1,7 & 1,7 & 0,1 & 0,2 & 0,7 & 0,9 \\
\hline Alnion incanae s. 1 . & 9,1 & 14,2 & 11,9 & 10,1 & 18,5 & 16,6 & 15,4 & 10,8 \\
\hline Fagion sylvaticae & 0,0 & 0,0 & 0,0 & 0,0 & 0,0 & 0,0 & 0,0 & 0,0 \\
\hline Carpinenion betuli & 0,0 & 2,2 & 3,8 & 4,3 & 0,0 & 1,1 & 2,1 & 4,1 \\
\hline Tilio-Acerenion & 0,0 & 0,6 & 1,8 & 2,0 & 0,0 & 0,6 & 3,7 & 9,0 \\
\hline Fagion sylvaticae s. 1 . & 0,0 & 2,8 & 5,6 & 6,3 & 0,0 & 1,7 & 5,8 & 13,1 \\
\hline Aremonio-Fagion & 0,0 & 0,0 & 0,0 & 0,1 & 0,0 & 0,0 & 0,0 & 0,0 \\
\hline Fagetalia sylvaticae s. 1 . & 9,2 & 22,3 & 36,1 & 37,9 & 18,5 & 19,9 & 52,4 & 50,6 \\
\hline Quercetalia roboris & 0,0 & 0,0 & 0,3 & 0,3 & 0,0 & 0,0 & 0,0 & 0,0 \\
\hline Quercion robori-petraeae & 0,0 & 0,0 & 0,2 & 0,3 & 0,0 & 0,0 & 0,0 & 0,0 \\
\hline Quercetalia roboris s. 1. & 0,0 & 0,0 & 0,5 & 0,6 & 0,0 & 0,0 & 0,0 & 0,0 \\
\hline Querco-Fagetea s. 1. & 11,1 & 32,1 & 53,8 & 56,9 & 18,7 & 41,3 & 65,0 & 71,7 \\
\hline Quercetea pubescentis-petraeae & 0,4 & 6,6 & 14,4 & 16,2 & 0,1 & 9,1 & 10,9 & 20,4 \\
\hline Orno-Cotinetalia & 0,0 & 0,0 & 0,0 & 0,0 & 0,0 & 0,0 & 0,0 & 0,0 \\
\hline Orno-Cotinion & 0,0 & 0,0 & 0,1 & 0,6 & 0,0 & 0,0 & 0,1 & 0,3 \\
\hline Orno-Cotinetalia s. 1. & 0,0 & 0,0 & 0,1 & 0,6 & 0,0 & 0,0 & 0,1 & 0,3 \\
\hline Quercetalia cerridis & 0,0 & 0,0 & 0,1 & 0,3 & 0,0 & 0,0 & 0,1 & 0,2 \\
\hline Aceri tatarici-Quercion & 0,1 & 0,7 & 0,6 & 0,7 & 0,1 & 9,5 & 6,6 & 0,7 \\
\hline Quercetalia cerridis s. 1 . & 0,1 & 0,7 & 0,7 & 1,0 & 0,1 & 9,5 & 6,7 & 0,9 \\
\hline Prunetalia spinosae & 0,0 & 0,0 & 0,6 & 0,8 & 0,0 & 0,0 & 0,1 & 0,1 \\
\hline Prunion fruticosae & 0,0 & 0,0 & 0,1 & 0,1 & 0,0 & 0,0 & 0,0 & 0,0 \\
\hline Prunetalia spinosae s. 1. & 0,0 & 0,0 & 0,7 & 0,9 & 0,0 & 0,0 & 0,1 & 0,1 \\
\hline Quercetea pubescentis-petraeae s. 1. & 0,5 & 7,3 & 15,9 & 18,7 & 0,2 & 18,6 & 17,8 & 21,7 \\
\hline
\end{tabular}


Kevey B.

(6. táblázat folytatása. Table 6 continued.)

\begin{tabular}{|c|c|c|c|c|c|c|c|c|}
\hline & \multicolumn{4}{|c|}{ Csoportrészesedés } & \multicolumn{4}{|c|}{ Csoporttömeg } \\
\hline & $\mathrm{Sa}$ & $\mathrm{Pa}$ & Upa & Utp & $\mathrm{Sa}$ & $\mathrm{Pa}$ & Upa & Utp \\
\hline Querco-Fagea s. 1. & 38,5 & 55,4 & 77,8 & 81,2 & 49,2 & 77,2 & 91,0 & 95,2 \\
\hline Abieti-Piceea & 0,0 & 0,0 & 0,0 & 0,0 & 0,0 & 0,0 & 0,0 & 0,0 \\
\hline Vaccinio-Piceetea & 0,0 & 0,0 & 0,0 & 0,0 & 0,0 & 0,0 & 0,0 & 0,0 \\
\hline Pino-Quercetalia & 0,0 & 0,0 & 0,0 & 0,0 & 0,0 & 0,0 & 0,0 & 0,0 \\
\hline Pino-Quercion & 0,0 & 0,0 & 0,2 & 0,1 & 0,0 & 0,0 & 0,0 & 0,0 \\
\hline Pino-Quercetalia s. 1. & 0,0 & 0,0 & 0,2 & 0,1 & 0,0 & 0,0 & 0,0 & 0,0 \\
\hline Vaccinio-Piceetea s. 1. & 0,0 & 0,0 & 0,2 & 0,1 & 0,0 & 0,0 & 0,0 & 0,0 \\
\hline Abieti-Piceea s. 1. & 0,0 & 0,0 & 0,2 & 0,1 & 0,0 & 0,0 & 0,0 & 0,0 \\
\hline Lemno-Potamea & 0,3 & 0,0 & 0,0 & 0,0 & 0,0 & 0,0 & 0,0 & 0,0 \\
\hline Hydrochari-Lemnetea & 0,0 & 0,0 & 0,0 & 0,0 & 0,0 & 0,0 & 0,0 & 0,0 \\
\hline Hydrocharietalia & 0,1 & 0,0 & 0,0 & 0,0 & 0,0 & 0,0 & 0,0 & 0,0 \\
\hline Lemnion minoris & 0,1 & 0,0 & 0,0 & 0,0 & 0,0 & 0,0 & 0,0 & 0,0 \\
\hline Hydrocharietalia s. 1. & 0,2 & 0,0 & 0,0 & 0,0 & 0,0 & 0,0 & 0,0 & 0,0 \\
\hline Hydrochari-Lemnetea s. 1. & 0,2 & 0,0 & 0,0 & 0,0 & 0,0 & 0,0 & 0,0 & 0,0 \\
\hline Potametea & 0,2 & 0,0 & 0,0 & 0,0 & 0,0 & 0,0 & 0,0 & 0,0 \\
\hline Lemno-Potamea s. 1. & 0,7 & 0,0 & 0,0 & 0,0 & 0,0 & 0,0 & 0,0 & 0,0 \\
\hline Cypero-Phragmitea & 0,0 & 0,0 & 0,0 & 0,0 & 0,0 & 0,0 & 0,0 & 0,0 \\
\hline Phragmitetea & 10,9 & 3,7 & 0,5 & 0,1 & 6,1 & 0,7 & 0,0 & 0,0 \\
\hline Phragmitetalia & 0,0 & 0,0 & 0,0 & 0,0 & 0,0 & 0,0 & 0,0 & 0,0 \\
\hline Phragmition & 0,1 & 0,0 & 0,0 & 0,0 & 0,0 & 0,0 & 0,0 & 0,0 \\
\hline Phragmitetalia s. 1. & 0,1 & 0,0 & 0,0 & 0,0 & 0,0 & 0,0 & 0,0 & 0,0 \\
\hline Nasturtio-Glycerietalia & 0,0 & 0,0 & 0,0 & 0,0 & 0,0 & 0,0 & 0,0 & 0,0 \\
\hline Glycerio-Sparganion & 0,3 & 0,2 & 0,0 & 0,0 & 0,0 & 0,0 & 0,0 & 0,0 \\
\hline Nasturtio-Glycerietalia s. 1. & 0,3 & 0,2 & 0,0 & 0,0 & 0,0 & 0,0 & 0,0 & 0,0 \\
\hline Magnocaricetalia & 0,0 & 0,0 & 0,0 & 0,0 & 0,0 & 0,0 & 0,0 & 0,0 \\
\hline Magnocaricion & 2,6 & 0,6 & 0,2 & 0,1 & 1,9 & 0,1 & 0,0 & 0,0 \\
\hline Caricenion rostratae & 0,9 & 0,0 & 0,0 & 0,0 & 0,1 & 0,0 & 0,0 & 0,0 \\
\hline Caricenion gracilis & 1,3 & 0,0 & 0,0 & 0,0 & 0,6 & 0,0 & 0,0 & 0,0 \\
\hline Magnocaricion s. 1. & 4,8 & 0,6 & 0,2 & 0,1 & 2,6 & 0,1 & 0,0 & 0,0 \\
\hline Magnocaricetalia s. 1. & 4,8 & 0,6 & 0,2 & 0,1 & 2,6 & 0,1 & 0,0 & 0,0 \\
\hline Phragmitetea s. 1. & 16,1 & 4,5 & 0,7 & 0,2 & 8,7 & 0,8 & 0,0 & 0,0 \\
\hline Isoëto-Nanojuncetea & 0,0 & 0,0 & 0,0 & 0,0 & 0,0 & 0,0 & 0,0 & 0,0 \\
\hline Nanocyperetalia & 0,0 & 0,0 & 0,0 & 0,0 & 0,0 & 0,0 & 0,0 & 0,0 \\
\hline Nanocyperion flavescentis & 1,3 & 0,1 & 0,0 & 0,0 & 1,1 & 0,0 & 0,0 & 0,0 \\
\hline Nanocyperetalia s. 1. & 0,0 & 0,0 & 0,0 & 0,0 & 0,0 & 0,0 & 0,0 & 0,0 \\
\hline Isoëto-Nanojuncetea s. 1 . & 1,3 & 0,1 & 0,0 & 0,0 & 1,1 & 0,0 & 0,0 & 0,0 \\
\hline Montio-Cardaminetea & 0,0 & 0,0 & 0,0 & 0,0 & 0,0 & 0,0 & 0,0 & 0,0 \\
\hline Montio-Cardaminetalia & 0,0 & 0,0 & 0,0 & 0,0 & 0,0 & 0,0 & 0,0 & 0,0 \\
\hline Cardamini-Montion & 0,1 & 0,0 & 0,0 & 0,0 & 0,0 & 0,0 & 0,0 & 0,0 \\
\hline
\end{tabular}


(6. táblázat folytatása. Table 6 continued.)

\begin{tabular}{|c|c|c|c|c|c|c|c|c|}
\hline & \multicolumn{4}{|c|}{ Csoportrészesedés } & \multicolumn{4}{|c|}{ Csoporttömeg } \\
\hline & $\mathrm{Sa}$ & $\mathrm{Pa}$ & Upa & Utp & Sa & $\mathrm{Pa}$ & Upa & Utp \\
\hline Montio-Cardaminetalia s. 1. & 0,1 & 0,0 & 0,0 & 0,0 & 0,0 & 0,0 & 0,0 & 0,0 \\
\hline Montio-Cardaminetea s. 1. & 0,1 & 0,0 & 0,0 & 0,0 & 0,0 & 0,0 & 0,0 & 0,0 \\
\hline Cypero-Phragmitea s. 1. & 17,5 & 4,6 & 0,8 & 0,2 & 9,8 & 0,8 & 0,0 & 0,0 \\
\hline Oxycocco-Caricea nigrae & 0,0 & 0,0 & 0,0 & 0,0 & 0,0 & 0,0 & 0,0 & 0,0 \\
\hline Scheuchzerio-Caricetea nigrae & 0,0 & 0,0 & 0,0 & 0,0 & 0,0 & 0,0 & 0,0 & 0,0 \\
\hline Scheuchzerio-Caricetalia nigrae & 0,3 & 0,0 & 0,0 & 0,0 & 0,1 & 0,0 & 0,0 & 0,0 \\
\hline Scheuchzerio-Caricetea nigrae s. 1. & 0,3 & 0,0 & 0,0 & 0,0 & 0,1 & 0,0 & 0,0 & 0,0 \\
\hline Oxycocco-Caricea nigrae s. 1. & 0,3 & 0,0 & 0,0 & 0,0 & 0,1 & 0,0 & 0,0 & 0,0 \\
\hline Molinio-Arrhenatherea & 1,6 & 1,2 & 0,8 & 1,1 & 0,5 & 0,7 & 0,1 & 0,1 \\
\hline Molinio-Juncetea & 4,2 & 1,2 & 0,3 & 0,1 & 3,0 & 0,1 & 0,0 & 0,0 \\
\hline Molinietalia coeruleae & 1,9 & 0,7 & 0,3 & 0,5 & 0,4 & 0,1 & 0,0 & 0,0 \\
\hline Deschampsion caespitosae & 3,0 & 1,2 & 0,1 & 0,0 & 2,4 & 0,3 & 0,0 & 0,0 \\
\hline Filipendulo-Cirsion oleracei & 0,4 & 0,1 & 0,2 & 0,2 & 0,0 & 0,0 & 0,0 & 0,0 \\
\hline Alopecurion pratensis & 0,4 & 0,2 & 0,0 & 0,0 & 3,5 & 0,0 & 0,0 & 0,0 \\
\hline Molinietalia coeruleae s. 1 . & 5,7 & 2,2 & 0,6 & 0,7 & 6,3 & 0,4 & 0,0 & 0,0 \\
\hline Molinio-Juncetea s. 1. & 9,9 & 3,4 & 0,9 & 0,8 & 9,3 & 0,5 & 0,0 & 0,0 \\
\hline Arrhenatheretea & 0,0 & 0,0 & 0,0 & 0,0 & 0,0 & 0,0 & 0,0 & 0,0 \\
\hline Arrhenatheretalia & 0,0 & 0,2 & 0,3 & 0,3 & 9,8 & 1,2 & 0,0 & 0,0 \\
\hline Arrhenatheretea s. 1. & 0,0 & 0,2 & 0,3 & 0,3 & 0,0 & 0,0 & 0,0 & 0,0 \\
\hline Molinio-Arrhenatherea s. 1. & 11,5 & 4,8 & 2,0 & 2,2 & 0,0 & 0,0 & 0,1 & 0,1 \\
\hline Puccinellio-Salicornea & 0,0 & 0,0 & 0,0 & 0,0 & 0,0 & 0,0 & 0,0 & 0,0 \\
\hline Festuco-Puccinellietea & 0,7 & 0,4 & 0,1 & 0,0 & 0,1 & 0,0 & 0,0 & 0,0 \\
\hline Festuco-Puccinellietalia & 0,4 & 0,1 & 0,0 & 0,0 & 1,1 & 0,0 & 0,0 & 0,0 \\
\hline Festuco-Puccinellietea s. 1. & 1,1 & 0,5 & 0,1 & 0,0 & 1,2 & 0,0 & 0,0 & 0,0 \\
\hline Puccinellio-Salicornea s. 1. & 1,1 & 0,5 & 0,1 & 0,0 & 1,2 & 0,0 & 0,0 & 0,0 \\
\hline Festuco-Bromea & 0,0 & 0,1 & 0,0 & 0,0 & 0,0 & 0,0 & 0,0 & 0,0 \\
\hline Festuco-Brometea & 0,0 & 0,1 & 0,0 & 0,1 & 0,0 & 0,0 & 0,0 & 0,0 \\
\hline Festucetalia valesiacae & 0,0 & 0,0 & 0,0 & 0,0 & 0,0 & 0,0 & 0,0 & 0,0 \\
\hline Festucion rupicolae & 0,0 & 0,0 & 0,0 & 0,0 & 0,0 & 0,0 & 0,0 & 0,0 \\
\hline Cynodonto-Festucenion & 0,1 & 0,0 & 0,0 & 0,0 & 0,0 & 0,0 & 0,0 & 0,0 \\
\hline Festucion rupicolae s. 1. & 0,1 & 0,0 & 0,0 & 0,0 & 0,0 & 0,0 & 0,0 & 0,0 \\
\hline Festucetalia valesiacae s. 1 . & 0,1 & 0,0 & 0,0 & 0,0 & 0,0 & 0,0 & 0,0 & 0,0 \\
\hline Festuco-Brometea s. 1. & 0,1 & 0,1 & 0,0 & 0,1 & 0,0 & 0,0 & 0,0 & 0,0 \\
\hline Festuco-Bromea s. 1. & 0,1 & 0,2 & 0,0 & 0,1 & 0,0 & 0,0 & 0,0 & 0,0 \\
\hline Chenopodio-Scleranthea & 1,0 & 0,5 & 0,1 & 0,0 & 0,1 & 0,1 & 0,0 & 0,0 \\
\hline Secalietea & 1,2 & 0,7 & 0,5 & 0,4 & 0,3 & 0,2 & 0,1 & 0,0 \\
\hline Chenopodietea & 0,1 & 1,3 & 0,5 & 0,3 & 0,0 & 0,1 & 0,0 & 0,0 \\
\hline Sisymbrietalia & 0,0 & 0,0 & 0,0 & 0,0 & 0,0 & 0,0 & 0,0 & 0,0 \\
\hline Sisymbrion officinalis & 0,0 & 0,1 & 0,0 & 0,0 & 0,0 & 0,0 & 0,0 & 0,0 \\
\hline
\end{tabular}


Kevey B.

(6. táblázat folytatása. Table 6 continued.)

\begin{tabular}{|c|c|c|c|c|c|c|c|c|}
\hline & \multicolumn{4}{|c|}{ Csoportrészesedés } & \multicolumn{4}{|c|}{ Csoporttömeg } \\
\hline & Sa & $\mathrm{Pa}$ & Upa & Utp & $\mathrm{Sa}$ & $\mathrm{Pa}$ & Upa & Utp \\
\hline Sisymbrietalia s. 1. & 0,0 & 0,1 & 0,0 & 0,0 & 0,0 & 0,0 & 0,0 & 0,0 \\
\hline Chenopodietea s. 1. & 0,1 & 1,4 & 0,5 & 0,3 & 0,0 & 0,1 & 0,0 & 0,0 \\
\hline Artemisietea & 0,0 & 0,0 & 0,0 & 0,0 & 0,0 & 0,0 & 0,0 & 0,0 \\
\hline Artemisietalia & 0,0 & 0,0 & 0,0 & 0,0 & 0,0 & 0,0 & 0,0 & 0,0 \\
\hline Arction lappae & 0,5 & 1,1 & 0,6 & 0,6 & 0,3 & 1,4 & 0,1 & 0,1 \\
\hline Artemisietalia s. 1. & 0,5 & 1,1 & 0,6 & 0,6 & 0,3 & 1,4 & 0,1 & 0,1 \\
\hline Artemisietea s. 1. & 0,5 & 1,1 & 0,6 & 0,6 & 0,3 & 1,4 & 0,1 & 0,1 \\
\hline Galio-Urticetea & 0,0 & 0,0 & 0,0 & 0,0 & 0,0 & 0,0 & 0,0 & 0,0 \\
\hline Calystegietalia sepium & 0,0 & 0,0 & 0,0 & 0,0 & 0,0 & 0,0 & 0,0 & 0,0 \\
\hline Galio-Alliarion & 0,5 & 2,5 & 1,6 & 0,9 & 0,3 & 1,6 & 0,7 & 0,3 \\
\hline Calystegion sepium & 6,9 & 7,2 & 2,4 & 2,0 & 13,7 & 1,7 & 0,8 & 0,4 \\
\hline Calystegietalia sepium s. 1 . & 7,4 & 9,7 & 4,0 & 2,9 & 14,0 & 3,3 & 1,5 & 0,7 \\
\hline Galio-Urticetea s. 1. & 7,4 & 9,7 & 4,0 & 2,9 & 14,0 & 3,3 & 1,5 & 0,7 \\
\hline Bidentetea & 0,0 & 0,0 & 0,0 & 0,0 & 0,0 & 0,0 & 0,0 & 0,0 \\
\hline Bidentetalia & 4,7 & 1,5 & 0,3 & 0,3 & 5,2 & 0,2 & 0,0 & 0,0 \\
\hline Bidention tripartiti & 1,4 & 0,2 & 0,0 & 0,0 & 4,6 & 0,0 & 0,0 & 0,0 \\
\hline Bidentetalia s. 1. & 6,1 & 1,7 & 0,3 & 0,3 & 9,8 & 0,2 & 0,0 & 0,0 \\
\hline Bidentetea s. 1. & 6,1 & 1,7 & 0,3 & 0,3 & 9,8 & 0,2 & 0,0 & 0,0 \\
\hline Plantaginetea & 0,0 & 0,0 & 0,0 & 0,0 & 0,0 & 0,0 & 0,0 & 0,0 \\
\hline Plantaginetalia majoris & 1,8 & 1,2 & 0,3 & 0,3 & 1,4 & 0,1 & 0,0 & 0,0 \\
\hline Agropyro-Rumicion crispi & 0,1 & 0,1 & 0,0 & 0,0 & 0,0 & 0,0 & 0,0 & 0,0 \\
\hline Plantaginetalia majoris s. 1. & 1,9 & 1,3 & 0,3 & 0,3 & 1,4 & 0,1 & 0,0 & 0,0 \\
\hline Plantaginetea s. 1. & 1,9 & 1,3 & 0,3 & 0,3 & 1,4 & 0,1 & 0,0 & 0,0 \\
\hline Epilobietea angustifolii & 0,0 & 0,0 & 0,0 & 0,0 & 0,0 & 0,0 & 0,0 & 0,0 \\
\hline Epilobietalia & 1,8 & 5,2 & 3,5 & 3,2 & 0,4 & 2,0 & 1,7 & 0,9 \\
\hline Epilobion angustifolii & 0,0 & 0,0 & 0,2 & 0,2 & 0,0 & 0,0 & 0,0 & 0,0 \\
\hline Epilobietalia s. 1. & 1,8 & 5,2 & 3,7 & 3,4 & 0,4 & 2,0 & 1,7 & 0,9 \\
\hline Epilobietea angustifolii s. 1 . & 1,8 & 5,2 & 3,7 & 3,4 & 0,4 & 2,0 & 1,7 & 0,9 \\
\hline Urtico-Sambucetea & 0,0 & 0,0 & 0,0 & 0,0 & 0,0 & 0,0 & 0,0 & 0,0 \\
\hline Sambucetalia & 0,0 & 0,0 & 0,0 & 0,0 & 0,0 & 0,0 & 0,0 & 0,0 \\
\hline Sambuco-Salicion capreae & 0,0 & 0,4 & 0,4 & 0,3 & 0,0 & 0,0 & 1,2 & 0,5 \\
\hline Sambucetalia s. 1. & 0,0 & 0,4 & 0,4 & 0,3 & 0,0 & 0,0 & 1,2 & 0,5 \\
\hline Urtico-Sambucetea s. 1. & 0,0 & 0,4 & 0,4 & 0,3 & 0,0 & 0,0 & 1,2 & 0,5 \\
\hline Chenopodio-Scleranthea s. 1 . & 20,0 & 22,0 & 10,4 & 8,5 & 26,3 & 7,4 & 4,6 & 2,2 \\
\hline Indifferens & 5,1 & 3,6 & 2,1 & 1,8 & 1,3 & 3,7 & 1,8 & 0,7 \\
\hline Adventiva & 5,1 & 8,8 & 6,7 & 5,8 & 1,9 & 9,6 & 2,2 & 1,4 \\
\hline
\end{tabular}

Sa: Leucojo aestivi-Salicetum albae, Szigetköz (Kevey 2008: 25 felv.); Pa: Senecioni sarracenici-Populetum albae, Szigetköz (Kevey 2008: 25 felv.); Upa: Pimpinello majoris-Ulmetum populosum albae, Szigetköz (Kever 2008: 4 felv.; Kevey ined.: 21 felv.); Utp: Pimpinello majoris-Ulmetum typicum, Szigetköz (Kever 2008: 15 felv.; Kevey ined.: 10 felv.) 
Puha- és keményfás ligeterdők a Szigetközben

7. táblázat. Fűzligetek és fehérnyár-ligetek differenciális fajai. Table 7. Differentiating species of Leucojo aestivi-Salicetum purpureae and Senecioni sarracenici-Populetum albae

\begin{tabular}{|c|c|c|c|c|c|}
\hline & $\mathrm{Sa}$ & $\mathrm{Pa}$ & & $\mathrm{Sa}$ & $\mathrm{Pa}$ \\
\hline Konstans fajok & & & Szubkonstans fajok & & \\
\hline Carex vesicaria & $\mathrm{V}$ & - & Persicaria minor & IV & - \\
\hline Leucojum aestivum & $\mathrm{V}$ & - & Scutellaria galericulata & IV & - \\
\hline Myosotis nemorosa & $\mathrm{V}$ & - & Salix fragilis & IV & I \\
\hline Persicaria hydropiper & $\mathrm{V}$ & - & Equisetum arvense & IV & II \\
\hline Rorippa amphibia & $\mathrm{V}$ & - & Alliaria petiolata & - & IV \\
\hline Rorippa palustris & $\mathrm{V}$ & - & Brachypodium sylvaticum & - & IV \\
\hline Sium latifolium & $\mathrm{V}$ & - & Galanthus nivalis & - & IV \\
\hline Bidens tripartita & $\mathrm{V}$ & I & Scilla vindobonensis & - & IV \\
\hline Cardamine pratensis & $\mathrm{V}$ & I & Alnus incana & I & IV \\
\hline Carex acuta & $\mathrm{V}$ & I & Arctium lappa & I & IV \\
\hline Carex riparia & $\mathrm{V}$ & I & Circaea lutetiana & I & IV \\
\hline Galium palustre & $\mathrm{V}$ & I & Populus $\times$ euramericana & I & IV \\
\hline Iris pseudacorus & $\mathrm{V}$ & I & Sambucus nigra & I & IV \\
\hline Lysimachia vulgaris & $\mathrm{V}$ & I & Scrophularia nodosa & I & IV \\
\hline Lythrum salicaria & $\mathrm{V}$ & I & Akcesszórikus fajok & & \\
\hline Mentha arvensis & $\mathrm{V}$ & I & Alisma plantago-aquatica & III & - \\
\hline Stachys palustris & $\mathrm{V}$ & I & Barbarea stricta & III & - \\
\hline Lycopus europaeus & $\mathrm{V}$ & II & Rumex hydrolapathum & III & - \\
\hline Lysimachia nummularia & $\mathrm{V}$ & II & Arctium minus & - & III \\
\hline Persicaria dubia & $\mathrm{V}$ & III & Cucubalus baccifer & - & III \\
\hline Phragmites australis & $\mathrm{V}$ & III & Lapsana communis & - & III \\
\hline Ranunculus repens & $\mathrm{V}$ & III & Rumex sanguineus & - & III \\
\hline Solanum dulcamara & $\mathrm{V}$ & III & Symphytum tuberosum & - & III \\
\hline Aegopodium podagraria & - & $\mathrm{V}$ & Elymus caninus & I & III \\
\hline Euonymus europaeus & - & $\mathrm{V}$ & Quercus robur & I & III \\
\hline Lamium maculatum & - & $\mathrm{V}$ & Stachys sylvatica & I & III \\
\hline Carduus crispus & I & $\mathrm{V}$ & Ulmus minor & I & III \\
\hline Cornus sanguinea & I & $\mathrm{V}$ & Szubaccesszórikus fajok & & \\
\hline Crataegus monogyna & I & $\mathrm{V}$ & Caltha palustris & II & - \\
\hline Festuca gigantea & I & $\mathrm{V}$ & Carex elata & II & - \\
\hline Impatiens parviflora & I & $\mathrm{V}$ & Epilobium lanceolatum & II & - \\
\hline Populus alba & I & $\mathrm{V}$ & Ranunculus sceleratus & II & - \\
\hline Senecio sarracenicus & I & $\mathrm{V}$ & Rorippa sylvestris & II & - \\
\hline Galeopsis bifida & II & $\mathrm{V}$ & Senecio paludosus & II & - \\
\hline Glechoma hederacea & II & $\mathrm{V}$ & Aethusa cynapium & - & II \\
\hline Humulus lupulus & II & $\mathrm{V}$ & Clematis vitalba & - & II \\
\hline Myosoton aquaticum & II & $\mathrm{V}$ & Dactylis glomerata & - & II \\
\hline Galium aparine & III & $\mathrm{V}$ & Polygonatum latifolium & - & II \\
\hline Impatiens glandulifera & III & $\mathrm{V}$ & Ribes rubrum & - & II \\
\hline Ranunculus ficaria & III & $\mathrm{V}$ & Differenciális fajok száma & 36 & 44 \\
\hline
\end{tabular}

Sa: Leucojo aestivi-Salicetum albae, Szigetköz (KeVey 2008: 25 felv.); Pa: Senecioni sarraceniciPopuletum albae, Szigetköz (Kevey 2008: 25 felv.) 
Kevey B.

8. táblázat. Fehérnyár-ligetek és tölgy-kőris-szil ligetek fehér nyáras konszociációjának differenciális fajai. Table 8. Differentiating species of Senecioni sarracenici-Populetum albae and Pimpinello majoris-Ulmetum populosum albae

\begin{tabular}{|c|c|c|c|c|c|}
\hline & $\mathrm{Pa}$ & Upa & & $\mathrm{Pa}$ & Upa \\
\hline Konstans fajok & & & Viola mirabilis & - & IV \\
\hline Galeopsis bifida & $\mathrm{V}$ & - & Convallaria majalis & I & IV \\
\hline Impatiens glandulifera & $\mathrm{V}$ & - & Heracleum sphondylium & I & IV \\
\hline Poapalustris & $\mathrm{V}$ & - & Lathraea squamaria & I & IV \\
\hline Senecio sarracenicus & $\mathrm{V}$ & - & Ligustrum vulgare & I & IV \\
\hline Glechoma hederacea & $\mathrm{V}$ & I & Parietaria officinalis & I & IV \\
\hline Myosoton aquaticum & $\mathrm{V}$ & I & Robinia pseudo-acacia & I & IV \\
\hline Phalaris arundinacea & $\mathrm{V}$ & I & Clematis vitalba & II & IV \\
\hline Poa trivialis & $\mathrm{V}$ & I & Akcesszórikus fajok & & \\
\hline Festuca gigantea & $\mathrm{V}$ & II & Agrostis stolonifera & III & - \\
\hline Impatiens noli-tangere & $\mathrm{V}$ & II & Persicaria dubia & III & - \\
\hline Lamium maculatum & $\mathrm{V}$ & II & Ranunculus repens & III & - \\
\hline Symphytum officinale & $\mathrm{V}$ & II & Rumex sanguineus & III & - \\
\hline Urtica dioica & $\mathrm{V}$ & III & Elymus caninus & III & I \\
\hline Anemone ranunculoides & - & $\mathrm{V}$ & Phragmites australis & III & II \\
\hline Corylus avellana & - & $\mathrm{V}$ & Solanum dulcamara & III & $\mathrm{I}$ \\
\hline Galium odoratum & - & $\mathrm{V}$ & Acerpseudo-platanus & - & III \\
\hline Juglans regia & - & $\mathrm{V}$ & Arum maculatum & - & III \\
\hline Acer campestre & I & $\mathrm{V}$ & Polygonatum multiflorum & - & III \\
\hline Allium ursinum & I & $\mathrm{V}$ & Pulmonaria officinalis & - & III \\
\hline Fraxinus excelsior & I & $\mathrm{V}$ & Rhamnus catharticus & - & III \\
\hline Gagea lutea & I & $\mathrm{V}$ & Vicia dumetorum & - & III \\
\hline Paris quadrifolia & I & $\mathrm{V}$ & Geum urbanum & I & III \\
\hline Viola suavis s. 1. & I & $\mathrm{V}$ & Pimpinella major & I & III \\
\hline Padus avium & II & $\mathrm{V}$ & Viburnum opulus & I & III \\
\hline Polygonatum latifolium & II & $\mathrm{V}$ & Viola reichenbachiana & I & III \\
\hline Ulmus laevis & II & $\mathrm{V}$ & Szubaccesszórikus fajok & & \\
\hline Solidago gigantea & III & $\mathrm{V}$ & Carex remota & II & - \\
\hline Stachys sylvatica & III & $\mathrm{V}$ & Dactylis glomerata & II & - \\
\hline Ulmus minor & III & $\mathrm{V}$ & Lysimachia nummularia & II & - \\
\hline Szubkonstans fajok & & & Arum orientale & - & II \\
\hline Arctium lappa & IV & - & Berberis vulgaris & - & II \\
\hline Aster novi-belgii agg. & IV & - & Campanula trachelium & - & II \\
\hline Calystegia sepium & IV & I & Carex sylvatica & - & II \\
\hline Populus $\times$ euramericana & IV & I & Frangula alnus & - & II \\
\hline Rumex obtusifolius & IV & I & Galeopsis speciosa & - & II \\
\hline Salix alba & IV & I & Geranium robertianum & - & II \\
\hline Alliaria petiolata & IV & II & Lonicera xylosteum & - & II \\
\hline Angelica sylvestris & IV & II & Malus sylvestris & - & II \\
\hline Scrophularia nodosa & IV & II & Ulmus glabra & - & II \\
\hline Melica nutans & - & IV & Viola odorata & - & II \\
\hline Physalis alkekengi & - & IV & Differenciális fajok száma & 32 & 47 \\
\hline
\end{tabular}

Pa: Senecioni sarracenici-Populetum albae, Szigetköz (Kevey 2008: 25 felv.); Upa: Pimpinello majoris-Ulmetum populosum albae, Szigetköz (Kevey 2008: 4 felv.; Kevey ined.: 21 felv.) 
9. táblázat. Tölgy-kőris-szil ligetek fehér nyáras konszociációinak és tipikus állományainak differenciális fajai

Table 9. Differentiating species of Pimpinello majoris-Ulmetum populosum albae and Pimpinello majoris-Ulmetum typicum

\begin{tabular}{lcc}
\hline & Upa & Utp \\
\hline Konstans fajok & & V \\
$\begin{array}{l}\text { Polygonatum multiflorum } \\
\text { Szubkonstans fajok }\end{array}$ & III & II \\
Alnus incana & IV & II \\
Impatiens parviflora & IV & IV \\
Campanula trachelium & II & \\
Akcesszórikus fajok & & III \\
Ailanthus altissima & I & III \\
Cornus mas & I & III \\
Corydalis cava & I & III \\
Hedera helix & I & \\
Szubakcesszórikus fajok & & II \\
Veronica hederifolia subsp. lucorum & - & 7 \\
Differenciális fajok száma & 2 & .
\end{tabular}

Upa: Pimpinello majoris-Ulmetum populosum albae, Szigetköz (Kevey 2008: 4 felv.; Kevey ined.: 21 felv.); Utp: Pimpinello majoris-Ulmetum typicum, Szigetköz (Kevey 2008: 15 felv.; Kevey ined.: 10 felv.) 